\title{
ANDRÉ LUÍS INOCENCIO
}

\section{PURIFICAÇÃO E CARACTERIZAÇÃO DO FRAGMENTO FAB ANTI-DIGOXINA OBTIDO PELA TÉCNICA DE PHAGE DISPLAY}

Dissertação apresentada ao programa de Pós-Graduação Interunidades em Biotecnologia USP/Instituto Butantan/IPT, para a obtenção do Título de Mestre em Biotecnologia. 


\section{PURIFICAÇÃO E CARACTERIZAÇÃO DO FRAGMENTO FAB ANTI-DIGOXINA OBTIDO PELA TÉCNICA DE PHAGE DISPLAY}

Dissertação apresentada ao programa de Pós-Graduação Interunidades em Biotecnologia USP/Instituto Butantan/IPT, para a obtenção do Título de Mestre em Biotecnologia.

Área de concentração: Biotecnologia

Orientadora: Dra. Ana Maria Moro Co-orientadora: Dra. Lilian Rumi Tsuruta

Versão corrigida. A versão original eletrônica encontra-se disponível tanto na Biblioteca do ICB quanto na Biblioteca de Teses e Dissertações da USP (BDTD) 
DADOS DE CATALOGAÇÃO NA PUBLICAÇÃO (CIP)

Serviço de Biblioteca e Informação Biomédica do

Instituto de Ciências Biomédicas da Universidade de São Paulo

reprodução não autorizada pelo autor

Inocencio, André Luís.

Purificação e caracterização do fragmento Fab anti-digoxina obtido pela técnica de phage display / André Luís Inocencio. -- São Paulo, 2016.

Orientador: Profa. Dra. Ana Maria Moro.

Dissertação (Mestrado) - Universidade de São Paulo. Instituto de Ciências Biomédicas. Programa de Pós-Graduação Interunidades em Biotecnologia USP/IPT/Instituto Butantan. Área de concentração:

Biotecnologia. Linha de pesquisa: Anticorpos monoclonais.

Versão do título para o inglês: Purification and characterization of anti-digoxin Fab fragments by phage display technology.

1. Digitálicos 2 . Cromatografia 3 . Fragmento Fab monoclonal 4. Phage display 5. Digoxina 6 . Ressonância plasmonica de superfície I. Moro, Profa. Ana Maria II. Universidade de São Paulo. Instituto de Ciências Biomédicas. Programa de Pós-Graduação Interunidades em Biotecnologia USP/IPT/Instituto Butantan III. Título. 
Candidato(a):

Titulo da Dissertação:

Orientador(a):
André Luis Inocencio.

Purificaçăo e caracterizaçăo do fragmento Fab anti-digoxina obtido pela técnica de phage display.

Profa. Dra. Ana Maria Moro.

A Comissăo Julgadora dos trabalhos de Defesa da Dissertação de Mestrado,

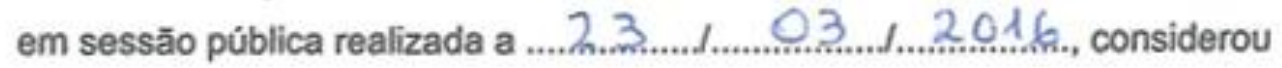
( $)$ Aprovado(a)
( ) Reprovado(a)

Examinador(a): Assinatura: .......mend Fosmandes. Nome: ............E. E...........R.A.ANDE.S Instituiçăo: .......N.S.T.IT.T.T. B........A.N.T.A.R.

Examinador(a): Assinatura: ENdAs de LAdulio

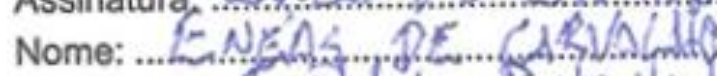
Instituiçăo: ... Ins.s. f.

Presidente:

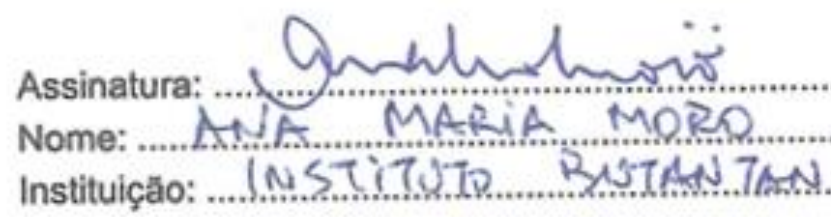




\section{COMISSÃO DE ÉTICA NO USO DE ANIMAIS \\ INSTITUTO BUTANTAN}

Av. Vital Brazil, 1500, CEP 05503-900, São Paulo, SP, Brazil

Telefone: (55) (011) 2627-9585 - Fax: (55) (011) 2627-9505

ceuaib@butantan.gov.br

São Paulo, 14 de março de 2012.

Protocolo: I-1016/13

Dra. Ana Maria Moro

Laboratório de Biofármacos em Células Animais

Instituto Butantan

Referente Projeto: "Purificação e caracterização do fragmento Fab anti-digoxina obtido pela técnica de Phage Display".

A Comissão de Ética no Uso de Animais do Instituto Butantan (CEUAIB) informa que o projeto acima referido é isento de análise por parte desta Comissão, pois não faz uso de animais vertebrados em sua execução.

Cordialmente,

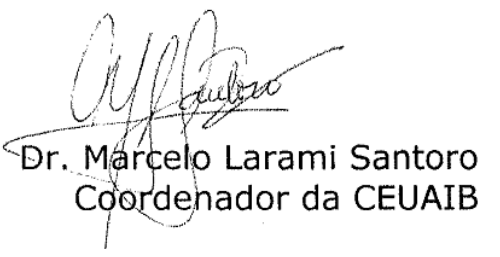




\section{AGRADECIMENTOS}

Ao meu filho Arthur, que sempre me recebia com um grande sorriso, quando chegava tarde, muitas vezes quase dormindo.

À Claudia por ser esta esposa maravilhosa e compreensiva.

Aos meus pais Eugely e Sandra pelo carinho e amor.

À Prof. Dra. Ana Maria Moro, pela orientação, confiança, por dividir seus conhecimentos e permitir que eu faça parte de sua equipe.

À Dra. Lilian Rumi Tsuruta pelos ensinamentos e ajuda na realização deste trabalho.

Ao Prof. Dr. Michael Philip Eddleston, Universidade de Edimburgo, por doar o fragmento Fab comercial - DigiFab ${ }^{\circledR}$, utilizado como referência nos ensaios.

Ao Dr. Wagner Quintilio, por todo o auxilio na elaboração das estratégias cromatográficas, por nossas discussões científicas e pela realização dos ensaios de SPR.

À Dra. Mariana Lopes dos Santos Curcio por todo o companheirismo e pela revisão da dissertação.

À Dra. Maria Teresa Alves Rodrigues pelos valiosos conselhos.

À Angélica Garbuio e à Roselaine Campos Targino, pelos ensinamentos e pela amizade.

Ao José Marcelino de Oliveira no suporte na realização das cromatografias.

À Monica Gomes de Oliveira e à Stephanie Murari do Nascimento pela ajuda na realização dos ensaios.

Aos amigos do Laboratório de Biofármacos em Células Animais: Caio César Irineu, Camila Maria Lucia da Silva, Carla Ploeger Mansueli, Cosminiana Silva Ferreira, Daniela Yumi Takata, Fatima Ap. Mendonça de Oliveira, José Ricardo de Almeida Ferreira, Maria José Alves da Silva, Mateus Dalcin Luchese, Priscila Mitsue Kayano Kushima, Rozelita Pereira do Nascimento, Silmara Ap. Vieira, Sônia de Fátima G. de Oliveira, Suzi Alcântara do Nascimento, na ajuda em diferentes áreas possibilitando a realização deste trabalho.

Aos amigos que passaram pelo laboratório, Mariana Costa Braga Schmidt, Elisa Emiko Oshiro, Eduardo Aliprandini e Viviane Midori Murata

À Dra. Ellisabeth Angelica Leme Martins e sua equipe (Dra. Elisabeth Cheng, Claudia, Erika e Juliano) por permitir a utilização de seus equipamentos. 


\section{RESUMO}

INOCENCIO, A. L. Purificação e caracterização do fragmento Fab anti-digoxina obtido pela técnica de phage display. 2016. 92 f. Dissertação (Mestrado em Biotecnologia) - Instituto de Ciências Biomédicas, Universidade de São Paulo, São Paulo, 2016.

A digoxina é um dos medicamentos indicados para o tratamento da insuficiência cardíaca. Possui janela terapêutica estreita, sendo responsável por casos de intoxicação. O único antídoto disponível para a desintoxicação é o anticorpo policlonal - DigiFab ${ }^{\circledR}$, no formato Fab. O seu uso é eficaz, porém de custo elevado. Clones bacterianos produtores de fragmento Fab monoclonal anti-digoxina foram obtidos previamente pelo nosso grupo, pela técnica de phage display. Neste trabalho as variantes Fab dos 4 clones foram expressas em E.coli para estabelecer o método para a purificação. Com a obtenção dos fragmentos Fab purificados, foi caracterizada a sua afinidade ao antígeno e especificidade, em ensaios de inibição por digoxina, digitoxina, digoxigenina e ouabaina. Os parâmetros cinéticos da ligação dos fragmentos Fab dos 4 clones e do DigiFab ${ }^{\circledR}$ foram avaliados por ressonância plasmônica de superfície. Nas condições experimentais, não foram verificadas diferenças significativas entre os produtos dos 4 clones e o comercial, demonstrando o potencial dos fragmentos Fab monoclonais obtidos como antídoto à digoxina.

Palavras-chave: Digitálicos. Cromatografia. Fragmento Fab monoclonal. Phage display. Digoxina. Ressonância plasmônica de superfície. 


\begin{abstract}
INOCENCIO, A. L. Purification and characterization of anti-digoxin Fab fragments obtained by phage display technology. 2016. 92 p. Masters thesis (Biotechnology) - Instituto de Ciências Biomédicas, Universidade de São Paulo, São Paulo, 2016.

Digoxin is a medication indicated for heart failure treatment. Its therapeutic window is narrow, being responsible for intoxication cases. The only antidote available for the detoxification is a polyclonal antibody - DigiFab ${ }^{\circledR}$ in Fab format. Its use is effective, but costly. Bacterial clones producing anti-digoxin monoclonal Fab fragments were previously obtained by our group using phage display technology. In this work the Fab variants of the 4 clones were expressed in E.coli to establish the purification method. The purified fragments were characterized regarding the affinity to the antigen and the specificity through inhibition assays with digoxin, digitoxin, digoxigenin and ouabain. The binding kinetic parameters of Fab fragments of the 4 clones and the commercial product to Dig-BSA conjugate were assessed by surface plasmon resonance. Under the experimental conditions no significant differences were observed among the 4 clones and the commercial product, demonstrating the potential of monoclonal Fab fragments as an antidote to digoxin.
\end{abstract}

Keywords: Digitalics. Chromatography. Monoclonal Fab fragment. Phage display. Digoxin. Surface plasmon resonance. 


\section{LISTA DE ILUSTRAÇÕES}

Figura 1 - Estrutura química da digoxina $\left(\mathrm{C}_{41} \mathrm{H}_{64} \mathrm{O}_{14}\right)$.

Figura 2 - Esquema da inibição da bomba de sódio/potássio pelos glicosídeos cardíacos. 17

Figura 3 - Estrutura da imunoglobulina da classe IgG. .22

Figura 4 - Resultados da digestão enzimática de anticorpos. 23

Figura 5 - Vetor fagomídeo pComb3XTT. .30

Figura 6 - Western blotting para verificação da presença dos fragmentos Fab antidigoxina no sobrenadante do cultivo celular, no periplasma e no sobrenadante do lisado bacteriano total.

Figura 7 - SDS-PAGE (12\%), corado por prata, das amostras que contém fragmento Fab anti-digoxina do clone 10.

Figura 8 - Avaliação da pureza do fragmento Fab anti-digoxina presente no sobrenadante da cultura de $E$. coli pela cromatografia em resina de afinidade Proteína G.

Figura 9 - SDS-PAGE (12\%) para avaliação da pureza dos fragmentos Fab antidigoxina expressos pelos 4 clones purificados. .50

Figura 10 - SDS-PAGE (12\%) corado por prata dos fragmentos Fab anti-digoxina purificados do sobrenadante e pela lise do periplasma.

Figura 11 - SDS PAGE (12\%) - Corado por prata. Estratégia 1 - Cromatografia em resina de proteína $\mathrm{G}$ seguida pela cromatografia de troca catiônica.

Figura 12 - SDS PAGE (12\%) - Corado por prata. Estratégia 2 - Cromatografia em resina de proteína $\mathrm{G}$ seguida pela cromatografia de troca catiônica. .55 Figura 13 - SDS PAGE (12\%) - Corado por prata. Estratégia 3 - Cromatografia de troca catiônica. .56

Figura 14 - SDS PAGE (12\%) - Corado por prata. Cromatografia de troca aniônica.

Figura 15 - SDS PAGE (12\%) - Coloração por prata. Cromatografia em resina de afinidade como segunda etapa cromatográfica após troca aniônica- alíquota 1 ......59 Figura 16 - SDS-PAGE (12\%) Coloração por prata. Cromatografia em resina de afinidade como segunda etapa cromatográfica após troca aniônica- alíquota 2. .....60 Figura 17 - SDS-PAGE (12\%) Corado por prata. Cromatografia em resina de troca catiônica, primeira etapa cromatográfica. 
Figura 18 - SDS-PAGE (12\%) Cromatografia de afinidade - segunda etapa cromatográfica - 1 .

Figura 19 - SDS-PAGE (12\%) Cromatografia de afinidade - segunda etapa cromatográfica -2 .

Figura 20 - Cromatogramas das purificações dos sobrenadantes dos 4 clones em coluna S Sepharose FF.

Figura 21 - Cromatogramas das purificações em resina de proteína $G$ das frações contendo os fragmentos Fab provenientes da cromatografia em coluna S Sepharose.

Figura 22 - SDS PAGE (12\%). Pureza dos fragmentos Fab anti-digoxina.

Figura 23 - Focalização isoelétrica em gel de poliacrilamida pH 3 a 10. Corado por prata.

Figura 24 - Avaliação da ligação entre os fragmentos Fab anti-digoxina à Dig-BSA e BSA.

Figura 25 - ELISA método 2 para avaliar o perfil de ligação entre os fragmentos Fab anti-digoxina à Dig-BSA e BSA.

Figura 26 - ELISA de inibição da ligação entre os fragmentos Fab anti-digoxina e a Dig-BSA pela digoxina. .71

Figura $27-\mathrm{IC}_{50}$ obtida pelo uso da digoxina como inibidor .72

Figura 28 - ELISA de inibição da ligação entre os fragmentos Fab anti-digoxina e a Dig-BSA pela digoxigenina .72

Figura $29-\mathrm{IC}_{50}$ obtida pelo uso da digoxigenina como inibidor. .73

Figura 30 - ELISA de inibição da ligação entre os fragmentos Fab anti-digoxina e a Dig-BSA pela digitoxina .74

Figura $31-\mathrm{IC}_{50}$ obtida pelo uso da digitoxina como inibidor. .75

Figura 32 - ELISA de inibição da ligação entre os fragmentos Fab anti-digoxina e a Dig-BSA pela ouabaína. .75

Figura $33-\mathrm{IC}_{50}$ obtida pelo uso da ouabaína como inibidor. .76

Figura 34 - Sensorgramas das titulações cinéticas. .77

Figura 35 - Velocidade de associação $\times$ velocidade de dissociação. .78

Figura 36 - Afinidade entre os fragmentos Fab dos 4 clones e DigiFab ${ }^{\circledR}$ com 0 conjugado Dig-BSA. 79 


\section{LISTA DE TABELAS}

Tabela 1 - Técnicas Cromatográficas e seus princípios. .25

Tabela 2 - Concentração inicial dos inibidores e fator de diluição seriada. 44

Tabela 3 - Concentração do fragmento Fab anti-digoxina do clone 10, obtida por ELISA, presente no sobrenadante da cultura de E. coli, periplasma e no lisado bacteriano total, a partir de $50 \mathrm{~mL}$ de cultura. 48

Tabela 4 - Balanço de massa dos fragmentos Fab anti-digoxina expressos pelos 4 clones, pré e pós purificação por cromatografia em resina de afinidade proteína G. 51 Tabela 5 - Rendimento obtido pela estratégia 1. .54

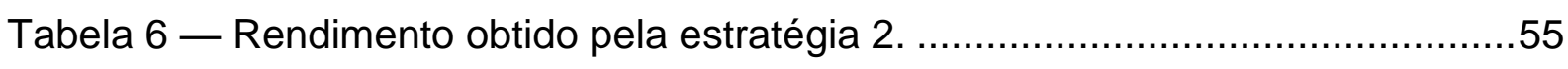

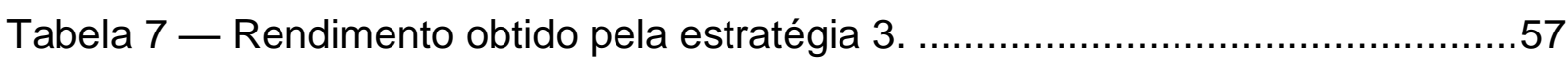

Tabela 8 - Balanço de massa dos fragmentos Fab dos 4 clones.............................66

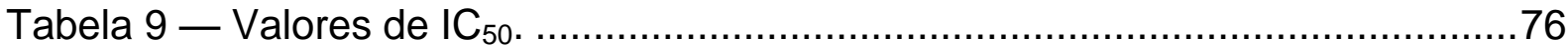

Tabela 10 — Parâmetros cinéticos obtidos por SPR ……………………….......79 


\section{LISTA DE ABREVIATURAS E SIGLAS}

\begin{tabular}{|c|c|}
\hline AcMo & - Anticorpo Monoclonal \\
\hline$a m p R$ & - resistência à ampicilina. \\
\hline ARBs & $\begin{array}{l}\text { - bloqueador de receptor da angiotensina (angiotensin receptor } \\
\text { blockers) }\end{array}$ \\
\hline BSA & - albumina do soro bovino (bovine serum albumin) \\
\hline cDNA & - DNA complementar (complementary DNA) \\
\hline CDR & $\begin{array}{l}\text { - regiões determinantes de complementariedade (complementarity } \\
\text { determining regions) }\end{array}$ \\
\hline $\mathrm{C}_{\mathrm{H}}$ & - região constante da cadeia pesada (constant heavy) \\
\hline $\mathrm{C}_{\mathrm{L}}$ & - região constante da cadeia leve (constant light) \\
\hline $\mathrm{DAB}$ & - 3,3' Diaminobenzidine tetrahydrochloride \\
\hline DIG & - Digoxin Investigation Group \\
\hline Dig-BSA & - digoxina conjugada a BSA \\
\hline DMSO & - dimetilsulfóxido \\
\hline $\mathrm{ECA}$ & - enzima conversora da angiotensina \\
\hline EDC & - hidrocloreto de 1-ethyl-3-(3-dimetilaminopropil) carbodiimida. \\
\hline EDTA & - ácido etilenodiamino tetra-acético (Ethylenediamine tetraacetic acid) \\
\hline ELISA & - Enzyme-linked immunosorbent assay \\
\hline Fab & - Fragmento de ligação ao antígeno (Fragment antigen binding) \\
\hline Fc & - Fragmento cristalizavel (Fragment crystallizable) \\
\hline FDA & - Food and Drug Administration \\
\hline $\mathrm{H}_{2} \mathrm{SO}_{4}$ & - ácido sulfúrico \\
\hline $\mathrm{HA}$ & - hemaglutininas \\
\hline $\mathrm{HC}$ & - cadeia pesada (heavy chain) \\
\hline His6 & - cauda contendo seis histidinas \\
\hline IEF & - isoelectric focusing electrophoresis \\
\hline $\lg$ & - imunoglobulina \\
\hline IPTG & 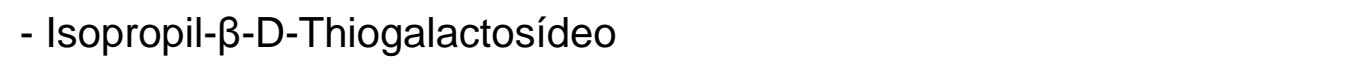 \\
\hline $\mathrm{k}_{\mathrm{a}}$ & - constante de associação \\
\hline K & stante de afinidade \\
\hline
\end{tabular}




\begin{tabular}{|c|c|}
\hline $\mathrm{k}_{\mathrm{d}}$ & - constante de dissociação \\
\hline $\mathrm{kDa}$ & - quilodalton \\
\hline LB & - Luria-Bertani \\
\hline LC & - cadeia leve (light chain) \\
\hline LMW & - marcador de baixo peso molecular (low molecular weight) \\
\hline MOPS & - Ácido 3-N-morfolinopropanossulfônico \\
\hline $\mathrm{NaCl}$ & - cloreto de sódio \\
\hline $\mathrm{NaOH}$ & - hidróxido de sódio \\
\hline NHS & - N-Hidroxisuccinimida \\
\hline ompA & - outer membrane protein \\
\hline PBS & - solução salina tamponada com fosfato (phosphate buffered saline) \\
\hline pelB & - pectate lyase $B$ \\
\hline $\mathrm{pl}$ & - ponto isoelétrico \\
\hline PROMISE & - prospective randomized milrinone survival evaluation \\
\hline PROVED & $\begin{array}{l}\text { - prospective randomized study of ventricular function and efficacy of } \\
\text { digoxin }\end{array}$ \\
\hline PVDF & - fluoreto de polivinilideno \\
\hline RADIANCE & $\begin{array}{l}\text { - randomized assessment of digoxin on inhibitors of the angiotensin } \\
\text { converting enzyme }\end{array}$ \\
\hline RENAME & - Relação Nacional de Medicamentos Essenciais \\
\hline SB & - Super Broth \\
\hline SDS-PAGE & $\begin{array}{l}\text { - eletroforese em gel de poliacrilamida com dodecil sulfato de sódio } \\
\text { (sodium dodecyl sulfate polyacrylamide gel electrophoresis) }\end{array}$ \\
\hline SPR & - ressonância plasmônica de superfície (surface plasmon resonance) \\
\hline SUS & - Sistema Único de Saúde \\
\hline TAG & - códon de terminação âmbar \\
\hline TMB & - 3,3',5,5'-tetrametilbenzidina \\
\hline $\mathrm{V}_{\mathrm{H}}$ & - região variável da cadeia pesada (heavy chain variable region) \\
\hline $\mathrm{V}_{\mathrm{L}}$ & - região variável da cadeia leve (light chain variable region) \\
\hline$\varepsilon$ & - coeficiente de absorção molar \\
\hline K & - kappa \\
\hline$\lambda$ & - lambda \\
\hline
\end{tabular}




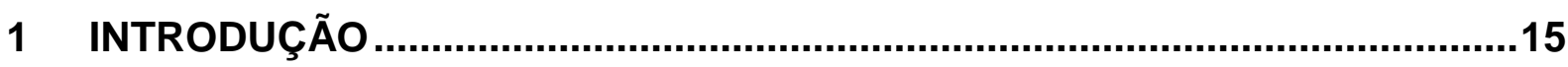

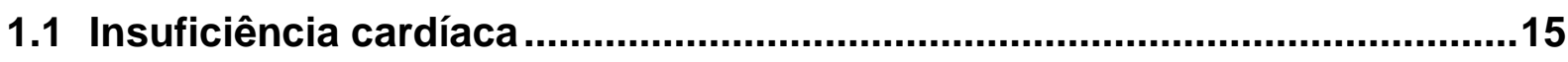

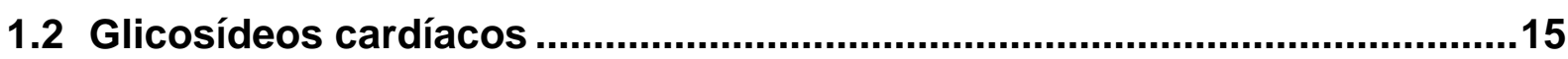

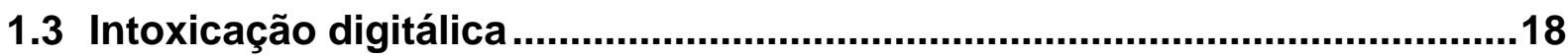

1.4 Cenário econômico para o fragmento Fab anti-digoxina ............................20

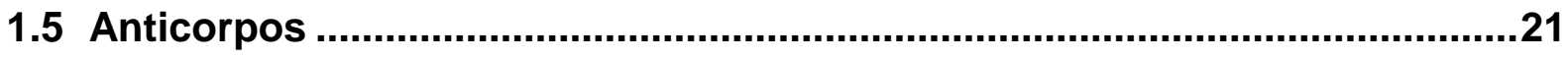

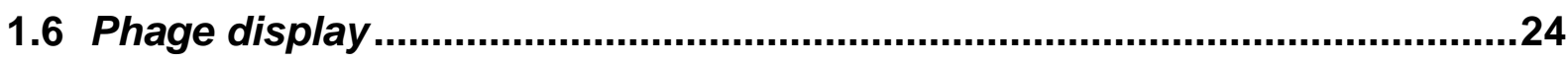

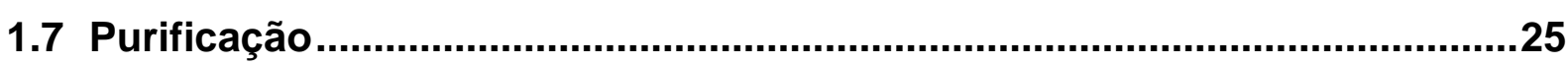

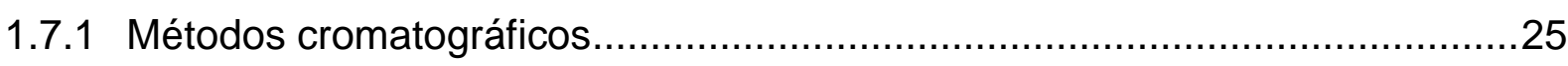

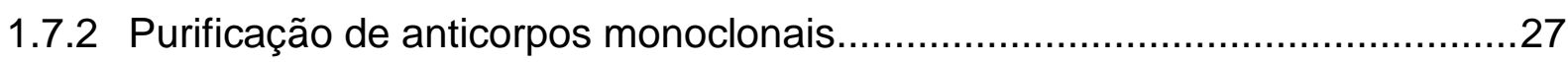

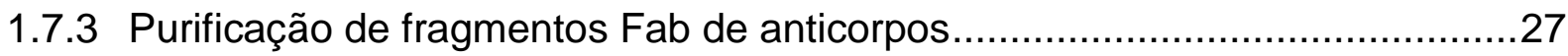

1.8 Obtenção dos fragmentos Fab monoclonal anti-digoxina ...........................28

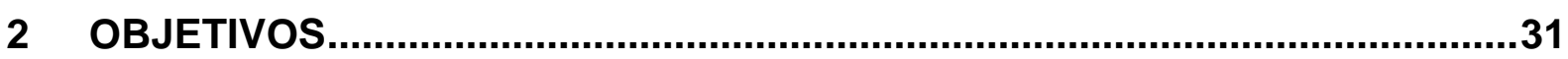

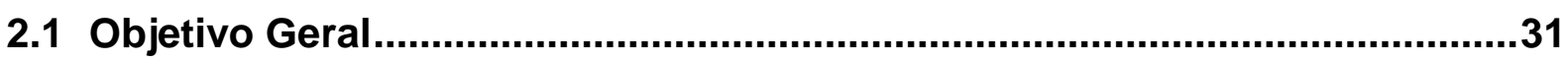

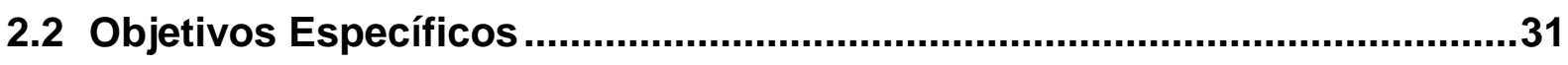

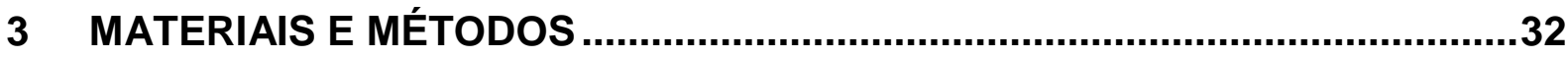

3.1 Linhagem bacteriana, meios, suplementos e soluções utilizadas nos

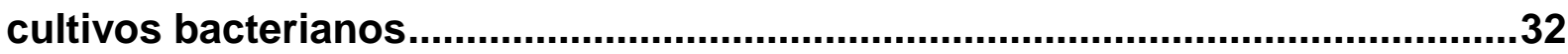

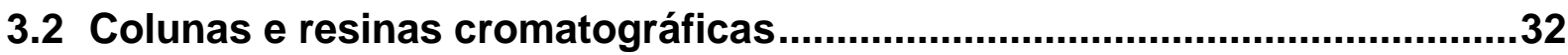

3.3 Soluções e materiais utilizados nos ensaios de caracterização ..................32

3.4 Anticorpos utilizados nos ensaios de caracterização …………….............33

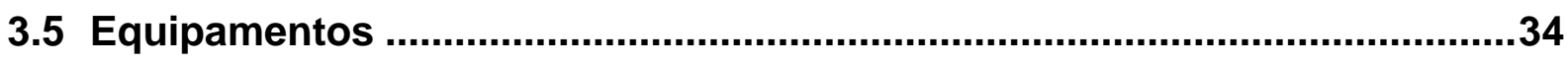

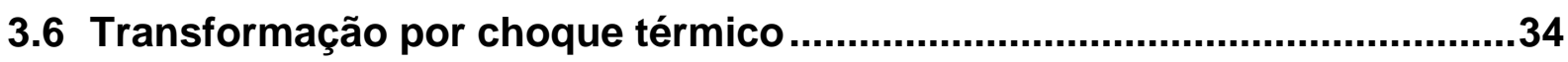

3.7 Expressão de fragmentos Fab anti-digoxina solúveis..................................35

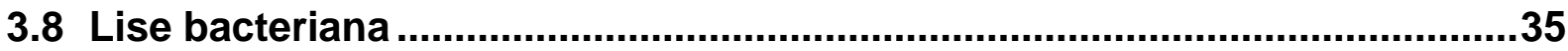

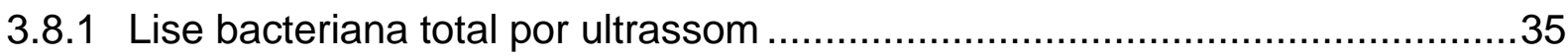

3.8.2 Lise do periplasma bacteriano por choque osmótico ....................................36

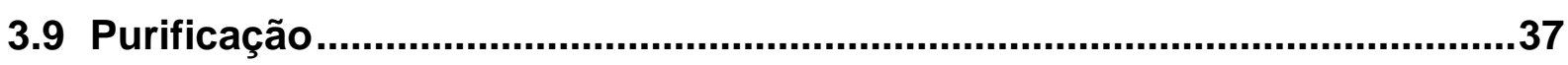

3.9.1 Cromatografia líquida em resina de afinidade Proteína $L$............................37

3.9.2 Cromatografia líquida em resina de afinidade Proteína G ..........................37

3.9.3 Ensaios de otimização da purificação dos fragmentos Fab anti-digoxina.......38 
3.10 Quantificação dos fragmentos Fab solúveis

3.10.1 Enzyme-linked immunosorbent assay (ELISA) - Método 1 …......................40

3.10.2 Dosagem de proteína pela Absorbância $280 \mathrm{~nm}$...................................... 41

3.10.3 Dosagem dos fragmentos Fab por ressonância plasmônica de superfície -

SPR

3.11 Ensaios analíticos

3.11.1 Eletroforese em gel de poliacrilamida com dodecil sulfato de sódio (SDS-

PAGE) . 42

3.11.2 Determinação do ponto isoelétrico …….................................................

3.11.3 Western Blotting

3.11.4 Ensaio de ligação dos clones Fab anti-digoxina ao antígeno pelo teste de

ELISA - Método 2 .43

3.11.5 ELISA de inibição da ligação entre os fragmentos anti-digoxina e a Dig-BSA pela digoxina e seus análogos - Método 3. .43

3.11.6 Determinação de parâmetros cinéticos por SPR . .45

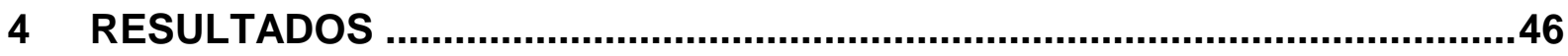

4.1 Expressão dos fragmentos Fab anti-digoxina em E. coli............................46

4.2 Avaliação da presença do fragmento Fab intracelular e no sobrenadante do cultivo bacteriano 46

4.3 Purificação dos fragmentos Fab anti-digoxina expressos em E. coli .48

4.4 Obtenção de fragmentos Fab no espaço periplasmático. .51

4.5 Aprimoramento das estratégias cromatográficas. . .52

4.6 Caracterização dos fragmentos Fab anti-digoxina .67

4.6.1 Determinação do ponto isoelétrico dos fragmentos Fab anti-digoxina .67

4.6.2 Caracterização da afinidade e especificidade do fragmento Fab anti-digoxina .. .68

4.6.3 Determinação dos parâmetros cinéticos de ligação .76

5 DISCUSSÃO. . .80

6 CONCLUSÕES E PERSPECTIVAS .86 REFERÊNCIAS* .88 


\section{INTRODUÇÃO}

\subsection{Insuficiência cardíaca}

Define-se insuficiência cardíaca como síndrome clínica onde ocorre a modificação funcional ou estrutural do coração que acarreta na incapacidade cardíaca de realizar a ejeção e/ou acomodação do sangue em valores pressóricos fisiológicos. Estima-se que 23 milhões de pessoas são portadoras de insuficiência cardíaca, sendo que 2 milhões de novos casos são diagnosticados no mundo anualmente (BARROS, 2008). A falta de estudos epidemiológicos a respeito da incidência da insuficiência cardíaca no Brasil dificulta o levantamento do número de pacientes que sofrem com esta patologia. De acordo com dados de outros países, estima-se que a incidência desta patologia no Brasil possa ser de até 6,4 milhões de pessoas (GUIMARÃES et al., 2002).

No ano de 2007 o Sistema Único de Saúde (SUS) registrou 111.309.325 internações. As doenças cardiovasculares, com 1.156.136 internações, foram a terceira causa das hospitalizações, sendo a insuficiência cardíaca crônica o tipo mais frequente (BOCCHI et al., 2009).

\subsection{Glicosídeos cardíacos}

Digitálicos são glicosídeos cardíacos prescritos para o tratamento de doenças cardíacas, sendo a digoxina o mais usado. Os digitálicos são formados por uma porção açúcar (glicona) e uma porção não açúcar (aglicona) composta por um esteroide e uma lactona (Figura 1). A solubilidade em água e as propriedades farmacocinéticas dos digitálicos são influenciadas pela porção glicona da molécula, enquanto a porção aglicona é responsável pela atividade farmacológica (HUNTER et al., 1982; SMITH et al., 1984). Os digitálicos diferem entre si no tamanho da cadeia de açúcar ou no número de grupos hidroxila na porção não açúcar da molécula. A digoxina, por exemplo, possui um grupo hidroxila a mais que a digitoxina e essa pequena alteração é responsável por características farmacocinéticas diferentes (KATZ et al., 2010). 
Figura 1 - Estrutura química da digoxina $\left(\mathrm{C}_{41} \mathrm{H}_{64} \mathrm{O}_{14}\right)$.

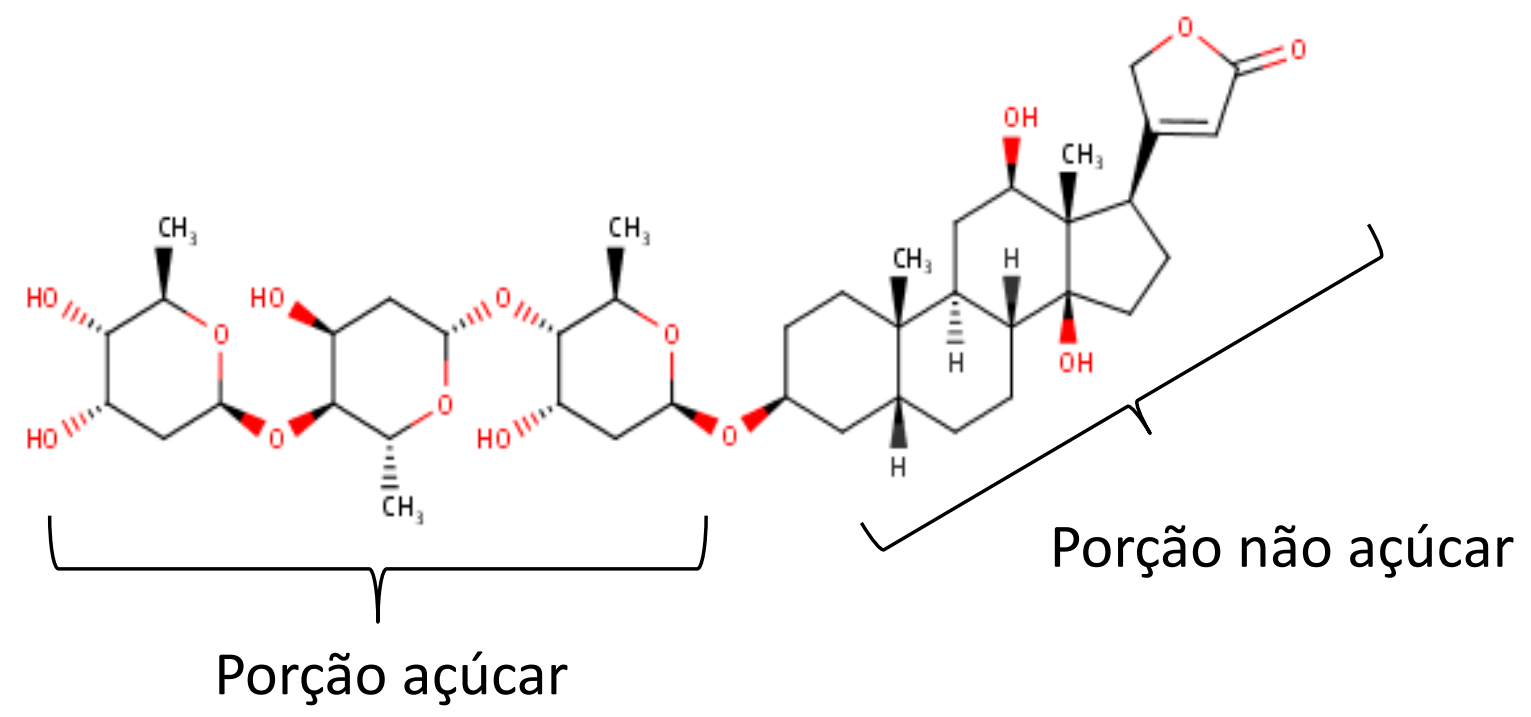

Fonte: adaptado de http://www.drugbank.ca/drugs/DB00390

O uso terapêutico dos digitálicos em humanos iniciou com uma publicação de Willian Withering em 1785 (EICHHORN; GHEORGHIADE, 2002). Os digitálicos foram inicialmente utilizados no tratamento de estados edematosos e insuficiência cardíaca crônica. De acordo com Withering os digitálicos diminuíam a frequência cardíaca, em particular dos pacientes com pulsos irregulares, e aumentava a diurese (EICHHORN; GHEORGHIADE, 2002). A partir de 1927 muitos estudos em animais e em humanos demonstraram as propriedades inotrópicas positivas dos digitálicos no miocárdio (EICHHORN; GHEORGHIADE, 2002). Este efeito inotrópico positivo está relacionado com a capacidade dos digitálicos de inibir a atividade da enzima $\mathrm{Na}^{+} \mathrm{K}^{+}$ATPase (GHEORGHIADE; PITT, 1997), conhecida como bomba de sódiopotássio, através da ligação da digoxina à subunidade $\alpha$ desta enzima. A inibição da enzima $\mathrm{Na}^{+} \mathrm{K}^{+} \mathrm{ATPase}$ causa um aumento na concentração de sódio intracelular, estimulando o intercâmbio da bomba de sódio-cálcio, que tem como consequência o aumento da concentração do cálcio intracelular. Este cálcio é utilizado pelas proteínas contráteis e gera um aumento na força de contração do miocárdio (EICHHORN; GHEORGHIADE, 2002) (Figura 2). 
Figura 2 - Esquema da inibição da bomba de sódio/potássio pelos glicosídeos cardíacos.

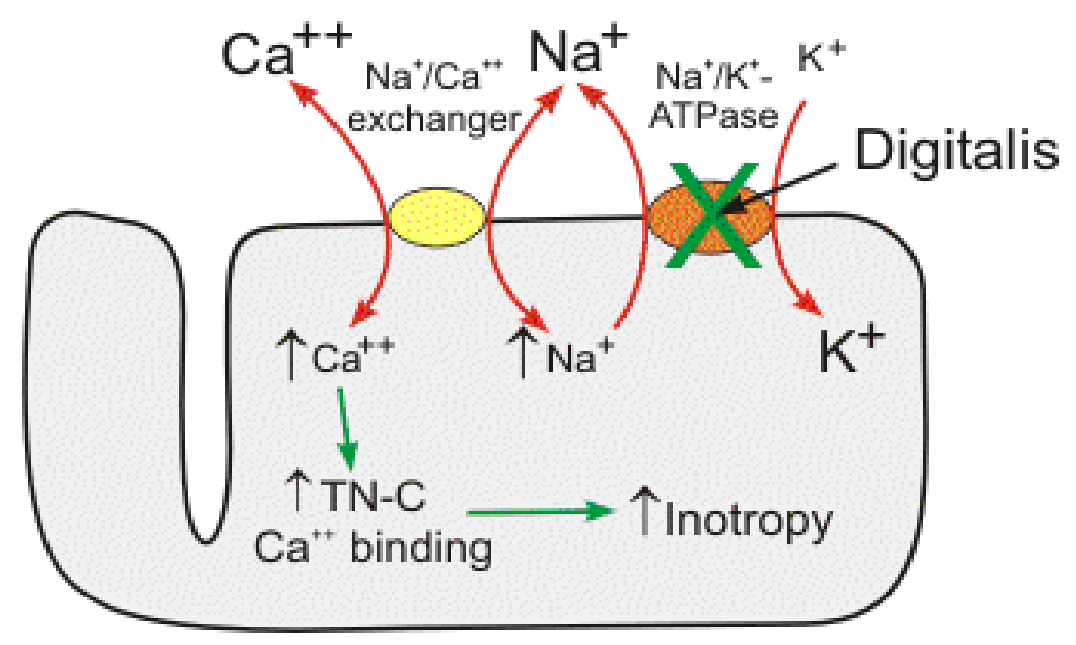

A ligação dos digitálicos cardíacos à subunidade $\alpha$ da bomba de sódio-potássio eleva o nível intracelular de sódio, o que estimula o intercâmbio pela bomba de sódio-cálcio, aumentando a concentração do cálcio intracelular utilizado pelas proteínas contráteis. Isto aumenta a força de contração do miocárdio.

Fonte: http://www.cvpharmacology.com/cardiostimulatory/digitalis

Em 1998 o FDA (Food and Drug Administration) aprovou o uso da digoxina para o tratamento da insuficiência cardíaca e fibrilação atrial, com base nos testes clínicos realizados pela PROVED (Prospective Randomized Study of Ventricular Function and Efficacy of Digoxin), RADIANCE (Randomized Assessment of Digoxin on Inhibitors of the Angiotensin Converting Enzyme) e DIG (Digoxin Investigation Group) (GHEORGHIADE et al., 2006). Apesar da aprovação da digoxina, o seu uso em pacientes com insuficiência cardíaca vem diminuindo (GOLDBERGER; ALEXANDER, 2014). Um dos fatores é o desenvolvimento de novos medicamentos como B-bloqueadores, inibidores da enzima conversora da angiotensina (ECA), bloqueador de receptor da angiotensina (ARBs, angiotensin receptor blockers) e bloqueadores de aldosterona. Os estudos clínicos mostraram que a digoxina, em combinação com as drogas recentes, melhorou o estado clínico e reduziu a hospitalização do paciente, confirmando a sua importância no tratamento da insuficiência cardíaca crônica (GHEORGHIADE et al., 2006). A análise conjunta dos testes clínicos RADIANCE e PROVED sugeriu que a associação tripla formada pela digoxina, um inibidor ECA e um diurético diminuiu o risco de agravamento do quadro clínico da insuficiência cardíaca $(<5 \%)$ e também se verificou uma significante redução do custo relacionado com a hospitalização dos pacientes (GHEORGHIADE et al., 2006). No ensaio clínico DIG observou-se que os pacientes com insuficiência 
cardíaca crônica acima de 65 anos e tratados previamente com inibidores de ECA e diuréticos, ao receber digoxina apresentaram redução de $34 \%$ na readmissão hospitalar no intervalo de 30 dias, independente da causa, em comparação aos pacientes que receberam placebo (BOURGE et al., 2013).

A digoxina, por ser uma droga de baixo custo, tem sua importância aumentada em países em desenvolvimento onde os pacientes têm acesso limitado aos medicamentos de última geração. Quando a digoxina é administrada em doses apropriadas é bem tolerada e segura (GHEORGHIADE et al., 2006). No Brasil o uso da digoxina é descrito na Relação Nacional de Medicamentos Essenciais (RENAME) para o tratamento da insuficiência cardíaca (BRASIL, 2015).

\subsection{Intoxicação digitálica}

A janela terapêutica dos digitálicos é estreita, sendo sua toxicidade a principal reação adversa verificada pelos clínicos (ANDRES, 2000). No ensaio clínico DIG a concentração sérica da digoxina foi considerada terapêutica na faixa entre 0,5 e $2 \mathrm{ng} / \mathrm{mL}$. Entretanto, os guias mais recentes recomendam que a concentração sérica da digoxina deva ser entre 0,5 e $0,9 \mathrm{ng} / \mathrm{mL}$, após análise posterior do DIG e dos resultados de outros ensaios clínicos (AMBROSY et al., 2014). No ensaio clínico PROMISE - PROSPECTIVE RANDOMIZED MILRINONE SURVIVAL EVALUATION foi verificado um aumento de $38 \%$ da mortalidade em pacientes com concentração sérica de digoxina superior a 1,1 ng/mL (EICHHORN; GHEORGHIADE, 2002). Foi observada em outro estudo uma redução da mortalidade e da hospitalização em pacientes acima de 65 anos quando a concentração sérica da digoxina era baixa (0,5 a 0,9 ng/mL) (AHMED, 2007). A concentração sérica da digoxina não é determinada somente pela quantidade administrada, mas também em função de interações com outros medicamentos e das condições renais do paciente, visto que a eliminação predominante da digoxina é efetuada por esta via (ANTMAN; SMITH, 1985; EICHHORN; GHEORGHIADE, 2002). A maior incidência na intoxicação causada pela digoxina foi verificada em pacientes com a função renal debilitada (SMITH; BUTLER; HABER, 1970).

A incidência de toxicidade da digoxina observada tem sido menor que $1 \% \mathrm{e}$ no máximo $5 \%$ e em mais de $95 \%$ dos casos ocorreram em pacientes com concentração sérica de digoxina maior que $2 \mathrm{ng} / \mathrm{mL}$ (AMBROSY et al., 2014). Em 
2010 foram registrados nos Estados Unidos 2.458 casos de intoxicação por glicosídeos cardiogênicos, sendo 166 casos graves e 32 óbitos (GALVÃO et al., 2013). Espera-se um aumento na exposição aos digitálicos no Brasil, uma vez que os casos de insuficiência cardíaca com a indicação de tratamento farmacológico são crescentes (GALVÃO et al., 2013).

A intoxicação por digitálicos pode ser fatal, principalmente em pacientes com disfunção cardíaca grave, pela ingestão acidental de alta dose de digitálicos ou pela intenção de suicídio. Os efeitos causados pela intoxicação são hipercalemia, bloqueio atrioventricular e taquiarritmia ventricular maligna (ANTMAN et al, 1990). O tratamento de primeira linha recomendado atualmente nas intoxicações graves por digitálicos é a utilização de anticorpos policlonais anti-digoxina na forma de fragmentos Fab (fragment antigen binding). Infelizmente este tratamento é indicado somente quando outras opções de tratamento falham, devido ao seu alto custo (FLANAGAN; JONES, 2004).

Para o tratamento da intoxicação por digoxina, há tempos buscou-se desenvolver um antídoto, na forma de anticorpos neutralizantes. Por possuir apenas 780,92 Daltons, a digoxina não é antigênica, sendo necessária a ligação covalente a um carreador proteico para a produção de anticorpos específicos anti-digoxina. Em 1967, a digoxina foi conjugada com albumina sérica bovina, para a obtenção de anticorpos específicos em coelhos (BUTLER; CHEN, 1967). Para a produção comercial dos anticorpos anti-digoxina, os autores imunizaram ovelhas, obtendo anticorpos policlonais com alta afinidade e especificidade, que foram purificados e clivados pela enzima papaína, para gerar os fragmentos Fab (PROTHERICS, 2001).

$O$ uso de fragmentos Fab anti-digoxina como tratamento da intoxicação causada pela digoxina foi reportado inicialmente em 1976 (ANTMAN et al., 1990). Estes fragmentos $\mathrm{Fab}$ quando administrados por via intravenosa em pacientes com intoxicação digitálica, ligam-se tanto aos glicosídeos circulantes livres como também removem os glicosídeos ligados à bomba de sódio e potássio. Isso ocorre porque a afinidade dos fragmentos Fab anti-digoxina à digoxina é superior à afinidade de ligação entre o receptor endógeno (subunidade $\alpha$ da bomba de sódio e potássio) e a digoxina, formando complexos estáveis antígeno-Fab. Tanto estes complexos quanto os fragmentos Fab livres são excretados de forma relativamente rápida pela urina, resultando em uma rápida reversão da toxicidade, sendo portanto um produto adequado para o tratamento da intoxicação ocasionada pelo excesso de digitálicos. 
Não obstante, o processo de excreção é menos eficiente em pacientes com função renal comprometida (CHAN; BUCKLEY, 2014; FLANAGAN; JONES, 2004).

\subsection{Cenário econômico para o fragmento Fab anti-digoxina}

Nos EUA até o ano de 2011 existiam dois produtores comerciais do fragmento Fab policlonal anti-digoxina gerado em ovelha, o Digibind ${ }^{\circledR}$ (GlaxoSmithKline, Parma, Itália) e $\circ$ DigiFab $^{\circledR}$ (BTG, Londres, Inglaterra) com preços similares (Digibind ${ }^{\circledR}$ US $\$ 797,00$ por frasco contendo $38 \mathrm{mg}$ e DigiFab ${ }^{\circledR}$ US $\$ 786,00$ por frasco contendo $40 \mathrm{mg}$ ). Entretanto, a GlaxoSmithKline descontinuou a venda do seu produto em 2011. A BTG com a obtenção do monopólio da comercialização do fragmento Fab policlonal anti-digoxina, neste mesmo ano, elevou o preço do DigiFab ${ }^{\circledR}$ em $15 \%$ (US\$ 903 por frasco contendo $40 \mathrm{mg}$ ). Diante deste cenário a falta de concorrência permitiu que a BTG continuasse a elevar o preço do seu produto. Em março de 2014 o produto atingiu o valor de US\$2.370,00 o frasco com $40 \mathrm{mg}$ (JOHNSON et al, 2015). Para a reversão de casos agudos de intoxicação o fabricante recomenda a utilização de até 20 frascos do antídoto, correspondendo a US\$47.400,00. A utilização de um número maior de frascos pode ser necessária, dependendo da quantidade de digoxina consumida (BTG, 2012).

Para a utilização dos fragmentos Fab anti-digoxina no Brasil é necessária a importação, que é autorizada pela Agência Nacional de Vigilância Sanitária conforme resolução RDC $n^{\circ} 28$, de 09 de maio de 2008 atualizada pela RDC $n . .9$, de 28 de fevereiro de 2014, destinado exclusivamente para uso hospitalar ou sob prescrição médica, sendo sua importação vinculada a uma entidade hospitalar ou entidade civil representativa. A importação para fins comerciais é proibida (BRASIL, 2008; BRASIL, 2014).

O futuro no uso dos fragmentos Fab anti-digoxina não está limitado a casos de intoxicação por digitálicos, uma vez que estes fragmentos têm capacidade de neutralizar moléculas endógenas denominadas esteroides cardiotônicos, ou digitalis like através da reação cruzada. Estas moléculas endógenas possuem efeitos semelhantes aos glicosídeos cardíacos, inibindo a bomba de sódio-potássio e aumentando a pressão arterial. Verificou-se um aumento dos níveis circulantes destas moléculas em grávidas com hipertensão gestacional e pré-eclâmpsia. Apesar da pré-eclâmpsia ocorrer em apenas 3 a $5 \%$ do total de grávidas, trata-se de uma 
complicação grave, podendo causar mortalidade materna e fetal (BAGROV et al., 2009; ZAZERSKAYA et al., 2013). Em 2012 a empresa Glenveigh Medical, que possui a licença intelectual do fragmento Fab anti-digoxina - DigiFab ${ }^{\circledR}$, recebeu do FDA a designação de "Fast track" o que possibilita a redução no tempo para a aprovação do uso deste medicamento para o tratamento da pré-eclâmpsia (REUTERS, 2012).

\subsection{Anticorpos}

Anticorpos ou imunoglobulinas são glicoproteínas estruturalmente semelhantes produzidas pelos linfócitos $B$, que possuem como principais funções: ligar-se especificamente a antígenos e recrutar células e/ou moléculas capazes de eliminar o patógeno ao qual foi apresentado. O anticorpo possui sequência única, permitindo a ligação a um epítopo específico presente no antígeno. Estruturalmente eles possuem as mesmas características básicas, mas apresentam elevada variabilidade na região de ligação aos antígenos.

Os anticorpos são representados em classes determinadas pelo tipo de cadeia pesada presente, podendo ser divididos em $\lg A, \lg \mathrm{D}, \lg \mathrm{E}, \lg \mathrm{G}$ e $\lg \mathrm{M}$. A classe mais frequente em humanos é a lgG, subdividido em várias subclasses (lgG1, IgG2a, IgG2b, IgG3 e IgG4). Existem 2 classes de cadeias leves: lambda $(\lambda)$ e kappa (к). Uma molécula de anticorpo apresenta 2 cadeias leves idênticas $\mathrm{k}$ ou $\lambda$, não sendo possível a coexistência dos 2 tipos a uma mesma molécula de anticorpo. Em seres humanos, 60\% dos anticorpos apresentam cadeia leve do tipo $\mathrm{k}$ e cerca de $40 \%$, cadeias leves $\lambda$. Em camundongos os anticorpos contendo cadeia $\mathrm{k}$ são cerca de 10 vezes mais abundantes do que os portadores da cadeia leve $\lambda$ (ABBAS, 2011).

O peso molecular do anticorpo da classe lgG é de aproximadamente $150 \mathrm{kDa}$, com variações conforme o isotipo. São formados por cadeias polipeptídicas leves (LC, light chain) idênticas com peso aproximado de 25 kDa e duas cadeias pesadas (HC, heavy chain) idênticas de 50 kDa. Ambas possuem uma região aminoterminal variável ( $\mathrm{V}_{\mathrm{H}}$, Variable Heavy e $\mathrm{V}_{\mathrm{L}}$, Variable Light) de reconhecimento e ligação ao antígeno e regiões carboxiterminais constantes $\left(\mathrm{C}_{\mathrm{H}}\right.$, Constant Heavy e $\mathrm{C}_{\mathrm{L}}$, Constant Light) (Figura 3). 
Figura 3 - Estrutura da imunoglobulina da classe IgG.

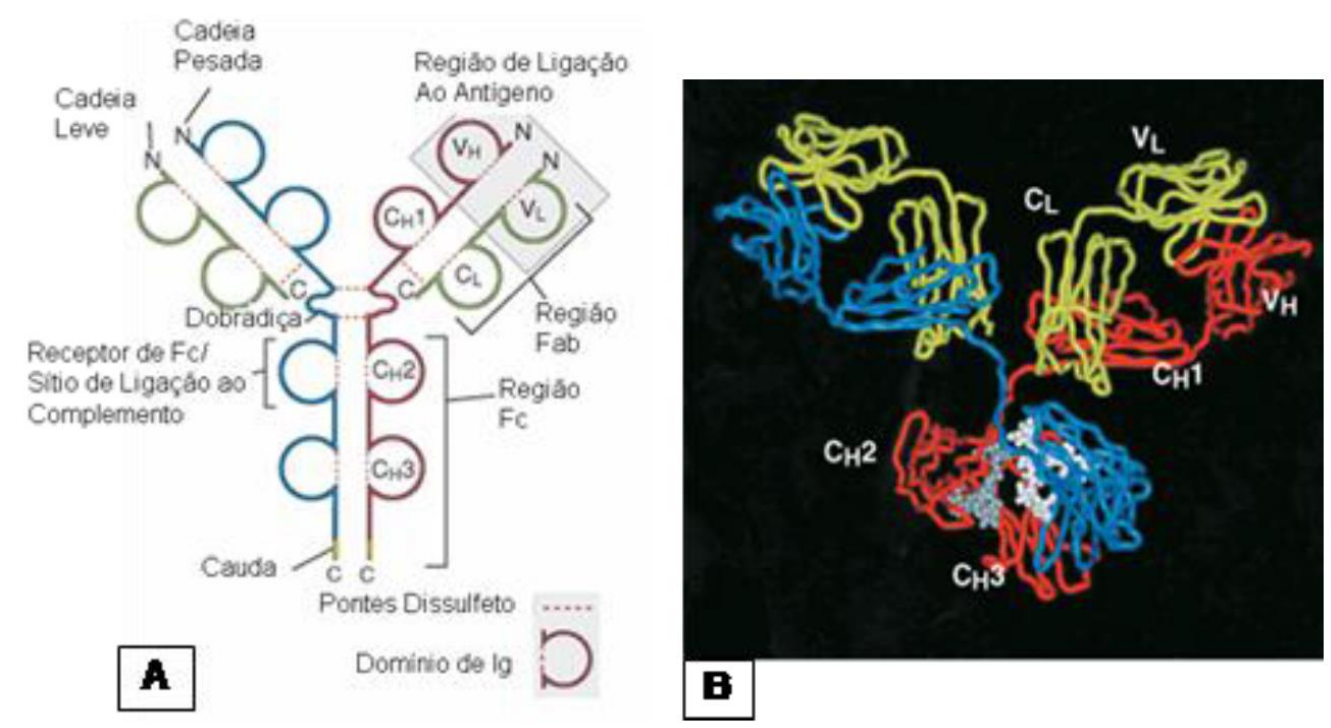

A) diagrama esquemático de uma IgG secretada; B) cristalografia de raios $\mathrm{X}$, cadeias pesadas em azul e vermelho, cadeias leves em verde; os carboidratos em cinza.

FONTE: ABBAS et al., 2011.

As 2 cadeias pesadas de cada molécula de anticorpo são ligadas covalentemente por pontes de dissulfeto. As cadeias leves e pesadas são também unidas por pontes de dissulfeto formadas entre resíduos de cisteína na região carboxiterminal da cadeia leve e o domínio $\mathrm{C}_{\mathrm{H}} 1$ da cadeia pesada. Ambas as cadeias possuem unidades de estrutura semelhante, com cerca de 110 aminoácidos, que se dobram de maneira independente em um formato globular, nomeado de domínio da imunoglobulina. As cadeias leves possuem 2 domínios ( $V_{L}$ e $\left.\mathrm{C}_{\mathrm{L}}\right)$ enquanto as cadeias pesadas contêm $4\left(\mathrm{~V}_{\mathrm{H}}, \mathrm{C}_{\mathrm{H}} 1, \mathrm{C}_{\mathrm{H}} 2\right.$ e $\left.\mathrm{C}_{\mathrm{H}} 3\right)$ para as imunoglobulinas G (ABBAS, 2011).

As regiões variáveis pesadas e leves possuem 3 regiões hipervariáveis, também conhecidas como regiões determinantes de complementariedade (CDRs, complementarity determining regions), nomeadas a partir da porção aminoterminal de CDR1, CDR2 e CDR3, sendo o CDR3 a mais variável. Entre estas regiões estão presentes sequências mais conservadas chamadas de arcabouço ou framework regions. A ligação do anticorpo ao alvo ocorre pelas regiões de CDR das cadeias leve e pesada. As cadeias pesadas também determinam as funções efetoras dos anticorpos, pela interação da região carboxiterminal com receptores presentes na superfície de alguns tipos celulares. 
Em 1972, Rodney Porter tratou imunoglobulinas $G$ de coelhos com enzimas proteolíticas, resultando na clivagem da mesma em fragmentos com estrutura e funções diferentes. Quando utilizada a enzima papaína, originaram-se três fragmentos. $\mathrm{O}$ fragmento formado pelos domínios $\mathrm{C}_{\mathrm{H}} 2$ e $\mathrm{C}_{\mathrm{H}} 3$ da molécula de $\mathrm{lg} \mathrm{G}$, ligados entre si por pontes dissulfeto, era capaz de se auto-associar e cristalizar, por isso denominado Fc (Fragment cristalizable). Dois fragmentos idênticos formados pela cadeia leve completa $\left(V_{\mathrm{L}}\right.$ e $\left.\mathrm{C}_{\mathrm{L}}\right)$ associada a um fragmento $\mathrm{V}_{\mathrm{H}}-\mathrm{C}_{\mathrm{H}} 1$ da cadeia pesada, foram chamados de Fab (Fragment antigen binding) e apresentaram como características a manutenção da capacidade de ligação ao antígeno por conterem os domínios $V_{L}$ e $V_{H}$ pareados (Figura $4 A$ ). Porter realizou o mesmo experimento, com a substituição da papaína pela pepsina, resultando em apenas um fragmento denominado $F\left(a b^{\prime}\right)_{2}$, o qual continha a região de ligação ao antígeno e pontes dissulfeto intercaladas e intactas, sendo o restante da molécula degradada (Figura 4B) (ABBAS, 2011). Entre outras características, os fragmentos Fab são menos imunogênicos do que a IgG inteira, possuem melhor difusão no espaço intersticial e são facilmente eliminados por filtração glomerular (FLANAGAN; JONES, 2004).

Figura 4 - Resultados da digestão enzimática de anticorpos.
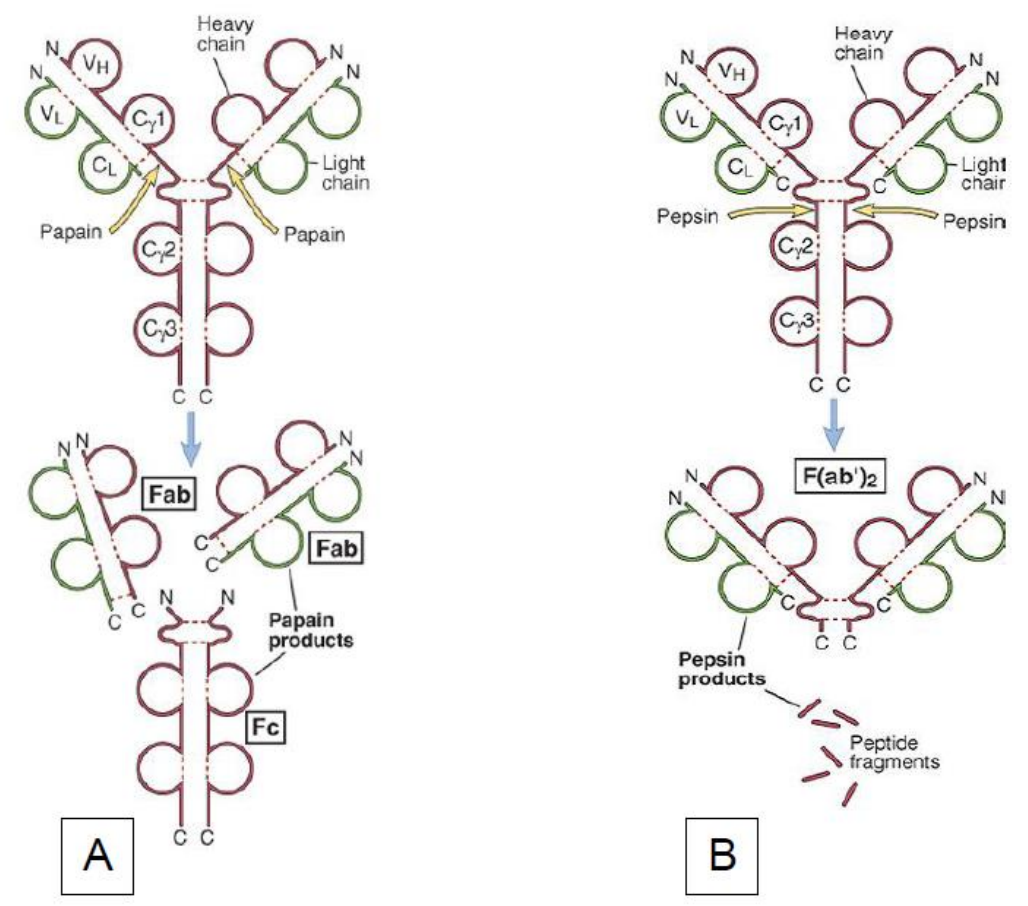

A) Fragmentos de uma molécula de IgG submetida ao tratamento com papaína, resultando em dois fragmentos $\mathrm{Fab}\left(\mathrm{V}_{\mathrm{L}}, \mathrm{C}_{\mathrm{L}}, \mathrm{V}_{\mathrm{H}}\right.$ e $\left.\mathrm{C}_{\mathrm{H}} 1\right)$ e um fragmento $\mathrm{Fc}_{\mathrm{C}}\left(\mathrm{C}_{\mathrm{H}} 2 \mathrm{E} \mathrm{C}_{\mathrm{H}} 3\right)$. B) Tratamento com pepsina resultando em um fragmento $F(a b)_{2}$.

FONTE: ABBAS et al., 2011. 
Em 1975 Milstein e Köhler desenvolveram a metodologia para obtenção de anticorpos monoclonais (AcMos), sendo laureados pelo prêmio Nobel de Fisiologia e Medicina em 1984. Esta técnica se baseia na imunização de animais com o antígeno de interesse seguido do isolamento das células $B$ do baço ou linfonodos do animal $e$ a fusão destas células às células de mielomas, originando híbridos produtores de AcMo (KOHLER; MILSTEIN, 1975).

O primeiro AcMo aprovado pelo FDA para uso terapêutico em humanos foi o anticorpo murino Muromab-CD3 (Orthoclone-OKT3, Johnson \& Johnson) com aplicação na prevenção e controle da rejeição aguda a transplantes. O sucesso obtido pelo OKT3 estimulou o desenvolvimento de outros AcMos para tratamento ou diagnóstico de doenças humanas, obtidos pelas técnicas de humanização dos AcMos murinos através da engenharia de anticorpos (MORO; RODRIGUES, 2001). Uma das ferramentas disponíveis para a seleção dos AcMos recombinantes e fragmentos de anticorpos é a técnica de phage display.

\subsection{Phage display}

A tecnologia de phage display foi descrita por George Smith em 1985 como um método de apresentação de polipeptídios exógenos em fusão com uma proteína da superfície do bacteriófago (fago), correlacionando o genótipo e o fenótipo dos fagos (SMITH, 1985). Neste trabalho a construção da biblioteca de polipeptídeos permitiu a apresentação dos mesmos pelos fagos e a seleção de ligantes específicos para um determinado anticorpo (SMITH, 1985). Desde então a tecnologia de phage display tem sido bastante utilizada em estudos que envolvem peptídeos e proteínas tanto na área acadêmica como em diagnóstico e na terapêutica. A técnica pode ser utilizada nos estudos de interação proteína-ligante, análise dos sítios de ligação do receptor e para aumentar ou alterar a afinidade das proteínas pelos seus ligantes. Além disso, esta tecnologia pode ser aplicada na obtenção de AcMos e para aumentar a afinidade entre o anticorpo e seu antígeno (BAZAN, 2012). Em relação à obtenção de AcMos, inicia-se pela construção de bibliotecas de genes de fragmentos de anticorpos no formato Fab ou scFv, provenientes de diversas fontes, animal ou humana (após imunização ou não), hibridoma, entre outras. Antes de selecionar os clones que expressam um anticorpo específico, a biblioteca pode ser enriquecida com clones que apresentam afinidade 
ao antígeno através de algumas rodadas de panning. Este processo é composto das seguintes etapas: amplificação da biblioteca, ligação dos fragmentos expressos pelo fago ao antígeno imobilizado numa superfície, eluição dos fagos que se ligaram ao antígeno e amplificação da nova biblioteca para uma nova rodada de enriquecimento (WINTER et al., 1994).

\subsection{Purificação}

Para o uso clinico de biomoléculas é imprescindível à obtenção de alto grau de pureza, fazendo-se necessário a utilização de variadas técnicas de purificação para alcançar o nível exigido.

A purificação de biomoléculas pode ser realizada por diversas técnicas, tais como precipitação, centrifugação, eletroforese, cromatografia líquida dentre outros. O fator determinante para o uso de uma técnica ou outra, ou até mesmo o conjunto de técnicas, recai no tipo de aplicação da molécula de interesse, por exemplo, proteínas com fins terapêuticos requerem elevado grau de pureza, assim como algumas finalidades acadêmicas como estudos de cristalização.

As características físico-químicas das moléculas biológicas, como afinidade biológica, carga elétrica, tamanho molecular, hidrofobicidade podem ser exploradas nos processos cromatográficos. Atualmente está disponível comercialmente uma vasta gama de resinas cromatográficas com diferentes metodologias para a separação dos contaminantes. Os métodos cromatográficos com maior utilização são: cromatografia de afinidade, troca iônica, exclusão molecular e interação hidrofóbica (Tabela 1) (SILVA, 2004).

Tabela 1 - Técnicas Cromatográficas e seus princípios.

\begin{tabular}{ll}
\hline Técnica & Princípio \\
\hline Afinidade & Ligação específica \\
Troca iônica & Carga elétrica \\
Exclusão molecular & Tamanho \\
Interação hidrofóbica & Hidrofobicidade \\
Fase reversa & Hidrofobicidade \\
\hline
\end{tabular}

\subsubsection{Métodos cromatográficos}

A cromatografia de afinidade baseia-se na interação específica e reversível entre uma proteína a ser purificada e um ligante, acoplado a uma matriz (ROY; 
GUPTA, 2003). Esta metodologia permite a obtenção de proteínas com elevado grau de pureza em apenas uma etapa cromatográfica (HERMANS; ADAMS; DETMERS, 2014).

A cromatografia de troca iônica permite a separação de proteínas explorando as diferenças entre as cargas superficiais líquidas das proteínas. A carga superficial da proteína, que pode variar em função do $\mathrm{pH}$ da solução onde se encontra, interage com a carga oposta presente no meio cromatográfico (KARLSSON; RYDEN; BREWER, 1998). Quando uma proteína está presente em um ambiente com pH acima do seu ponto isoelétrico ( $\mathrm{pl}$ ) ela estará carregada negativamente permitindo a sua interação com resinas de troca aniônica, enquanto que, quando presente em um ambiente com $\mathrm{pH}$ inferior ao seu $\mathrm{pl}$, estará carregada positivamente, possibilitando 0 uso de resinas com troca catiônica para a separação.

O processo cromatográfico de exclusão molecular ou também chamado de gel filtração explora o tamanho molecular para proceder à separação. Para tanto, a substância a ser purificada é aplicada à matriz cromatográfica, a qual é composta por grânulos ("beads") com poros de tamanhos diferentes; as substâncias que possuem maior tamanho molecular são eluídas antes da coluna cromatográfica por não penetrarem nos poros, e as substâncias de tamanhos menores penetram nos poros presentes nos grânulos retardando a sua eluição.

As características de hidrofobicidade das moléculas são exploradas pela cromatografia de interação hidrofóbica, a qual se baseia na interação entre os ligantes hidrofóbicos (presentes no meio cromatográfico) e os resíduos hidrofóbicos na superfície das proteínas (ERIKSSON, 1998). Em ambientes com elevadas concentrações salinas as proteínas expõem seus grupamentos hidrofóbicos, conferindo maior adsorção com o meio cromatográfico, para a reversão da interação obtida nesta estratégia, é realizada a redução da concentração de sal (força iônica), podendo chegar à total ausência de sal (passagem de água) (GHOSE et al., 2009). Usualmente, esta metodologia é realizada como um passo de purificação posterior aos métodos que resultam na eluição em grandes concentrações de sais, como exemplo, precipitação por sulfato de amônio ou eluatos contendo altas concentrações de sais oriundos de cromatografias de troca iônica. Uma variante desta metodologia que também tem por principio a interação hidrofóbica é a cromatografia de fase reversa que possui um meio cromatográfico com alta hidrofobicidade promovendo uma forte interação entre a resina cromatografia e a 
molécula, sendo necessário o uso de solventes orgânicos para a reversão desta interação. Os solventes orgânicos representam condições drásticas que podem alterar a conformação das proteínas (WHEELWRIGHT, 1991).

\subsubsection{Purificação de anticorpos monoclonais}

Com o isolamento e a caracterização de proteínas bacterianas capazes de interagir com as imunoglobulinas, foi possível a utilização destas proteínas para o isolamento de anticorpos. A proteína A oriunda dos Staphylococcus aureus e a proteína $\mathrm{G}$ obtida dos Streptococcus grupos $C$ e $G$ são as de maior aplicação para o isolamento das imunoglobulinas da classe $G$, estas duas proteínas ligam-se predominantemente na porção Fc das imunoglobulinas (NILSON et al., 1993).

O processo de purificação de AcMos terapêuticos é tradicionalmente realizado pelo uso de colunas cromatográficas intercalado com o uso de etapas de concentração e troca de tampão (diafiltração) (CHON; ZARBIS-PAPASTOITSIS, 2011). Tipicamente, a purificação de AcMos é composta pela etapa de clarificação do sobrenadante da cultura celular, seguido pelas etapas cromatográficas de:

- Afinidade em resina de proteína A ou G - captura dos anticorpos e redução do volume;

- Catiônica - remoção de resíduos de proteína $A$, proteínas da célula hospedeira e DNA;

- Aniônica - remoção de vírus, proteínas da célula hospedeira, endotoxinas e DNA;

Também são realizadas etapas de inativação viral que podem ser efetuadas com a exposição dos AcMos a condições de pH ácido, seguida de neutralização ( $\mathrm{pH}$ shifting), geralmente realizada durante a cromatografia por afinidade em proteína A, visto o uso de tampões com $\mathrm{pH}$ ácido para a remoção do material adsorvido na coluna cromatográfica. Outros métodos utilizados para a inativação viral incluem tratamentos com detergentes/solventes ou filtração (MARQUES; ROUSH; GÖKLEN, 2009).

\subsubsection{Purificação de fragmentos Fab de anticorpos}

As resinas de afinidade proteína $A$ e $G$, além de serem vastamente utilizadas para a purificação de anticorpos, também podem ser utilizadas para a purificação de 
fragmentos Fab, apesar da diminuída atividade de interação que possuem com os fragmentos Fab. A proteína $A$ é restrita à porção $V_{H}$ Ill, e a especificidade da proteína $G$ é dirigida ao $C_{H} 1$ da imunoglobulina. Outra proteína obtida de bactérias que possui interação com os fragmentos de anticorpos é a proteína $L$, obtida da espécie bacteriana Peptostreptoccus magnus, com especificidade para a região variável da cadeia leve das imunoglobulinas, sem interferência no sitio de ligação ao antígeno (NILSON, 1993; RODRIGO; GRUVEGARD; ALSTINE, 2015).

$\mathrm{Na}$ purificação de fragmentos Fab de anticorpos existem alguns aspectos que devem ser levados em conta, como a forma de obtenção do fragmento (digestão dos anticorpos inteiros por papaína ou obtidos pelo de uso de técnicas de engenharia genética), a espécie de origem (humano, murino, etc.) e a existência ou não de caudas ou marcadores que facilitariam o isolamento com a utilização de resinas de afinidade, como por exemplo, a purificação de proteínas contendo cauda de histidina com o uso de resinas de afinidade por metal.

A purificação dos fragmentos de anticorpos também pode ser realizada com a utilização de resinas de troca catiônica, as quais em situações bem estabelecidas, permitem a obtenção de níveis dinâmicos de ligação dos fragmentos de anticorpos superiores a $100 \mathrm{~g} / \mathrm{L}$ (RODRIGO; GRUVEGARD; ALSTINE, 2015).

\subsection{Obtenção dos fragmentos Fab monoclonal anti-digoxina}

A tecnologia de phage display foi utilizada em um trabalho anterior do nosso laboratório para a seleção de clones do fragmento Fab anti-digoxina, expressos em Escherichia coli (E. coli). Para a obtenção desses clones, partiu-se da extração do RNA total do hibridoma anti-digoxina. Os genes da cadeia leve e pesada dos fragmentos Fab foram amplificados com oligonucleotídeos específicos após síntese de cDNAs e clonados sequencialmente em vetor fagomídeo para a construção da biblioteca combinatória anti-digoxina. Em seguida, a biblioteca foi enriquecida por rodadas de panning através da ligação do fragmento Fab expresso pelo fago à digoxina conjugada com BSA (Dig-BSA). Após o enriquecimento, 10 clones foram selecionados aleatoriamente e a presença dos insertos da cadeia leve e pesada nos clones foi avaliada. Dos clones analisados, 6 apresentaram os 2 insertos e tiveram os genes das 2 cadeias sequenciados. Os clones sequenciados apresentaram sequências de aminoácidos idênticas para a cadeia pesada. Quatro clones 
apresentaram diferenças na sequência de aminoácidos na região do framework 1 da cadeia leve. O clone 9 apresentou um resíduo de aminoácido diferente no CDR2 da cadeia leve em relação aos outros clones. $O$ fragmento Fab solúvel dos 4 clones foi expresso em $E$. coli e o anticorpo presente no lisado bacteriano foi quantificado e avaliado em relação à afinidade ao antígeno (MURATA, 2012; MURATA et al., 2013).

O vetor fagomídeo pComb3XTT (BARBAS et al., 2001) (Figura 5), utilizado para clonagem dos fragmentos Fab, foi obtido do Instituto Scripps (The Scripps Research Institute, EUA). Este vetor pertence à família pComb3X (Genbank AF268281) e é composto pelos genes da cadeia leve (LC) e cadeia pesada (HC) do fragmento Fab humano para a toxina tetânica "TT", por um promotor lacZ, pela origem de replicação $F 1$ Ori, resistência à ampicilina $a m p R$, cauda de seis histidinas (His6) e de 10 hemaglutininas (HA) que facilitam a detecção e purificação do fragmento Fab. As cadeias polipeptídicas são direcionadas para o espaço periplasmático pela existência de dois peptídeos sinais, ompA (outer membrane protein) para LC e (pelB) pectate lyase $B$ para HC. Possui também um códon de terminação âmbar (TAG), que com o uso de linhagens bacterianas não supressoras permite a expressão da proteína solúvel sem a proteína p3. A existência dos sítios de restrição Spel e Nhel possibilita a remoção do gene da proteína p3, através da digestão pelas respectivas enzimas de restrição e religação do vetor, permitindo a expressão da proteína solúvel com o uso de bactérias supressoras. Neste trabalho optou-se pelo uso de bactérias supressoras, com a remoção do gene da proteína p3. Como consequência da estratégia usada para a expressão dos fragmentos Fab, perdeu-se a região contendo a cauda de histidinas.

No presente trabalho os fragmentos Fab anti-digoxina dos 4 clones anteriormente selecionados foram expressos em cultivos bacterianos para estabelecer o método de purificação dos fragmentos $\mathrm{Fab}$ e proceder à sua caracterização. A presença do anticorpo foi verificada tanto no lisado bacteriano como no sobrenadante do cultivo, sendo observada maior quantidade de fragmento Fab no sobrenadante. Foram testadas várias estratégias de purificação como a utilização de resinas de afinidade, de troca catiônica e aniônica, para a obtenção de fragmentos Fab anti-digoxina purificados. 
Figura 5 - Vetor fagomídeo pComb3XTT.

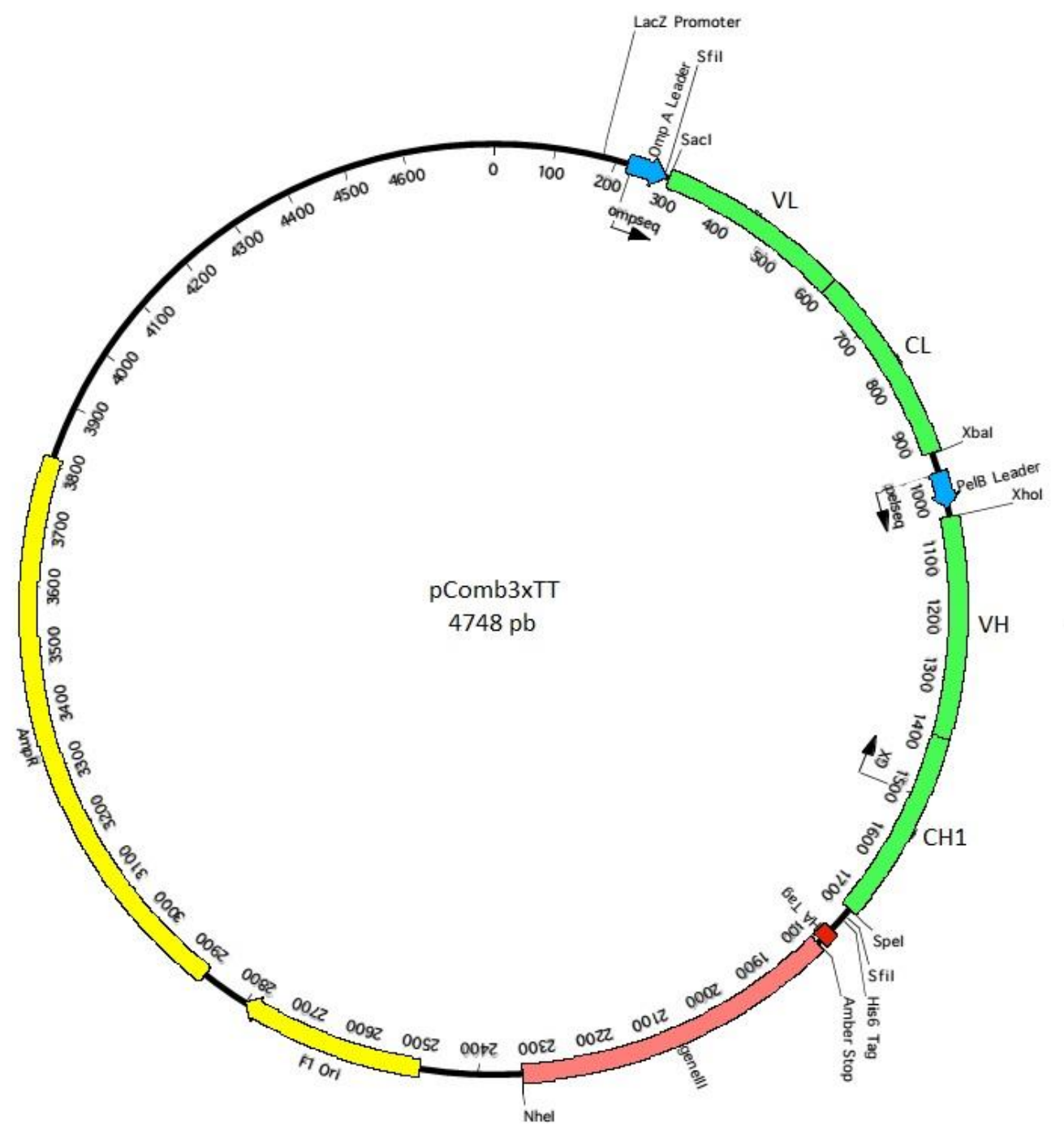

Os genes das cadeias LC e HC do fragmento humano para a toxina tetânica "TT", foram clonados nos sítios de restrição Sacl - Xbal e Xhol - Spel, respectivamente.

FONTE:http://www.scripps.edu/mb/barbas/content/pcomb_images/pcomb_image_files/pComb_Maps/ pComb3X_Maps.pdf, adaptado. 


\section{OBJETIVOS}

\subsection{Objetivo Geral}

Testar estratégias cromatográficas para a purificação dos fragmentos Fab antidigoxina visando um alto grau de pureza e caracterizar os fragmentos Fab purificados em relação à afinidade de ligação à digoxina e seus análogos, comparando com o produto comercial (DigiFab ${ }^{\circledR}$ ), para a definição do clone principal.

\subsection{Objetivos Específicos}

- Expressar o fragmento Fab anti-digoxina dos 4 clones pré-selecionados para obtenção de massa para ensaios.

- Avaliar estratégias de purificação dos fragmentos Fab anti-digoxina através de processos cromatográficos.

- Caracterizar a interação entre os fragmentos Fab anti-digoxina purificados com o antígeno e a especificidade do anticorpo à digoxina e seus análogos (digitoxina, digoxigenina e ouabaina).

- Realizar ensaios de cinética de ligação e dissociação ao conjugado Dig-BSA.

- Selecionar o clone que apresente melhor especificidade à digoxina e seus análogos. 


\section{MATERIAIS E MÉTODOS}

3.1 Linhagem bacteriana, meios de cultura, suplementos e soluções utilizadas nos cultivos bacterianos

- Ampicilina $100 \mathrm{mg} / \mathrm{mL}$ - solução estoque.

- Cloreto de magnésio $2 \mathrm{M}$ - solução estoque.

- E. coli XL1-Blue Competent Cells (Stratagene Corporation, EUA).

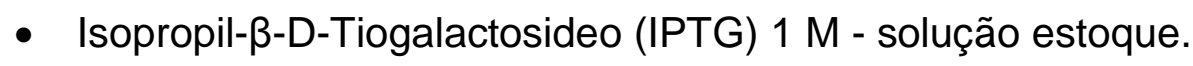

- Luria-Bertani (LB) - ágar: triptona $1 \%$; extrato de levedura $0,5 \% ; \mathrm{NaCl} 1 \%$; ágar $1,5 \%$.

- SOC: triptona 2\%; extrato de levedura 0,5\%; $\mathrm{NaCl} 0,05 \% ; \mathrm{KCl} 20 \mathrm{mM}$; $\mathrm{MgCl}_{2} 1 \mathrm{mM}$; glicose $20 \mathrm{mM}$.

- Super Broth (SB): triptona 3\%; extrato de levedura 2\%; MOPS 1\%, pH 7,0.

\subsection{Colunas e resinas cromatográficas}

- Coluna cromatográfica: C10/10 (GE Healthcare, Uppsala, Suécia).

- Coluna cromatográfica: XK 26/20 (GE Healthcare, Uppsala, Suécia).

- HiTrap ${ }^{\mathrm{TM}}$ Protein L $1 \mathrm{~mL}$ (GE Healthcare, Uppsala, Suécia).

- Hitrap ${ }^{\mathrm{TM}} \mathrm{S}$ Sepharose FF $1 \mathrm{~mL}$ (GE Healthcare, Uppsala, Suécia).

- Proteína G Sepharose ${ }^{\mathrm{TM}} 4$ Fast Flow (GE Healthcare, Uppsala, Suécia).

- Q Sepharose ${ }^{\mathrm{TM}}$ Fast Flow (GE Healthcare, Uppsala, Suécia).

- S Sepharose ${ }^{\circledR} F F$ (GE Healthcare, Uppsala, Suécia).

\subsection{Soluções e materiais utilizados nos ensaios de caracterização}

- 3,3'Diaminobenzidine tetrahydrochloride (DAB) (Sigma-Aldrich, St. Louis, MO, EUA).

- Broad pl marker 3-10 (GE Healthcare, Uppsala, Suécia).

- Digitoxina (Sigma-Aldrich, St. Louis, MO, EUA).

- Digoxigenina (Sigma-Aldrich, St. Louis, MO, EUA).

- Digoxina (Sigma-Aldrich, St. Louis, MO, EUA). 
- HBS-EP: HEPES $10 \mathrm{mM}, \mathrm{NaCl} 150 \mathrm{mM}$, EDTA $3 \mathrm{mM}$, Tween 20 0,05\% $\mathrm{pH} 7,4$

- Kit Amersham ECL Plus Western Blotting Detection Reagents (GE Healthcare, EUA).

- Kit de imobilização covalente Amine Coupling (GE Healthcare, Uppsala, Suécia), contendo:

- EDC: hidrocloreto de 1-ethyl-3-(3-dimetilaminopropil) carbodiimida.

- NHS: N-Hidroxisuccinimida.

- LMW Calibration Kit for SDS Electrophoresis (GE Healthcare, Uppsala, Suécia).

- Membrana de PVDF (Millipore, EUA; GE Healthcare, Uppsala, Suécia).

- Microplaca MaxiSorp de 96 poços (Nunc Immuno ${ }^{\mathrm{TM}}$ Plates, Dinamarca).

- Ouabaina (Sigma-Aldrich, St. Louis, MO, EUA).

- Phast Gel ${ }^{\circledR}$ IEF 3-9 (GE Healthcare, Uppsala, Suécia)

- Sensor tipo CM5 (GE Healthcare, Uppsala, Suécia).

- Solução de sensibilização: carbonato de sódio $15 \mathrm{mM}$; bicarbonato de sódio $35 \mathrm{mM}, \mathrm{pH}$ 9,6.

- Solução reveladora: $10 \mathrm{~mL}$ de tampão acetato/ácido cítrico $0,1 \mathrm{M} \mathrm{pH} 6,0$; $100 \mu \mathrm{L}$ de 3,3',5,5'-tetrametilbenzidina (TMB) a $1 \%$ em dimetilsulfóxido (DMSO); $1,5 \mu \mathrm{L}$ de água oxigenada $31,5 \%$.

\subsection{Anticorpos utilizados nos ensaios de caracterização}

- Fragmento $F\left(a b^{\prime}\right)_{2}$ de coelho anti-IgG específico para $F\left(a b^{\prime}\right)_{2}$ de camundongo - 315-006-047 (Jackson ImmunoResearch Laboratories, West Grove, PA, EUA).

- Fragmento Fab de IgG de camundongo - 015-000-007 (Jackson ImmunoResearch Laboratories, West Grove, PA, EUA).

- Anticorpo de cabra anti-lgG de camundongo fragmento $F(a b)_{2}$ específico conjugado com peroxidase (Jackson ImmunoResearch Laboratories, West Grove, PA, EUA).

- Anticorpo de coelho anti-lgG de cabra conjugado com peroxidase - A4174 (Sigma-Aldrich, St. Louis, MO, EUA). 
- DigiFab $^{\circledR}$ (BTG, Londres, Inglaterra): Fragmento Fab policlonal anti-digoxina produzido em ovelha.

\subsection{Equipamentos}

- Äkta Purifier (GE Healthcare, Uppsala, Suécia).

- Biacore $^{\mathrm{TM}}$ - T200 (GE Healthcare, Uppsala, Suécia).

- Bomba peristáltica P50 (GE Healthcare Uppsala, Suécia).

- Cartucho de filtração tangencial - PrepScale 10 kDa (Millipore, EUA).

- Centrífuga 5804 R (Eppendorf AG, Alemanha).

- Centrífuga Beckman Avanti ${ }^{\mathrm{TM}}$ J-25 (Beckman, Fullerton, CA, EUA).

- Concentrador Spin X 10 kDa (Corning, NY, EUA).

- Espectrofotômetro Ultrospec 6300 pro (Amersham Biosciences, Uppsala, Suécia).

- Leitor de microplacas (Labsystem iEMS Analyzer, Finlândia) com o software de controle e análise Genesis Lite (Labsystems and Life Sciences International UK).

- Misturador térmico - Thermomixer compact (Eppendorf AG, Alemanha)

- Monitor UV com filtro de 280 nm (GE Healthcare Uppsala, Suécia).

- Phast System ${ }^{\text {TM }}$ (Pharmacia, Uppsala, Suécia)

- Registrador (GE Healthcare Uppsala, Suécia).

- Sistema de eletroforese Mini-PROTEAN ${ }^{\circledR}$ (Bio-Rad, EUA).

- Sistema de transferência semi-seca - Trans-Blot SD Semi-Dry Electrophoretic Transfer Cell (Bio-Rad, Hercules, CA, EUA).

- Ultrassom para lise celular (Microson ${ }^{\mathrm{TM}}$ Ultrasonic - (Misonix, Farmingdale, NY, EUA)

\subsection{Transformação por choque térmico}

Cinquenta microlitros de bactéria $E$. coli XL1-Blue foram incubados com $1 \mu \mathrm{L}$ de vetor por $10 \mathrm{~min}$ em gelo seguido de incubação por $45 \mathrm{~s}$ a $42{ }^{\circ} \mathrm{C}$ no aparelho Thermomixer compact e 5 min no gelo. Foram adicionados $450 \mu \mathrm{L}$ de meio SOC e a cultura foi incubada por $1 \mathrm{~h}$ a $37^{\circ} \mathrm{C}$, sob agitação. Dessa cultura $40 \mu \mathrm{L}$ foram plaqueados em placa de Petri contendo meio LB - ágar suplementado com 
ampicilina a $100 \mu \mathrm{g} / \mathrm{mL}$. Em seguida as placas foram incubadas a $37^{\circ} \mathrm{C}$ durante aproximadamente $18 \mathrm{~h}$.

\subsection{Expressão de fragmentos Fab anti-digoxina solúveis}

A expressão dos fragmentos Fab anti-digoxina no vetor pComb3X foi realizada conforme descrito por Murata et al. (2013) com algumas modificações. As 4 construções plasmidiais foram transformados em bactérias $E$. coli XL1-Blue por choque térmico, conforme descrito no item 3.6. Após o crescimento bacteriano as colônias foram coletadas e inoculadas em $60 \mathrm{~mL}$ de meio SB suplementado com cloreto de magnésio $20 \mathrm{mM}$ e ampicilina $100 \mu \mathrm{g} / \mathrm{mL}$, sendo incubadas a $37^{\circ} \mathrm{C}$ durante $2 \mathrm{~h}$ sob agitação de $210 \mathrm{rpm}$. Após a incubação, $8 \mathrm{~mL}$ do cultivo foram inoculados em frasco contendo $400 \mathrm{~mL}$ de meio SB com cloreto de magnésio $20 \mathrm{mM}$ e ampicilina $100 \mu \mathrm{g} / \mathrm{mL}$. Esta suspensão foi incubada a $37^{\circ} \mathrm{C}$ a $210 \mathrm{rpm}$ até a densidade óptica (DO) a $600 \mathrm{~nm}$ atingir entre 0,8 e 1,0. A expressão dos fragmentos Fab anti-digoxina foi induzida pela adição de IPTG $0,5 \mathrm{mM}$ ao cultivo e incubação a $30^{\circ} \mathrm{C}$, sob agitação de $210 \mathrm{rpm}$ durante aproximadamente $18 \mathrm{~h}$, que, por conveniência realizava-se durante a noite. Após este período, o cultivo foi centrifugado a $17700 \mathrm{xg}$ por $30 \mathrm{~min}$ a $4{ }^{\circ} \mathrm{C}$. O sobrenadante e o sedimento foram armazenados a $-80 \stackrel{\circ}{\circ}$ para verificar a presença de fragmentos Fab.

\subsection{Lise bacteriana}

O sobrenadante da cultura bacteriana foi dividido em 4 alíquotas contendo 50 $\mathrm{mL}$ cada e centrifugado a $5400 \times \mathrm{g}$. Os sedimentos bacterianos das 4 alíquotas foram lisados em um protocolo para a lise total e em 3 protocolos diferentes para a lise do espaço periplasmático.

\subsubsection{Lise bacteriana total por ultrassom}

O sedimento do cultivo foi ressuspendido em 2,5 mL de PBS estéril e lisado por sonicação com 10 pulsos de $10 \mathrm{~s}$, intercalado entre um pulso e outro por incubação de 2 min em gelo. A suspensão foi centrifugada a $15500 \times$ g por $30 \mathrm{~min}$ a $4{ }^{\circ} \mathrm{C}$, sendo o sobrenadante armazenado a $-20^{\circ} \mathrm{C}$. 


\subsubsection{Lise do periplasma bacteriano por choque osmótico}

\subsubsection{Lise periplasma protocolo 1 (THORSTENSON et al.,1997)}

O sedimento bacteriano foi ressuspendido em $5 \mathrm{~mL}$ de sacarose $500 \mathrm{mM}$; Tris $200 \mathrm{mM}$; EDTA 0,5 mM e incubado em gelo por $15 \mathrm{~min}$. Após a incubação foram adicionados $20 \mathrm{~mL}$ do tampão Tris $10 \mathrm{mM}$ pH 8,0; EDTA $1 \mathrm{mM}$, seguido de incubação em gelo por $30 \mathrm{~min}$. Ao final o material foi centrifugado a $5400 \times \mathrm{g}$ por 10 min a $4{ }^{\circ} \mathrm{C}$. O sobrenadante foi armazenado a $-20^{\circ} \mathrm{C}$.

\subsubsection{Lise periplasma protocolo 2 (Sigma Flag ${ }^{\circledR}$ E. coli Expression system manual)}

Para ressuspender o sedimento bacteriano, foram adicionados $40 \mathrm{~mL}$ da solução de sacarose $500 \mathrm{mM}$; Tris $30 \mathrm{mM}$; EDTA $1 \mathrm{mM} \mathrm{pH} \mathrm{8,0} \mathrm{para} \mathrm{cada} \mathrm{grama} \mathrm{de}$ bactéria, seguido pela centrifugação a $5400 \times \mathrm{g}$ por $10 \mathrm{~min}$ a $10^{\circ} \mathrm{C}$. Após a centrifugação o sobrenadante foi separado e o sedimento ressuspendido em $20 \mathrm{~mL}$ de água purificada gelada para cada grama de bactéria e centrifugado a $5400 \times \mathrm{g}$ por 10 min a $4{ }^{\circ} \mathrm{C}$. Os sobrenadantes obtidos nas duas etapas foram misturados $\mathrm{e}$ armazenados $\mathrm{a}-20^{\circ} \mathrm{C}$.

\subsubsection{Lise periplasma protocolo 3 (ROUET et al., 2012)}

Foram adicionados 2,5 mL do tampão sacarose $20 \%$; Tris $100 \mathrm{mM}$; EDTA $1 \mathrm{mM}$ pH 8,0 gelado para ressuspender o sedimento bacteriano. Esta suspensão foi incubada em gelo por 30 min. Após a incubação a suspensão foi centrifugada a $5400 \mathrm{xg}$ por $10 \mathrm{~min}$ a $10^{\circ} \mathrm{C}$. O sobrenadante foi separado e $\mathrm{O}$ sedimento ressuspendido em $2,5 \mathrm{~mL}$ de cloreto de magnésio $5 \mathrm{mM}$ e incubado por $20 \mathrm{~min}$ em gelo. Depois da incubação o material foi centrifugado a $5400 \times \mathrm{g}$ por 10 min a $4{ }^{\circ} \mathrm{C}$. Os sobrenadantes obtidos nas duas etapas foram misturados e armazenados a $-20^{\circ} \mathrm{C}$. 


\subsection{Purificação}

\subsubsection{Cromatografia líquida em resina de afinidade Proteína $L$}

Para a purificação o sobrenadante foi descongelado, dialisado com solução salina fosfatada (PBS) e concentrado por filtração tangencial em cartucho PrepScale $10 \mathrm{kDa}$.

O ensaio foi realizado com resina pré-empacotada HiTrap ${ }^{\mathrm{TM}}$ Proteina $\mathrm{L} 1 \mathrm{~mL}$, conectada ao sistema automatizado Äkta Purifier. Para o equilíbrio da coluna utilizou-se tampão fosfato de sódio $20 \mathrm{mM}, \mathrm{NaCl} 150 \mathrm{mM}, \mathrm{pH}$ 7,0. A amostra a ser purificada foi injetada na coluna, ao final da injeção passou-se o tampão de equilíbrio para remover possíveis ligações inespecíficas e reequilibrar a coluna. Para eluição optou-se pelo uso de um gradiente de $\mathrm{pH}$ com a utilização dos tampões: A - citrato de sódio $100 \mathrm{mM} \mathrm{pH} \mathrm{3,5} \mathrm{e} \mathrm{B} \mathrm{-} \mathrm{ácido} \mathrm{cítrico} 100 \mathrm{mM} \mathrm{pH} \mathrm{2,0} \mathrm{nas} \mathrm{condições} \mathrm{de} 0$ a $100 \%$ de B, em 20 volumes de coluna. A regeneração da coluna foi realizada com a passagem de hidróxido de sódio $15 \mathrm{mM}$ e repouso de $10 \mathrm{~min}$ de contato. $\mathrm{O}$ enxágue do tampão de regeneração foi realizado com o tampão de equilíbrio, em seguida a resina foi armazenada em solução de álcool etílico $20 \%$. O fluxo utilizado nas etapas foi de $1 \mathrm{~mL} / \mathrm{min}$ em temperatura ambiente.

\subsubsection{Cromatografia líquida em resina de afinidade Proteína G}

Os sobrenadantes foram tratados, conforme descrito no item 3.9.1, ou através de uma etapa de diálise contra PBS para os fragmentos Fab obtidos pela lise do espaço periplasmático. Após o tratamento o material a ser purificado foi aplicado em $5 \mathrm{~mL}$ de resina proteína G Sepharose ${ }^{T M} 4$ FF empacotada em coluna C10/10 de $1 \mathrm{~cm}$ de diâmetro $\times 10 \mathrm{~cm}$ de altura e a coluna foi acoplada a um sistema de bomba peristáltica, monitor UV $280 \mathrm{~nm}$ e registrador. A coluna foi equilibrada com o tampão Tris $50 \mathrm{mM}, \mathrm{NaCl} 150 \mathrm{mM}, \mathrm{pH} 7,0$. Posteriormente o sobrenadante da cultura contendo $25 \%(\mathrm{v} / \mathrm{v})$ da solução de equilíbrio foi aplicado à coluna. Após o carregamento, passou-se pela coluna a solução de equilíbrio para remover possíveis ligações inespecíficas. A eluição foi realizada com o tampão ácido acético $200 \mathrm{mM}$ pH 3,0. O eluato foi neutralizado com a adição de Tris $1 \mathrm{M}$ com quantidade suficiente para elevar $\mathrm{opH}$ a 7,0 e dialisado duas vezes contra PBS durante $18 \mathrm{~h}$. A regeneração da coluna foi realizada com tampão ácido acético $1 \mathrm{M} \mathrm{pH} 2,5$. Na etapa 
de carregamento foi utilizado o fluxo de $0,5 \mathrm{~mL} / \mathrm{min}$ e as demais etapas foram realizadas com fluxo de $1 \mathrm{~mL} / \mathrm{min}$ a $4 \stackrel{\circ}{\circ}$.

\subsubsection{Ensaios de otimização da purificação dos fragmentos Fab anti-digoxina}

Os ensaios cromatográficos foram realizados com a utilização do sistema automatizado Äkta Purifier em temperatura ambiente ou com o uso de bomba peristáltica, monitor UV $280 \mathrm{~nm}$ e registrador com temperatura de $4-8 \stackrel{\circ}{\circ}$. Devido ao processo de purificação possuir as mesmas etapas descritas nos itens 3.9.1 e 3.9.2 são apresentados apenas os tampões utilizados em cada etapa.

\subsubsection{Cromatografia líquida em resina de proteína G FF}

\subsection{Proteína G - Protocolo 1}

Foi utilizada a mesma estratégia cromatográfica descrita no item 3.9.2

\subsection{Proteína G - Protocolo 2}

O sobrenadante foi diafiltrado com o tampão glicina 1,5 M, NaCl $150 \mathrm{mM}$ pH 9,0 e concentrado por filtração tangencial em cartucho PrepScale 10 kDa. Para o equilíbrio da resina e reequilíbrio após a aplicação da amostra utilizou-se o tampão glicina $1,5 \mathrm{M}, \mathrm{NaCl} 3 \mathrm{M}, \mathrm{pH} 9,0$, seguido pela eluição $1 \mathrm{com}$ o tampão citrato de sódio $50 \mathrm{mM}, \mathrm{NaCl} 150 \mathrm{mM}, \mathrm{pH} 6,0$ e eluição $2 \mathrm{com}$ o tampão citrato de sódio $50 \mathrm{mM}, \mathrm{NaCl} 150 \mathrm{mM}, \mathrm{pH} 3,0$. A regeneração da resina foi realizada pela passagem dos tampões glicina $50 \mathrm{mM}, \mathrm{NaCl} 150 \mathrm{mM}, \mathrm{pH} 2,3$ e do tampão tris $50 \mathrm{mM}, \mathrm{NaCl} 1 \mathrm{M}, \mathrm{pH} 8,6$.

\subsection{Proteína $G$ - Protocolo 3}

Para o equilíbrio e reequilíbrio da resina foi utilizada a solução de fosfato de

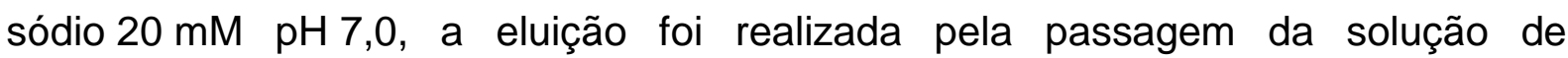
glicina 100 mM pH 2,7 e para a regeneração da resina foi aplicada a solução ácido acético $1 \mathrm{M} \mathrm{pH}$ 2,4. As frações correspondentes aos eluatos foram dialisadas com a solução de acetato de sódio 20 mM pH 4,5. 


\subsubsection{Cromatografia em resina S Sepharose FF}

\subsection{S Sepharose - Protocolo 1}

A amostra a ser purificada era diafiltrada com o tampão acetato de sódio $50 \mathrm{mM} \mathrm{pH} \mathrm{5,0} \mathrm{e} \mathrm{concentrado} \mathrm{por} \mathrm{filtração} \mathrm{tangencial} \mathrm{em} \mathrm{cartucho} \mathrm{PrepScale}$ $10 \mathrm{kDa}$, ou pelo uso de concentradores Spin X $10 \mathrm{kDa}$. A resina pré-empacotada contendo $1 \mathrm{~mL}$ de resina S Sepharose FF - Hitrap $1 \mathrm{~mL}$ foi equilibrada e lavada após

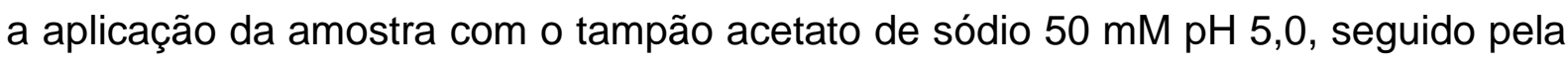
eluição em gradiente de $\mathrm{NaCl}$ com a utilização dos tampões: A - acetato de sódio $50 \mathrm{mM}$ pH 5,0 e B - acetato de sódio $50 \mathrm{mM}, \mathrm{NaCl} 1 \mathrm{M}$ nas condições de 0 a $100 \%$ de $\mathrm{B}$, em 20 volumes de coluna. A regeneração da resina foi realizada pela passagem de $\mathrm{NaOH} 0,1 \mathrm{M}$.

\subsection{S Sepharose - Protocolo 2}

O sobrenadante do cultivo foi diluído por aproximadamente 4 vezes com a adição do tampão acetato de sódio $15 \mathrm{mM} \mathrm{pH} \mathrm{5,0} \mathrm{para} \mathrm{atingir} \mathrm{a} \mathrm{condutividade} \mathrm{de}$ $5,0 \mathrm{mS} / \mathrm{cm}$, o pH foi ajustado para 5,0 com a adição de $\mathrm{HCl} 6 \mathrm{~N}$, sendo filtrado em $0,45 \mu \mathrm{m}$, posteriormente. A resina S Sepharose FF foi empacotada em coluna XK 26/20 com 2,6 cm de diâmetro $\times 20 \mathrm{~cm}$ de altura, o volume de resina obtido após o empacotamento foi de $40 \mathrm{~mL}$. Para o equilíbrio da resina e reequilíbrio após a

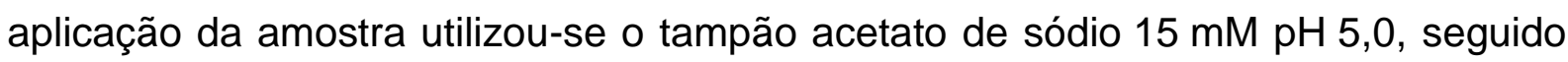
pela eluição $1 \mathrm{com}$ tampão fosfato de sódio $20 \mathrm{mM} \mathrm{pH} \mathrm{7,0} \mathrm{e} \mathrm{eluição} 2$ com tampão fosfato de sódio $20 \mathrm{mM}, \mathrm{NaCl} 1,5 \mathrm{M} \mathrm{pH} 7,0$. A regeneração da resina foi realizada pela passagem de $\mathrm{NaOH} 0,1 \mathrm{M}$.

\subsubsection{Cromatografia em resina $Q$ Sepharose}

O sobrenadante do cultivo foi centrifugado a $17700 \times \mathrm{g}$, filtrado a $0,45 \mu \mathrm{m}$ e adicionado de Tween 20 para a concentração final de $0,05 \%$, seguido pela injeção da amostra à coluna cromatográfica com $5 \mathrm{~mL}$ de resina $Q$ Sepharose ${ }^{\mathrm{TM}} \mathrm{FF}$ empacotada em coluna $\mathrm{C} 10 / 10$ de $1 \mathrm{~cm}$ de diâmetro $\times 10 \mathrm{~cm}$ de altura, contendo $6,8 \mathrm{~cm}$ de leito de resina. A resina foi equilibrada e reequilibrada após a aplicação da amostra com o tampão Tris $20 \mathrm{mM}$ pH 7,0. A eluição foi realizada com o tampão 
Tris $20 \mathrm{mM}, \mathrm{NaCl} 200 \mathrm{mM} \mathrm{pH} \mathrm{7,0.} \mathrm{Para} \mathrm{a} \mathrm{regeneração} \mathrm{da} \mathrm{resina} \mathrm{foram} \mathrm{utilizados} \mathrm{os}$ tampões Tris $20 \mathrm{mM} \mathrm{NaCl} 1 \mathrm{M}$ e ácido acético $1 \mathrm{M} \mathrm{pH} 2,5$.

\subsection{Quantificação dos fragmentos Fab solúveis}

\subsubsection{Enzyme-linked immunosorbent assay (ELISA) - Método 1}

Em microplaca MaxiSorp de 96 poços realizou-se a sensibilização da placa com a adição de $100 \mu \mathrm{L}$ por poço da solução sensibilizadora contendo o fragmento $F\left(a b^{\prime}\right)_{2}$ de coelho anti-IgG específico para $F\left(a b^{\prime}\right)_{2}$ de camundongo, a $1,5 \mu \mathrm{g} / \mathrm{mL}$. A microplaca foi incubada em câmara úmida por aproximadamente $18 \mathrm{~h}$ a $4^{\circ} \mathrm{C}$. No dia seguinte a placa foi lavada com PBS-Tween 20 0,05\% por 3 vezes, bloqueada com $300 \mu \mathrm{L}$ de PBS-leite desnatado $10 \%$ e incubada por $2 \mathrm{~h}$ a temperatura ambiente. Após o bloqueio, a placa foi lavada com PBS-Tween 20 0,05\% por 3 vezes.

A curva-padrão foi preparada com o fragmento Fab de IgG de camundongo, com concentração inicial de $0,176 \mu \mathrm{g} / \mathrm{mL}$ diluído em PBS-leite desnatado $5 \%$. Os fragmentos Fab foram diluídos em concentração apropriada em PBS-leite desnatado $5 \%$. Após a diluição inicial da curva-padrão e dos fragmentos Fab anti-digoxina a serem quantificados, procedeu-se à diluição seriada das mesmas na razão de 1:2, em placa de apoio e a posterior transferência de $100 \mu \mathrm{L}$ de cada poço para a placa sensibilizada, seguida de incubação em câmara úmida a $37^{\circ} \mathrm{C}$ por $1 \mathrm{~h}$. Após a incubação a placa foi lavada com PBS-Tween 20 0,05\% por 3 vezes. Foram adicionados $100 \mu \mathrm{L}$ por poço do anticorpo de cabra anti-lgG de camundongo fragmento $\mathrm{F}\left(\mathrm{ab} \mathrm{b}_{2}\right)_{2}$ específico conjugado com peroxidase, diluído 1:7000 em PBS-leite desnatado $5 \%$ para incubação em câmara úmida a $37^{\circ} \mathrm{C}$ por $1 \mathrm{~h}$. A placa foi lavada com PBS-Tween $200,05 \%$ por 3 vezes. Foram adicionados $100 \mu \mathrm{L}$ da solução reveladora a cada poço, seguido pela incubação da placa por $20 \mathrm{~min}$ a temperatura ambiente, ao abrigo de luz. A reação foi interrompida com a adição de $50 \mu \mathrm{L}$ de $\mathrm{H}_{2} \mathrm{SO}_{4} 4,7 \mathrm{~N}$. A medida da absorbância a $450 \mathrm{~nm}$ foi realizada em leitor de placas com o software de controle e análise Genesis Lite. O cálculo das concentrações foi efetuado pela interpolação da curva padrão. $O$ ajuste da curva padrão utilizado foi método dos quatro parâmetros realizado pelo software Genesis. 


\subsubsection{Dosagem de proteína pela Absorbância 280 nm}

Para a quantificação dos fragmentos Fab anti-digoxina purificados por absorbância foi utilizado o espectrofotômetro Ultrospec 6300 pro. Para tanto, $80 \mu \mathrm{L}$ das amostras, foram colocados em cubeta de quartzo com caminho ótico de $1 \mathrm{~cm}$ e procedido a medida da absorbância a $280 \mathrm{~nm}$. Como branco foi utilizado PBS ou tampão acetato de sódio $20 \mathrm{mM}$ pH 4,5. O coeficiente de absorção molar $(\varepsilon)$ utilizado para os fragmentos Fab foi de 1,53 (ANDREW; TITUS, 2000). Para a obtenção das concentrações em $\mathrm{mg} / \mathrm{mL}$ utilizou-se a seguinte fórmula: $C=A / \varepsilon$, onde C: concentração, A: absorbância e $\varepsilon$ : coeficiente de absorção molar.

\subsubsection{Dosagem dos fragmentos Fab por ressonância plasmônica de superfície - SPR}

A concentração do fragmento $\mathrm{Fab}$ (analito) foi determinada utilizando o equipamento Biacore ${ }^{\mathrm{TM}}$ - T200. O conjugado Dig-BSA foi imobilizado no sensor tipo CM5 (célula de fluxo 4) por ligação do tipo amina. Para tanto, foram usados os reagentes do kit de imobilização covalente Amine Coupling: EDC, NHS e etanolamina $1 \mathrm{M}-\mathrm{HCl}$ pH 8,5. O conjugado Dig-BSA foi diluído em tampão acetato de

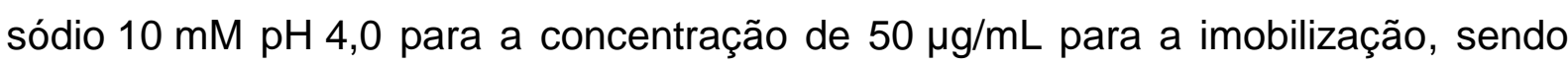
obtida $8779 \mathrm{RU}$ (unidades de ressonância). Como controle negativo foi realizada a imobilização de BSA no sensor (célula de fluxo 3), nas mesmas condições realizadas para o Dig-BSA.

A curva padrão foi preparada partindo-se de uma solução estoque de

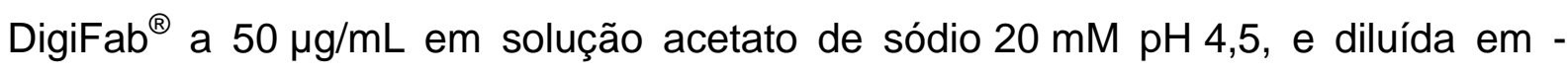
tampão de corrida - HBS-EP nas seguintes concentrações: 0, 2, 4, 8 e $10 \mu \mathrm{g} / \mathrm{mL}$. Como controle positivo para garantir a reprodutibilidade do ensaio utilizou-se uma solução de DigiFab ${ }^{\oplus}$ com $5 \mu \mathrm{g} / \mathrm{mL}$. As amostras foram diluídas 1:10, na mesma solução tampão que a curva padrão.

O ensaio foi realizado a $37^{\circ} \mathrm{C}$, fluxo de $10 \mu \mathrm{L} / \mathrm{min}$, tempo de contato de $180 \mathrm{~s}$. A concentração dos analitos foi verificada $5 \mathrm{~s}$ após o término da injeção dos mesmos. A regeneração foi realizada com a passagem de um pulso de $20 \mu \mathrm{L}$ da solução de SDS 0,5\%, glicina $100 \mathrm{mM} \mathrm{pH} \mathrm{2,0.}$ 


\subsection{Ensaios analíticos}

\subsubsection{Eletroforese em gel de poliacrilamida com dodecil sulfato de sódio (SDS- PAGE)}

As corridas eletroforéticas foram realizadas com géis de poliacrilamida com concentração de 12\%, com espessura de 0,75 mm. Quando necessário, as amostras foram diluídas em PBS e preparadas com tampão de amostra com ou sem agente redutor ( $\beta$-Mercaptoetanol). Como marcador de massa molecular foi utilizado - LMW Calibration Kit for SDS Electrophoresis. O sistema utilizado foi o MiniPROTEAN ${ }^{\Theta}$. A coloração foi realizada por nitrato de prata ou corante Azul de Coomassie R250.

\subsubsection{Determinação do ponto isoelétrico}

A determinação do ponto isoelétrico (pl) dos fragmentos Fab anti-digoxina foi realizada pelo ensaio de focalização isoelétrica realizado no equipamento automatizado Phast System ${ }^{\mathrm{TM}}$, com o uso de gel de poliacrilamida Phast Ge ${ }^{\circledR}$ IEF 3-9 com faixa de $\mathrm{pH}$ entre 3 a 9, próprio para o equipamento. Como marcador de ponto isoelétrico foi utilizado o Broad pl marker 3-10.

O método utilizado é composto pelas etapas de pré-focalização (formação do gradiente de $\mathrm{pH}$ no gel) realizada a $15^{\circ} \mathrm{C}$ com voltagem de $2000 \mathrm{~V}$ e duração de $75 \mathrm{Vh}$, seguida pela aplicação da amostra a $15^{\circ} \mathrm{C}, 200 \mathrm{~V}$ e $15 \mathrm{Vh}$, finalizando pela etapa de focalização realizada a $15^{\circ} \mathrm{C}, 2000 \mathrm{~V}$ e $410 \mathrm{Vh}$. Ao término da focalização das amostras o gel foi submetido à coloração por nitrato de prata.

\subsubsection{Western Blotting}

Para a imunodetecção dos fragmentos Fab purificados dos 4 clones, as amostras foram aplicadas em dois géis idênticos de poliacrilamida a $12 \%$ e submetidas à corrida eletroforética.

No gel referência realizou-se a coloração por prata, o segundo gel foi transferido para uma membrana de PVDF com a utilização do sistema Trans-Blot SD Semi-Dry Electrophoretic Transfer Cell, com voltagem de $10 \mathrm{~V}$ e tempo de transferência de $30 \mathrm{~min}$. Após a transferência, realizou-se o bloqueio da membrana com PBS-leite desnatado a $10 \%$ e incubação por $2 \mathrm{~h}$ em temperatura ambiente. 
Após o bloqueio a membrana foi lavada 4 vezes com PBS Tween 20 0,05\% e realizada a imunodetecção com a incubação das membranas com o anticorpo de cabra anti-IgG de camundongo fragmento $F\left(a b{ }^{\prime}\right)_{2}$ específico, conjugado com peroxidase, diluído 1:15000 em PBS-leite desnatado $5 \%$, por $1 \mathrm{~h}$ em temperatura ambiente. Após a incubação do anticorpo conjugado com peroxidase a membrana foi lavada 4 vezes com PBS Tween 20 0,05\% e revelada com DAB ou pela utilização do kit Amersham ECL Plus Western Blotting Detection Reagents.

Para a análise da ligação dos fragmentos Fab ao antígeno, amostras de Dig-BSA e BSA foram aplicadas em géis de poliacrilamida $12 \%$ e submetidos à eletroforese. O gel referência foi corado por Coomassie e os outros géis foram transferidos para a membrana PVDF, como descrito anteriormente. Após o bloqueio, cada membrana foi incubada com o fragmento Fab anti-digoxina de cada clone e do DigiFab $^{\circledR}$ diluídos para $0,25 \mu \mathrm{g} / \mathrm{mL}$ em PBS-leite desnatado $5 \%$ por $1 \mathrm{~h}$ a $37^{\circ} \mathrm{C}$. A imunodetecção da membrana incubada com $\circ$ DigiFab $^{\circledR}$ foi realizada com a utilização do anticorpo de coelho anti-lgG de cabra conjugado com peroxidase, diluído 1:10000 em PBS-leite desnatado 5\%. A imunodetecção das membranas incubadas com os fragmentos dos 4 clones e a revelação de todas as membranas foram realizadas conforme descrito acima.

\subsubsection{Ensaio de ligação dos clones Fab anti-digoxina ao antígeno pelo teste de ELISA - Método 2}

A metodologia foi realizada conforme descrito no item 3.10.1. Com as seguintes modificações:

- Sensibilização da placa com Dig-BSA ou BSA (controle negativo) na concentração de $4 \mu \mathrm{g} / \mathrm{mL}$;

- Diluição dos fragmentos Fab purificados à concentração inicial de 1 nM;

- Anticorpo de cabra anti-lgG de camundongo fragmento $F\left(a b^{\prime}\right)_{2}$ específico, conjugado com peroxidase, diluído 1:5000.

\subsubsection{ELISA de inibição da ligação entre os fragmentos anti-digoxina e a Dig- BSA pela digoxina e seus análogos - Método 3.}

As microplacas foram sensibilizadas com Dig-BSA na concentração de $4 \mu \mathrm{g} / \mathrm{mL}$, conforme descrito no item 3.10.1. 
Como inibidores da ligação foram utilizados: digoxina, digitoxina, digoxigenina e ouabaina. Como diluente para o ensaio foi utilizado PBS-leite desnatado $5 \%$. As concentrações iniciais e os fatores das diluições seriadas foram ajustados, para a obtenção das curvas de $I_{50}$ (Tabela 2). A diluição seriada dos inibidores foi realizada em uma placa de apoio. Setenta microlitros de cada diluição dos inibidores foram misturadas com $70 \mu \mathrm{L}$ dos fragmentos Fab anti-digoxina a $1 \mathrm{nM}$, em uma segunda placa de apoio e homogeneizados por 10 vezes. Os fragmentos Fab foram avaliados em duplicata.

A mistura contendo o inibidor e fragmento Fab anti-digoxina foi transferida para a placa sensibilizada, seguindo com metodologia descrita no item 3.10.1. Com as seguintes modificações:

- Anticorpo de cabra anti-lgG de camundongo fragmento $F\left(a b^{\prime}\right)_{2}$ específico, conjugado com peroxidase, diluído 1:5000, para os fragmentos Fab dos 4 clones.

- Anticorpo de coelho anti-lgG de cabra conjugado com peroxidase, diluído 1:5000, para o DigiFab ${ }^{\circledR}$.

Tabela 2 - Concentração inicial dos inibidores e fator de diluição seriada.

\begin{tabular}{lccc}
\hline \multicolumn{1}{c}{ Inibidor } & $\begin{array}{c}\text { Concentração Inicial } \\
\mu \mathrm{M}\end{array}$ & $\begin{array}{c}\text { Concentração Final } \\
\mu \mathrm{M}\end{array}$ & $\begin{array}{c}\text { Fator de diluição } \\
\text { seriada }\end{array}$ \\
\hline Digoxina & 0,36 & $3,64 \times 10^{-8}$ & 10 \\
Digitoxina & 20 & $2,00 \times 10^{-6}$ & 10 \\
Digoxigenina & 1,1 & $6,44 \times 10^{-9}$ & 15 \\
Ouabaína & 1370 & $4,89 \times 10^{-3}$ & 6 \\
\hline
\end{tabular}

O cálculo da porcentagem de inibição foi realizado com a utilização da seguinte fórmula:

$$
\left(\frac{\text { DOmáxima }- \text { DOamostra }}{\text { DOmáxima }}\right) * 100=\%
$$

onde:

$D O_{\text {máxima }}=$ Absorbância obtida sem a adição de inibidor

$D O_{\text {amostra }}=$ Absorbância obtida pela adição de cada inibidor

A concentração necessária para inibir $50 \%$ da ligação do fragmento $\mathrm{Fab}\left(\mathrm{IC}_{50}\right)$ foi calculada com a utilização do programa GraphPad PRISM ${ }^{\circledR}$ Version 5.00, através 
dos seguintes parâmetros: ajuste da curva por regressão não linear e análise pela opção dose resposta sigmoide (declive variável).

\subsubsection{Determinação de parâmetros cinéticos por SPR}

Com a utilização do equipamento Biacore ${ }^{\circledR}$ T200 (GE Healthcare), os parâmetros cinéticos de ligação dos fragmentos Fab anti-digoxina purificados dos 4 clones e do DigiFab $^{\circledR}$ (analitos) com o conjugado Dig-BSA (ligante) foram determinados.

Para o ensaio foi utilizado o mesmo sensor imobilizado com Dig-BSA utilizado para a quantificação dos fragmentos Fab anti-digoxina (item 3.10.3).

A análise da cinética da ligação foi realizada nas seguintes condições:

- Concentrações das amostras: 0; 0,625; 1,25; 2,5 e 5,0 $\mu \mathrm{g} / \mathrm{mL}$ em solução HBS-EP.

- Cinética em ciclo único, a $37^{\circ} \mathrm{C}$, fluxo de $30 \mu \mathrm{L} / \mathrm{min}$, tempo de contato de $120 \mathrm{~s}$ e dissociação por $720 \mathrm{~s}$.

- Regeneração com a passagem de um pulso de $20 \mu \mathrm{L}$ da solução de SDS 0,5\%, glicina $100 \mathrm{mM} \mathrm{pH} 2,0$.

- Ajuste da curva conforme o modelo de Langmuir (1:1 - ligação entre uma molécula do analito com uma do ligante). 


\section{RESUltados}

\subsection{Expressão dos fragmentos Fab anti-digoxina em E. coli}

Para a expressão dos fragmentos Fab anti-digoxina dos 4 clones o DNA plasmidial de cada clone foi transformado em bactérias E. coli da linhagem XL1Blue. Para a indução da expressão do Fab solúvel foi adicionado IPTG ao cultivo bacteriano, conforme descrito em Materiais e Métodos. Os fragmentos Fab podem ser obtidos do sobrenadante de cultivo, pelo uso de bactérias supressoras e também ficam retidos no espaço periplasmático. Qual a fonte a explorar para a purificação dos fragmentos Fab constituiu o primeiro ponto de decisão. Para tanto foi escolhido um clone, de número 10, com base nos resultados da análise inicial dos fragmentos no sobrenadante bruto (MURATA et al., 2013).

\subsection{Avaliação da presença do fragmento Fab intracelular e no sobrenadante do cultivo bacteriano}

A avaliação da presença do fragmento Fab solúvel anti-digoxina do clone 10 expresso pelo cultivo bacteriano foi realizada através de Western blotting. Foram analisadas amostras do sobrenadante e do sedimento bacteriano oriundo de $50 \mathrm{~mL}$ de cultivo que foram lisados por ultrassom (lise total) ou por choque osmótico (lise do periplasma) oriundos de 3 protocolos diferentes. As amostras foram aplicadas no gel de SDS-PAGE 12\% sem diluição. Verificou-se a existência de 2 componentes de massa molecular em todas as amostras analisadas, uma com massa molecular aproximada de $50 \mathrm{kDa}$, correspondente ao fragmento Fab anti-digoxina e outra de aproximadamente $25 \mathrm{kDa}$, que é o tamanho da cadeia leve ou pesada na forma reduzida (Figura 6). 
Figura 6 - Western blotting para verificação da presença dos fragmentos Fab antidigoxina no sobrenadante do cultivo celular, no periplasma e no sobrenadante do lisado bacteriano total.

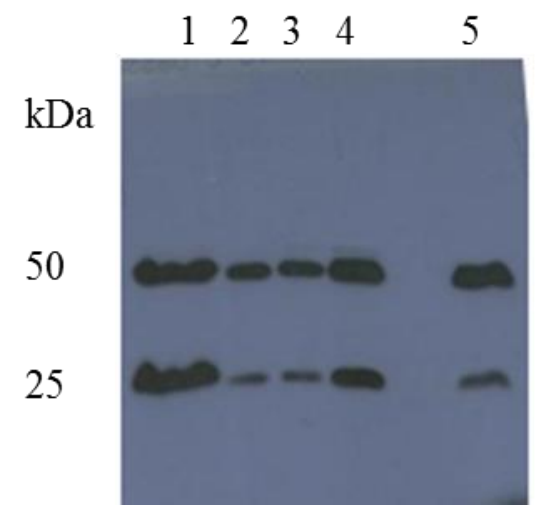

Foram aplicados $20 \mu \mathrm{L}$ das amostras em gel de poliacrilamida $12 \%$, seguido pelo Western blotting. A imunodetecção foi realizada com incubação da membrana com o anticorpo anti-lgG de camundongo específico para fragmento $\mathrm{F}\left(\mathrm{ab} \mathrm{b}_{2}\right)_{2}$ conjugado com peroxidase e detectado com o sistema $E C L$. Poços: 1- sobrenadante do cultivo bacteriano; 2- lise periplasma protocolo 1; 3- lise periplasma protocolo 2; 4- lise periplasma protocolo 3; 5- lise bacteriana total

Com o intuito de verificar o perfil das amostras que contém o fragmento Fab, foi realizada eletroforese em gel de poliacrilamida a $12 \%$, onde as amostras foram diluídas para a concentração de $1 \mu \mathrm{g} / \mathrm{mL}$ do fragmento Fab anti-digoxina (Figura 7).

Figura 7 - SDS-PAGE (12\%), corado por prata, das amostras que contém fragmento Fab anti-digoxina do clone 10.

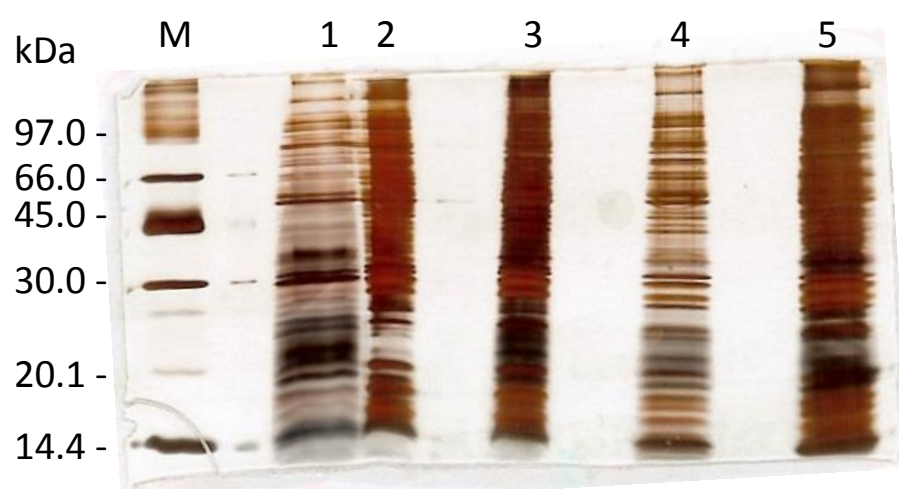

Foram aplicados a cada poço $20 \mu \mathrm{L}$ de amostra a $1 \mu \mathrm{g} / \mathrm{mL}$ do fragmento Fab anti-digoxina. Poços: $\mathrm{M}$ - marcador de baixo peso molecular; 1- sobrenadante do cultivo bacteriano; 2- lise periplasma protocolo 1; 3- lise periplasma protocolo 2; 4- lise periplasma protocolo 3; 5- lise bacteriana total.

Confirmada a presença do fragmento Fab anti-digoxina em todas as condições avaliadas, a concentração do anticorpo foi determinada pelo método de ELISA (método 1). A maior concentração de fragmento Fab foi obtida no 
sobrenadante do cultivo bacteriano: 114,50 ug. Não foram observadas diferenças significativas nas demais amostras (Tabela 3). Ainda que aparentemente metade do conteúdo esteja presente com massa de $25 \mathrm{kDa}$, ainda se trata da amostra com maior representação. Com a verificação da maior quantidade do fragmento Fab antidigoxina no sobrenadante do cultivo bacteriano (Tabela 3) optou-se pela sua utilização na avaliação das estratégias cromatográficas.

Tabela 3 - Concentração do fragmento Fab anti-digoxina do clone 10, obtida por ELISA, presente no sobrenadante da cultura de E. coli, periplasma e no lisado bacteriano total, a partir de $50 \mathrm{~mL}$ de cultura.

\begin{tabular}{lccc}
\hline & $\begin{array}{c}\text { Concentração } \\
\boldsymbol{\mu g} / \mathbf{m L}\end{array}$ & $\begin{array}{c}\text { Volume } \\
\mathbf{~} \mathbf{L}\end{array}$ & $\boldsymbol{\mu \mathbf { g }}$ /Totais \\
\hline Sobrenadante da cultura & 2,3 & 50 & 114,5 \\
Lise periplasma - protocolo 1 & 1,1 & 25 & 28,5 \\
Lise periplasma - protocolo 2 & 1,0 & 23 & 23,2 \\
Lise periplasma - protocolo 3 & 4,9 & 5 & 24,5 \\
Lise bacteriana total & 14,8 & 2 & 29,6 \\
\hline
\end{tabular}

\subsection{Purificação dos fragmentos Fab anti-digoxina expressos em E. coli}

A utilização da resina de afinidade pré-empacotada com $1 \mathrm{~mL}$ Hitrap protein $\mathrm{L}$ foi a primeira escolha, por ser uma resina com especificidade para a cadeia leve, que se encontra completa no fragmento Fab. Tem a capacidade de interagir com a cadeia leve do tipo Kappa dos anticorpos, permitindo o seu uso na purificação de fragmentos de anticorpos. Para tanto, o sobrenadante da cultura do clone 10 foi diafiltrado contra PBS e concentrado 7,7 vezes. A coluna foi carregada com $39 \mathrm{~mL}$ do material inicial. Através da análise do cromatograma, não foram observados picos a $280 \mathrm{~nm}$, durante a eluição, regeneração ou enxágue da coluna, indicando que o material alvo não foi adsorvido pela resina, possivelmente saindo na fração não ligada durante o carregamento.

Outra estratégia cromatográfica avaliada foi a utilização da resina de afinidade proteína G. A coluna foi carregada com $160 \mathrm{~mL}$ do sobrenadante da cultura bacteriana do mesmo clone 10. O eluato recuperado da cromatografia foi dialisado contra PBS e concentrado 21 vezes e avaliado para a presença do fragmento. Foram preparados 3 géis de poliacrilamida a $12 \%$, dos quais 2 géis foram corados, um por Coomassie (Figura 8a) e o outro por prata (Figura 8b). O terceiro gel foi 
transferido para membrana de PVDF para a verificação da ligação entre a amostra do eluato e o anticorpo anti-IgG de camundongo específico para o fragmento $F\left(a b^{\prime}\right)_{2}$ (Figura 8c). Como se pode observar nas Figuras $8 \mathrm{a}$ e 8b, no poço 4 dos géis o fragmento Fab anti-digoxina aparece puro pela coloração de Coomassie e com bandas adicionais pela coloração mais sensível de prata. A comparação do eluato com a amostra inicial carregada na coluna (poço 1) evidencia a capacidade desta etapa de cromatografia para a purificação do fragmento anti-digoxina. O resultado do Western blotting confirmou a capacidade de ligação entre o fragmento Fab antidigoxina purificado e o anticorpo anti-lgG de camundongo específico para 0 fragmento $F(a b)_{2}$, (Figura $8 c-$ poço 4$)$.

Figura 8 - Avaliação da pureza do fragmento Fab anti-digoxina presente no sobrenadante da cultura de $E$. coli pela cromatografia em resina de afinidade Proteína G.

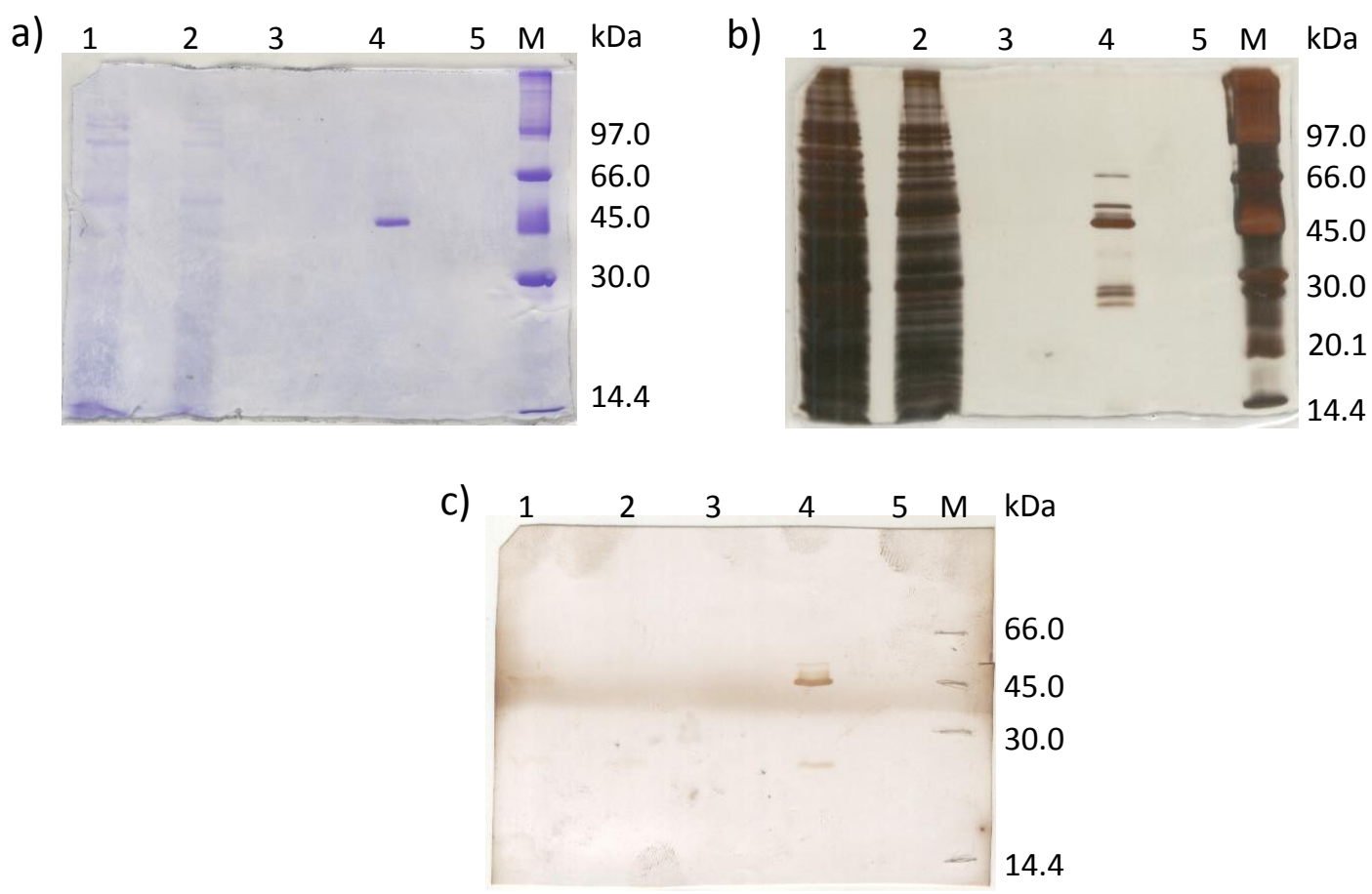

SDS-PAGE (12\%) em 3 géis onde a) coloração por Coomassie, b) coloração por prata e c) Western blotting realizado com 0 anticorpo anti-lgG de camundongo específico para fragmento $F\left(a b^{\prime}\right)_{2}$ conjugado com peroxidase e detecção com o DAB. Foram aplicados $20 \mu \mathrm{L} /$ poço. Poços: 1sobrenadante do cultivo bacteriano; 2- fração não ligada; 3- lavagem; 4- eluato concentrado 21 vezes; 5- enxágue e $\mathrm{M}$ - marcador de baixo peso molecular.

Visto a possibilidade de uso desta metodologia para a purificação dos fragmentos Fab do clone 10, procedeu-se à expressão dos outros clones para os testes de purificação. Os fragmentos Fab dos 4 clones foram quantificados por 
ELISA (método 1) e o grau de pureza verificado por SDS-PAGE a 12\%. Os fragmentos Fab foram analisados nos géis na forma não-reduzida e reduzida com adição de $\beta$-mercaptoetanol. No primeiro gel foram aplicados $2,5 \mu \mathrm{g}$ de fragmento Fab por poço e corado com Coomassie, no outro gel, foram aplicados 0,6 $\mu \mathrm{g}$ de fragmento Fab por poço e corados por prata (Figura 9). Observam-se diferenças nos níveis de pureza das amostras na forma não reduzida, sendo o clone 10 o que apresentou o maior nível de pureza. Quando avaliados na forma reduzida não são observadas diferenças, indicando uma possível agregação ou modificação estrutural dos fragmentos Fab na forma não reduzida.

Figura 9 - SDS-PAGE (12\%) para avaliação da pureza dos fragmentos Fab antidigoxina expressos pelos 4 clones purificados.
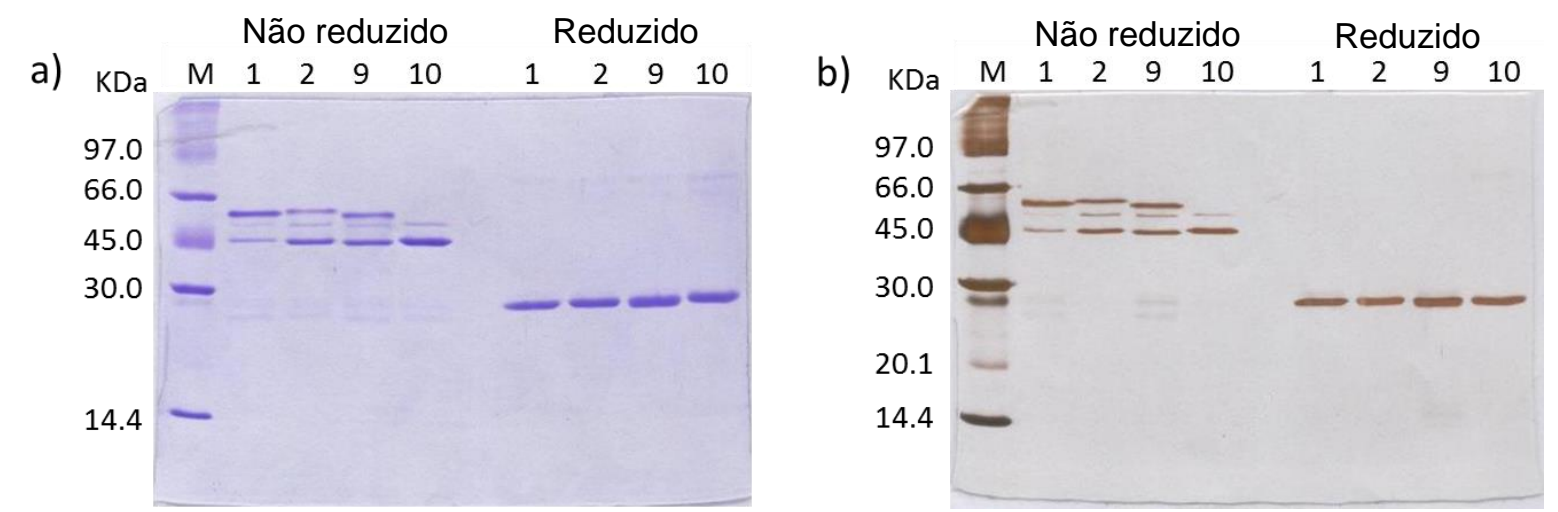

a) gel corado por Coomassie com 2,5 $\mu$ g de amostra por poço e b) gel corado por prata com 0,6 $\mu \mathrm{g}$ de amostra por poço.

$\mathrm{M}$ - marcador de baixo peso molecular.

Os rendimentos dos fragmentos Fab anti-digoxina dos 4 clones foram avaliados através da concentração dos fragmentos, pelo método 1 de ELISA, no sobrenadante do cultivo bacteriano antes e após a purificação. O balanço de massa e a porcentagem de recuperação do produto após a etapa de purificação foram calculados em função dos volumes (Tabela 4). O maior nível de expressão do fragmento Fab anti-digoxina no sobrenadante do cultivo foi obtido pelo clone 2 $(3,52 \mu \mathrm{g} / \mathrm{mL})$. O maior rendimento de purificação foi verificado pelo clone $10(44 \%)$ seguido pelos clones $2(29 \%), 9(23 \%)$ e $1(21 \%)$. 
Tabela 4 - Balanço de massa dos fragmentos Fab anti-digoxina expressos pelos 4 clones, pré e pós purificação por cromatografia em resina de afinidade proteína G.

\begin{tabular}{lccccccc}
\hline & \multicolumn{3}{c}{ Pré-purificação } & \multicolumn{3}{c}{ Pós-purificação } & Rendimento \\
& $\begin{array}{c}\text { Concentração } \\
\mu \mathrm{g} / \mathrm{mL}\end{array}$ & $\begin{array}{c}\text { Volume } \\
\mathrm{mL}\end{array}$ & $\begin{array}{c}\text { Total } \\
\mu \mathrm{g}\end{array}$ & $\begin{array}{c}\text { Concentração } \\
\mu \mathrm{g} / \mathrm{mL}\end{array}$ & $\begin{array}{c}\text { Volume } \\
\mathrm{mL}\end{array}$ & $\begin{array}{c}\text { Total } \\
\mu \mathrm{g}\end{array}$ & $\begin{array}{c}\text { Renificação } \\
\%\end{array}$ \\
\hline Clone 1 & 0,96 & 620 & 595,2 & 255,3 & 0,5 & 127,7 & 21 \\
Clone 2 & 3,52 & 600 & 2112,0 & 381,9 & 1,6 & 611 & 29 \\
Clone 9 & 0,58 & 420 & 243,6 & 149,3 & 0,38 & 56,75 & 23 \\
Clone 10 & 1,51 & 350 & 528,5 & 178,3 & 1,3 & 231,8 & 44 \\
\hline
\end{tabular}

\subsection{Obtenção de fragmentos Fab do espaço periplasmático}

A obtenção dos fragmentos Fab do espaço periplasmático dos 4 clones foi realizada conforme descrito no item 3.8.2.3, a escolha deste protocolo de lise foi motivada pela obtenção dos fragmentos Fab em um menor volume, o que facilita a purificação. Este ensaio foi realizado para verificar o nível de pureza obtido pelos fragmentos Fab presentes neste compartimento após o processo de purificação e a possibilidade de uso destes materiais aumentando o rendimento dos fragmentos Fab. Pela análise do gel de SDS-PAGE (Figura 10) observa-se uma pureza inferior das amostras dos fragmentos Fab obtidos pela lise do espaço periplasmático, quando comparados com os produtos obtidos no sobrenadante. Neste mesmo ensaio foi verificado o nível de pureza do fragmento Fab policlonal anti-digoxina comercial DigiFab ${ }^{\circledR}$.

Figura 10 - SDS-PAGE (12\%) corado por prata dos fragmentos Fab anti-digoxina purificados do sobrenadante e pela lise do periplasma.

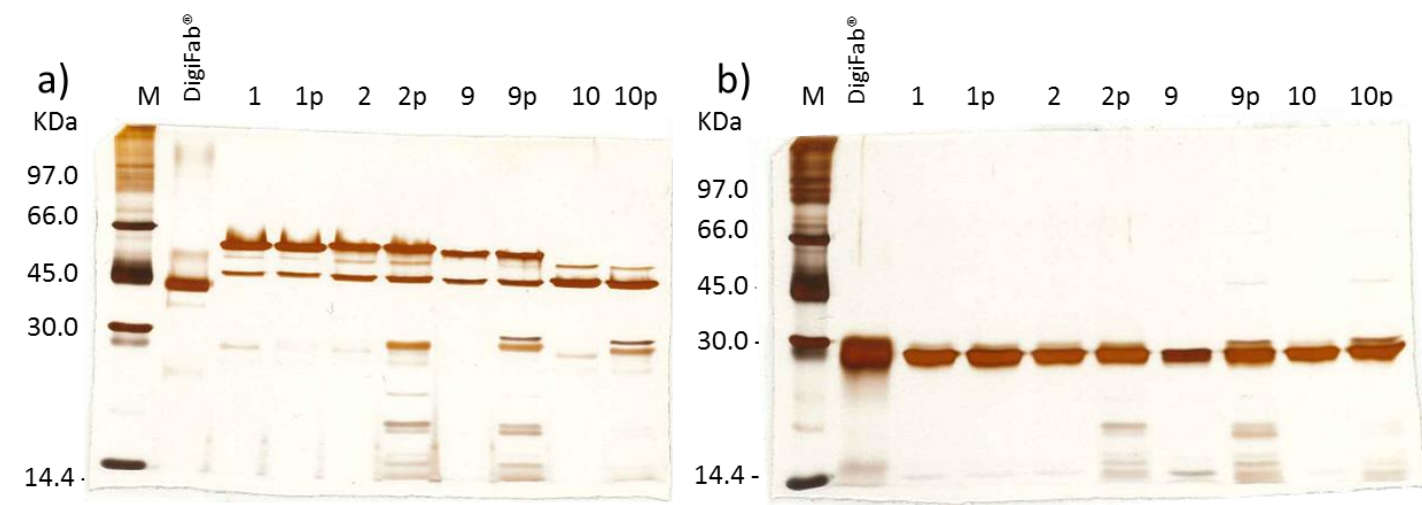

a) amostras não reduzidas; $b$ ) amostras reduzidas. $p=$ periplasma.

Foram aplicados a cada poço $0,6 \mu \mathrm{g}$ de proteína total. 
Os fragmentos Fab eluídos da cromatografia em proteína $G$ foram utilizados para os ensaios de caracterização, apresentando características semelhantes entre si tanto nos ensaios de ligação ao conjugado Dig-BSA, quanto nos ensaios de inibição da ligação à digoxina e aos análogos digoxigenina, digitoxina e ouabaína (dados não mostrados).

\subsection{Aprimoramento das estratégias cromatográficas}

Ainda que a cromatografia em proteína $G$ tenha resultado em purificação específica do fragmento Fab, as amostras não reduzidas (Figuras 8 e 9) contém fração de $25 \mathrm{kDa}$ (apenas a cadeia pesada) ou formatos com maior massa (agregados). Para obter a purificação completa dos fragmentos expressos pelos clones anti-digoxina, foi necessária incluir uma segunda etapa. Primeiramente foi analisado o comportamento de uma etapa cromatográfica posterior à cromatografia por proteína G. A escolha de uma segunda resina teve como base o resultado de ponto isoelétrico apresentado pelos fragmentos semi-purificados (dados não mostrados). A resina de troca catiônica - S Sepharose FF - foi testada em 2 estratégias diferentes na segunda etapa da purificação. Uma terceira estratégia consistiu em usar esta resina como a primeira etapa de purificação.

Para esses testes, o fragmento Fab do clone 2 (maior rendimento de expressão) foi expresso e o sobrenadante da cultura separado em 3 alíquotas contendo aproximadamente $800 \mathrm{~mL}$ de sobrenadante em cada uma.

$\mathrm{Na}$ primeira estratégia avaliada, nomeada de estratégia 1 , foi utilizado 0 ensaio cromatográfico em resina de proteína $\mathrm{G}$, com a abordagem cromatográfica empregada anteriormente na purificação dos sobrenadantes (item 3.9.3.1.1), composta pelo tratamento da amostra com a diafiltração com PBS e concentração por filtração tangencial, equilíbrio e lavagem da resina com a solução Tris $50 \mathrm{mM}$, $\mathrm{NaCl} 150$ mM, pH 7,0 e eluição com o tampão acetato de sódio 200 mM pH 3,0. Neste ensaio não foi realizada a etapa de neutralização do $\mathrm{pH}$ do eluato. $\mathrm{O}$ eluato obtido seguiu para a purificação em resina $S$ Sepharose Hitrap $1 \mathrm{~mL}$, conforme item 3.9.3.2.1. Para o equilíbrio e lavagem da resina foi utilizada a solução acetato de sódio $50 \mathrm{mM}$ pH 5,0 e eluição com gradiente crescente de $\mathrm{NaCl}$. O nível de pureza foi verificado por SDS-PAGE (12\%), o eluato proveniente da primeira etapa de cromatografia (proteína G) apresentou um componente de massa molecular de 
aproximadamente $50 \mathrm{kDa}$, correspondendo ao fragmento Fab anti-digoxina (Figura 11 poço 6). Entretanto, ao concentrar o eluato para seguir para a segunda etapa de cromatografia, verificou-se a presença de componentes de massa molecular menor (Figura 11 poço 7). Não foram observados fragmentos Fab na segunda etapa cromatográfica - S Sepharose (Figura 11 poços 8 a 10).

Figura 11 - SDS PAGE (12\%) - Corado por prata. Estratégia 1 - Cromatografia em resina de proteína $\mathrm{G}$ seguida pela cromatografia de troca catiônica.

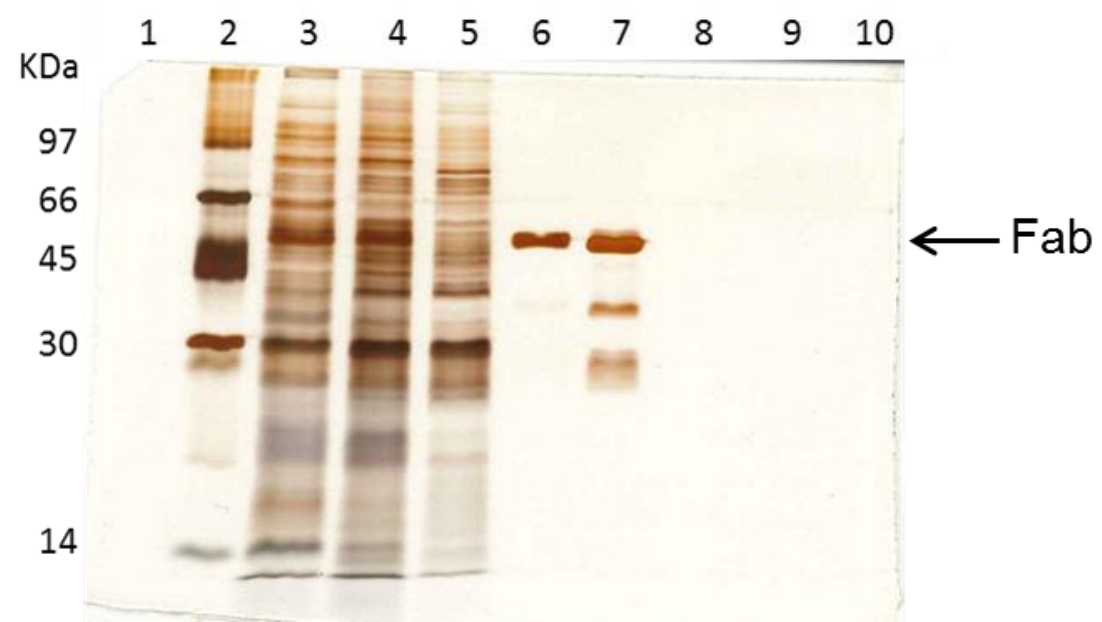

Poços 1 - vazio; 2 - Marcador peso molecular; 3 - sobrenadante cultura do Clone 2; 4 - sobrenadante tratado pré-coluna - proteína G; 5 - fração não ligada - proteína G; 6 - eluato - proteína G; 7 - eluato concentrado - proteína G pré-coluna S Sepharose; 8 - fração não ligada - S Sepharose; 9 - eluato fr. 1 - S Sepharose e 10 - eluato fr. 2 - S Sepharose.

Com a quantificação dos fragmentos Fab pelo ensaio de ELISA método 1, os rendimentos obtidos nesta estratégia cromatográfica foram avaliados (estratégia 1). O cálculo do balanço de massa e da porcentagem de recuperação do produto foi realizado em função dos volumes (Tabela 5). Verificou-se a baixa recuperação do fragmento Fab (42\%) pela etapa de concentração e diafiltração do sobrenadante do cultivo (tratamento da amostra). Na primeira etapa cromatográfica com o uso da resina de proteína $\mathrm{G}$, foram recuperados $11 \%$ do fragmento Fab. Na etapa seguinte (cromatografia em resina S Sepharose) não foram detectados fragmentos Fab no ensaio de quantificação. 
Tabela 5 - Rendimento obtido pela estratégia 1.

\begin{tabular}{lccccc}
\hline \multirow{2}{*}{ Identificação } & \multicolumn{2}{c}{ Concentração } & Volume & Total & \multicolumn{2}{c}{ Rendimento (\%) } \\
& $\boldsymbol{\mu} \mathbf{g} / \mathbf{m L}$ & $\mathbf{m L}$ & $\boldsymbol{\mu g}$ & Etapa & Geral \\
\hline Sobrenadante Cultura & 2,0 & 790 & 1611 & 100 & 100 \\
Tratamento pré-coluna & 2,2 & 300 & 672 & 42 & 42 \\
Proteína G & 101 & 1,8 & 182 & 27 & 11 \\
S Sepharose & 0,0 & 0,11 & 0 & 0 & 0 \\
\hline
\end{tabular}

A seguir, foi feita a avaliação da segunda metodologia cromatográfica (estratégia 2), que difere da estratégia 1 apenas nas soluções utilizadas na cromatografia em resina de proteína $G$ (item 3.9.3.1.2). Para o equilíbrio e lavagem da resina utilizou-se a solução glicina $1,5 \mathrm{M}, \mathrm{NaCl} 3 \mathrm{M}, \mathrm{pH}$ 9,0; para a eluição foram usadas as soluções citrato de sódio $50 \mathrm{mM}, \mathrm{NaCl} 150 \mathrm{mM}, \mathrm{pH}$ 6,0 e citrato de sódio $50 \mathrm{mM}, \mathrm{NaCl} 150 \mathrm{mM}, \mathrm{pH} \mathrm{3,0}$, aplicadas sequencialmente na coluna. O material obtido com o eluato $\mathrm{pH} 6,0$, foi tratado e aplicado na segunda etapa cromatográfica em resina $S$ Sepharose Hitrap $1 \mathrm{~mL}$, item 3.9.3.2.1 (equilíbrio e lavagem da resina com a solução acetato de sódio 50 mM pH 5,0 e eluição com gradiente crescente de $\mathrm{NaCl}$ ). Avaliando o nível de pureza obtido em gel de SDSPAGE a 12\%, verificou-se a existência de impurezas nos eluatos pH 6,0 e 3,0, (Figura 12, poços 2 e 4 respectivamente). $\mathrm{O}$ eluato $\mathrm{pH}$ 6,0 concentrado e tratado (pré-coluna S Sepharose), permitiu uma melhor visualização das impurezas existentes (Figura 12, poço 6). Não foram verificados fragmentos Fab nos eluatos obtidos pelo uso da resina catiônica, observou-se apenas traços na fração não adsorvida e com presença de impurezas (Figura 12, poço 7). 
Figura 12 - SDS PAGE (12\%) - Corado por prata. Estratégia 2 - Cromatografia em resina de proteína $\mathrm{G}$ seguida pela cromatografia de troca catiônica.

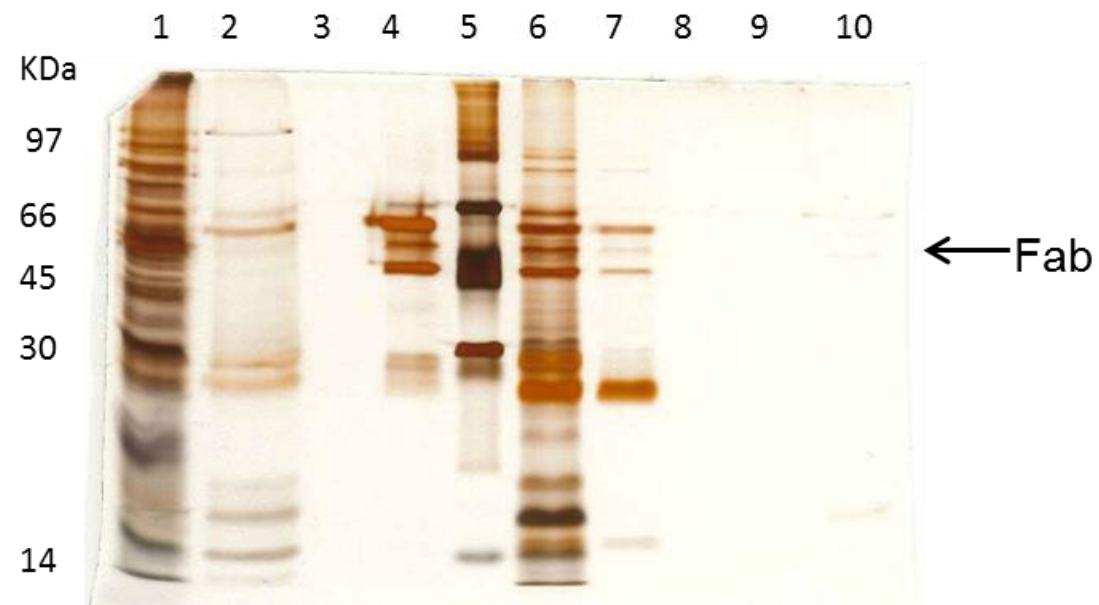

Poços 1 - sobrenadante da cultura Clone 2 tratado pré-coluna proteína G; 2 - eluato pH 6,0 - coluna proteína G; 3 - eluato $\mathrm{pH} 3,0$ fração 1 concentrado - coluna proteína G; 4 - eluato $\mathrm{pH}$ 3,0 fração 2 concentrado - proteína G; 5 - marcador de peso molecular; 6 - eluato pH 6,0 concentrado e tratado pré-coluna S Sepharose; 7 - fração não ligada - S Sepharose; 8 - eluato fração 1 concentrado - $S$ Sepharose; 9 - eluato fação 2 concentrado - S Sepharose e 10 - eluato fração 3 - S Sepharose.

O balanço de massa e a porcentagem de recuperação do produto foram calculados (quantificação por ELISA método 1). Apesar de resultar em maior rendimento na etapa de tratamento pré-coluna do que o observado na estratégia 1 ( $70 \%$ ante $42 \%$ da estratégia 1 ), o rendimento na etapa de captura (Proteína G) foi menor, sendo 2,3\% para o eluato $\mathrm{pH} 6.0$ e de $0,6 \%$ para o eluato $\mathrm{pH} \mathrm{3,0} \mathrm{(Tabela} \mathrm{6).}$ Semelhante ao observado na estratégia 1, não foram detectados fragmentos Fab na segunda etapa cromatográfica (resina S Sepharose).

Tabela 6 - Rendimento obtido pela estratégia 2.

\begin{tabular}{lccccc}
\hline \multicolumn{1}{c}{ Identificação } & $\begin{array}{c}\text { Concentração } \\
\mu \mathrm{g} / \mathrm{mL}\end{array}$ & $\begin{array}{c}\text { Volume } \\
\mathrm{mL}\end{array}$ & $\begin{array}{c}\text { Total } \\
\mu \mathrm{g}\end{array}$ & \multicolumn{2}{c}{ Recuperação (\%) } \\
& 2,0 & 780 & 1591,2 & 100 & 100 \\
\hline Sobrenadante Cultura & 3,6 & 310 & 1116,0 & 70 & 70 \\
Tratamento pré-coluna & 16,9 & 2,20 & 37,2 & 3,3 & 2,3 \\
Proteína G - Eluato $\mathrm{pH}$ 6,0 & 40,6 & 0,25 & 10,2 & 0,9 & 0,6 \\
Proteína G - Eluato $\mathrm{pH} 3,0$ & 0,0 & 0 & 0,0 & 0,0 & 0,0 \\
\hline S Sepharose & & &
\end{tabular}

Continuando a avaliação das diferentes estratégias de purificação, utilizou-se a resina $S$ Sepharose em uma primeira etapa cromatográfica (estratégia 3). A metodologia aplicada foi similar a utilizada nas estratégias 1 e 2 (item 3.9.3.2.1), sendo modificada pela aplicação do sobrenadante da cultura tratado à resina de 
troca catiônica. O SDS-PAGE a 12\% (Figura 13) mostrou que as frações correspondentes aos eluatos (Figura 13 poços 3 e 4) apresentaram impurezas compreendendo toda a faixa de massa molecular analisada (14 a $97 \mathrm{kDa}$ ) e em maior quantidade quando comparada às estratégias 1 e 2. Para a verificação das estratégias abordadas, foram aplicados ao gel de SDS-PAGE o fragmento policlonal anti-digoxina comercial e também o fragmento Fab lgG de camundongo comercial (Figura 13 poços 8 e 10, respectivamente).

Figura 13 - SDS PAGE (12\%) - Corado por prata. Estratégia 3 - Cromatografia de troca catiônica.

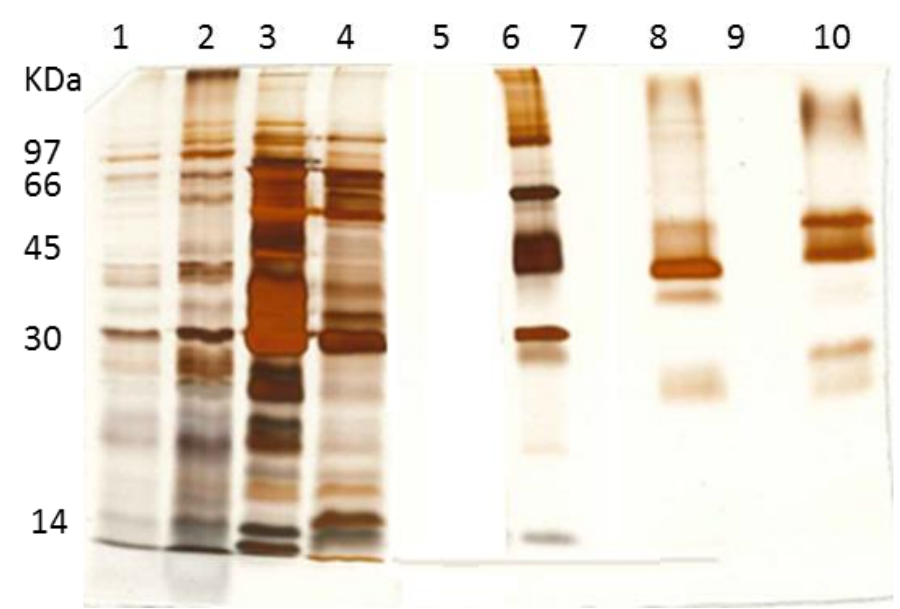

Poços 1 - sobrenadante da cultura Clone 2 tratado pré-coluna catiônica; 2 - fração não ligada; 3 eluato fração 1 concentrado 5x; 4 - eluato fração 2 concentrado 4x; 5 - vazio; 6 - marcador de peso molecular; 7 - vazio; 8 - DigiFab ${ }^{\circledR}$ 0,6 $\mu \mathrm{g} ; 9$ - vazio; 10 - ChromPure Mouse IgG Fab fragment 0,6 $\mu \mathrm{g}$.

Com os dados obtidos pelo balanço de massa e pela recuperação do fragmento Fab, verificamos que e estratégia 3 alcançou a taxa de recuperação total na etapa de tratamento pré-coluna (Tabela 7), o que pode sugerir que a utilização da solução de acetato de sódio $50 \mathrm{mM}$ pH 5,0 seja a melhor condição para a diafiltração dos sobrenadantes. Entretanto, o baixo nível de pureza obtido pelo uso da resina de troca catiônica, nas condições avaliadas, em conjunto com a baixa recuperação dos fragmentos Fab, não justificaram a continuação desta estratégia. 
Tabela 7 - Rendimento obtido pela estratégia 3.

\begin{tabular}{lcccccc}
\hline \multirow{2}{*}{ Identificação } & $\begin{array}{c}\text { Concentração } \\
\mu \mathrm{g} / \mathrm{mL}\end{array}$ & $\begin{array}{c}\text { Volume } \\
\mathrm{mL}\end{array}$ & $\begin{array}{c}\text { Total } \\
\mu \mathrm{g}\end{array}$ & \multicolumn{2}{c}{ Recuperação $(\%)$} \\
Etapa & Geral \\
\hline Sobrenadante Cultura & 2,0 & 790 & 1611,6 & 100 & 100 \\
Tratamento pré-coluna & 5,9 & 280 & 1646,4 & $102^{*}$ & $102^{*}$ \\
S Sepharose fração 1 & 155,3 & 1,00 & 155,3 & 9,4 & 10 \\
S Sepharose fração 2 & 0,7 & 6,50 & 4,3 & 0,3 & 0 \\
\hline
\end{tabular}

* Variações experimentais no ensaio de ELISA pode justificar a taxa calculada superior a $100 \%$.

Das três estratégias avaliadas, a que apresentou melhor capacidade de purificação foi a estratégia 1, entretanto apresentou a menor taxa de recuperação dos fragmentos Fab durante o tratamento do sobrenadante da cultura. Outro dado obtido pela estratégia 1, foi a presença de um único componente de massa molecular correspondente ao fragmento Fab, o que sugere que o fragmento possa sofrer alteração estrutural durante a etapa de neutralização do eluato, visto que neste experimento não foi realizada a neutralização em virtude do passo seguinte de cromatografia (S Speharose) necessitar de condições ligeiramente ácidas.

Com os resultados obtidos pela estratégia 1, testou-se o uso desta estratégia sem a etapa de tratamento da amostra, aplicando o sobrenadante do cultivo apenas clarificado (centrifugado e filtrado $0,45 \mu \mathrm{m}$ ) à resina de proteína G. Nesta abordagem os fragmentos Fab anti-digoxina não foram removidos da resina com passagem da solução de eluição (ácido acético $200 \mathrm{mM} \mathrm{pH} \mathrm{3,0).} \mathrm{A} \mathrm{remoção} \mathrm{dos} \mathrm{fragmentos} \mathrm{Fab}$ adsorvidos à resina de proteína $\mathrm{G}$, só seria possível com a passagem da solução de regeneração (ácido acético $1 \mathrm{M} \mathrm{pH}$ 2,5). $\mathrm{Na}$ tentativa de remoção do produto em uma condição menos agressiva do que o uso da solução de regeneração, foram realizados diversos ensaios com modificações na solução para eluição (adição de concentrações fixas e gradientes de $\mathrm{NaCl}$, diminuição do $\mathrm{pH}$ ), porém sem êxito.

Prosseguindo com os ensaios para purificação dos fragmentos Fab, utilizouse a resina de troca aniônica ( $Q$ Sepharose $F F$ ) como primeiro passo cromatográfico (item 3.9.3.3). Nesta abordagem o material de interesse estaria na fração não ligada. Para tanto, o sobrenadante do cultivo bacteriano do clone 10 foi clarificado e adicionado Tween 20 a $0,05 \%$. O pH e a condutividade da amostra inicial foram medidos, obtendo 7,34 e $7,7 \mathrm{mS} / \mathrm{cm}$, respectivamente. Esse material foi aplicado à resina cromatográfica previamente equilibrada em solução de Tris $20 \mathrm{mM} \mathrm{pH} \mathrm{7,0.}$ 
Pelo gel SDS-PAGE a 12\%, verificou-se que apesar da existência de impurezas em todas as amostras provenientes da eluição e das etapas de regeneração (Figura 14, poços 4 a 9), não foi possível atestar a diminuição nos níveis de contaminantes da fração não ligada (Figura 14, poço 3), quando comparada à amostra inicial.

Pelo ensaio de ELISA método 1 foi possível constatar que não houve perda de fragmentos Fab durante este passo cromatográfico, com a obtenção da massa de $718 \mu \mathrm{g}$ no sobrenadante da cultura e $720 \mu \mathrm{g}$ na fração não ligada.

Figura 14 - SDS PAGE (12\%) - Corado por prata. Cromatografia de troca aniônica.

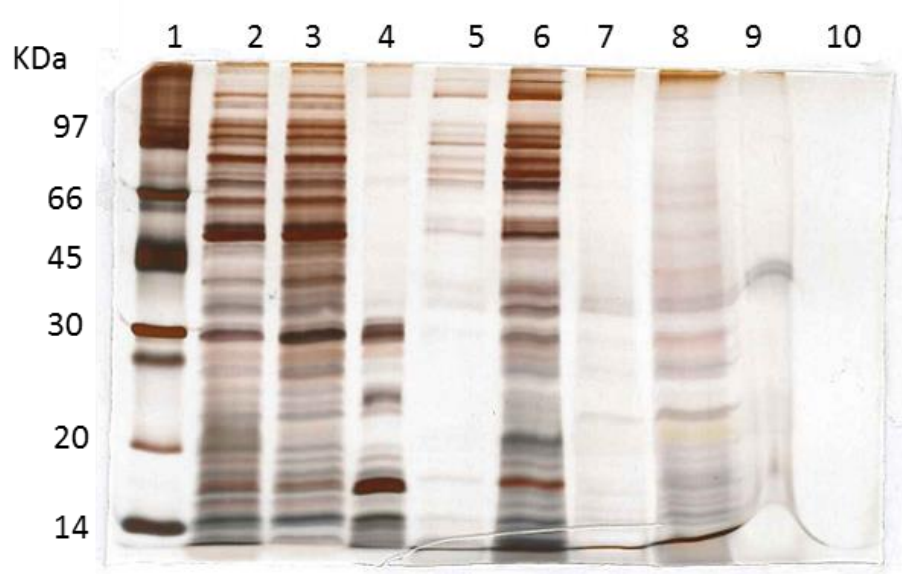

Poços 1 - marcador de peso molecular; 2 - sobrenadante da cultura Clone 10 pré-coluna aniônica (1:10); 3 - fração não ligada (1:10); 4 - eluato fração 1; 5 - eluato fração 2 (1:10); 6 - eluato fração 2; 7 - regeneração $1 ; 8$ - regeneração 1 (1:10); 9 - regeneração 2; 10 - vazio.

A fração não ligada à resina $Q$ Sepharose foi dividida em duas partes, contendo $200 \mathrm{~mL}$ cada, que foram purificadas em resina de proteína $\mathrm{G}$ com duas abordagens diferentes. A uma alíquota procedeu-se à purificação descrita no item 3.9.3.1.1, (equilíbrio e reequilíbrio da resina com Tris $50 \mathrm{mM}, \mathrm{NaCl} 150 \mathrm{mM}, \mathrm{pH}$ 7,0, eluição com acetato de sódio $200 \mathrm{mM}$ pH 3,0 e para a regeneração ácido acético $1 \mathrm{M} \mathrm{pH}$ 2,5). Pela análise do gel de SDS-PAGE a 12\%, observou-se que, semelhante ao verificado com os ensaios de cromatografia em proteína $\mathrm{G}$, quando o material inicial não foi diafiltrado e concentrado, a solução usada para a eluição não foi capaz de remover os fragmentos Fab adsorvidos na coluna (Figura 15, poços $5 \mathrm{e}$ 6). Também neste caso a eluição do fragmento Fab só foi possível com a utilização da solução de regeneração (Figura 15 poço 7). Na tentativa de confirmar se a etapa de neutralização do material purificado foi responsável por alterações estruturais ou 
agregação dos fragmentos Fab, foram analisados em gel de SDS-PAGE a $12 \%$ os materiais pré e pós-neutralização (Figura 15, poços 7 a 9), os quais, apresentaram diferenças nos perfis eletroforéticos, comprovando que esta etapa foi responsável pelas modificações estruturais ou formação de agregados nos fragmentos Fab.

Figura 15 - SDS PAGE (12\%) - Coloração por prata. Cromatografia em resina de afinidade como segunda etapa cromatográfica após troca aniônicaalíquota 1.

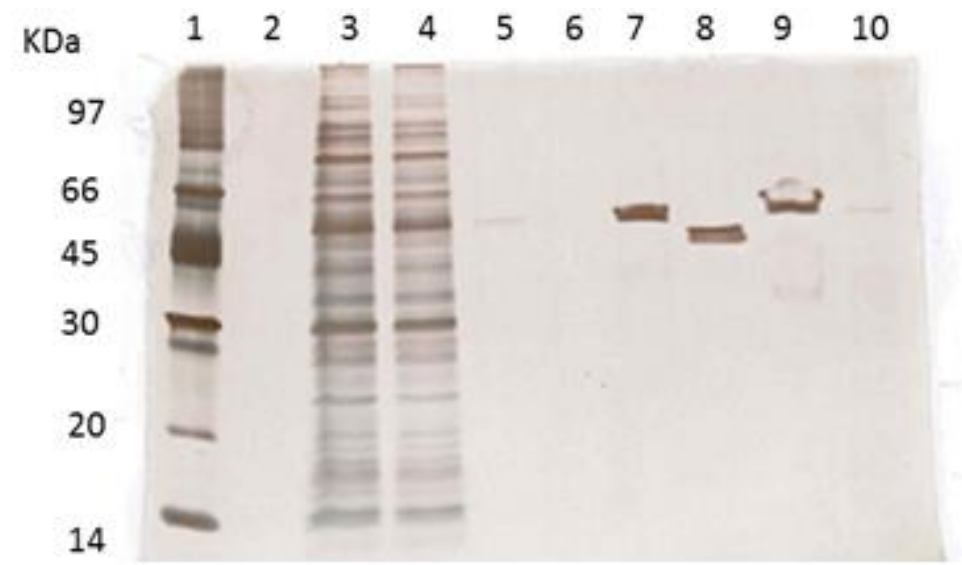

Poços 1 - marcador de peso molecular; 2 - vazio; 3 - fração não ligada da coluna de troca aniônica pré-coluna de proteína $\mathrm{G}(1: 10) ; 4$ - fração não ligada - Proteína $\mathrm{G}(1: 10) ; 5$ - eluato fração $1 ; 6$ eluato fração 2; 7 - regeneração fração 1 pré-neutralização; 8 - regeneração fração 1 neutralizada; 9 - regeneração fração 2 não neutralizada; 10 - enxágue.

A segunda alíquota foi processada de forma semelhante à primeira, com modificação apenas na solução de equilíbrio e reequilíbrio da resina sendo utilizada a solução de glicina $1,5 \mathrm{M}, \mathrm{NaCl} 3,0 \mathrm{M} \mathrm{pH} \mathrm{9,0.} \mathrm{Como} \mathrm{visto} \mathrm{na} \mathrm{primeira} \mathrm{alíquota} \mathrm{a}$ solução de eluição não foi capaz de remover os fragmentos Fab (Figura 16, poços 5 a 7), sendo retirados apenas pela solução de regeneração. O grau de pureza observado com esta abordagem mostrou-se inferior ao obtido pelo processo utilizado na primeira alíquota. Também foram verificadas diferenças entre os fragmentos Fab pré e pós-neutralização (Figura 16, poços 8 e 9, respectivamente). 
Figura 16 - SDS-PAGE (12\%) Coloração por prata. Cromatografia em resina de afinidade como segunda etapa cromatográfica após troca aniônicaalíquota 2.

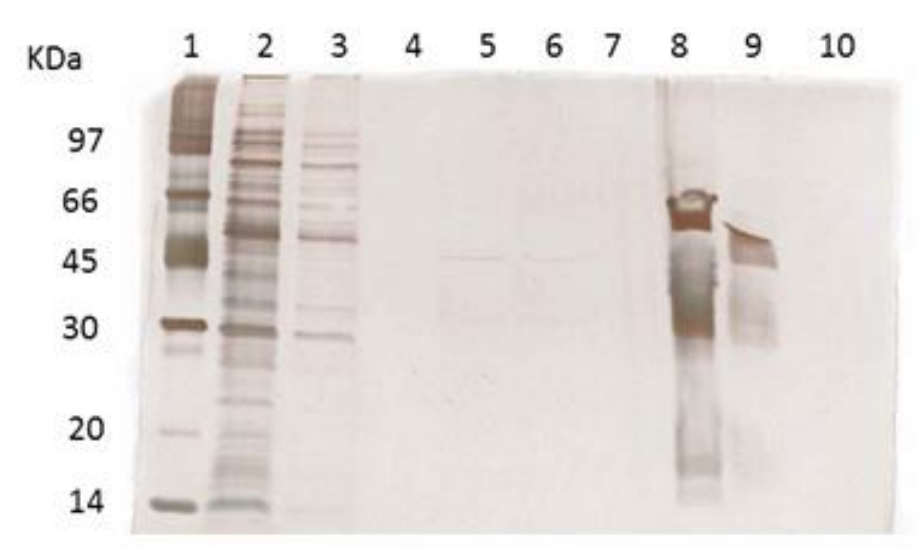

Poços 1 - marcador de peso molecular; 2 - fração não ligada da coluna de troca aniônica pré-coluna de proteína G (1:10); 3 - fração não ligada - Proteína G (1:10); 4 - vazio; 5 - eluato fração 1 préneutralização; 6 - eluato fração 1 neutralizado; 7 - eluato fração $2 ; 8$ - regeneração préneutralização; 9 - regeneração pós-neutralização; 10 - enxágue.

Devido aos resultados cromatográficos obtidos, avaliou-se novamente o uso da resina de troca catiônica $S$ Sepharose com a abordagem descrita no item 3.9.3.2.2, em uma etapa de captura. Para tanto, o sobrenadante da cultura do clone

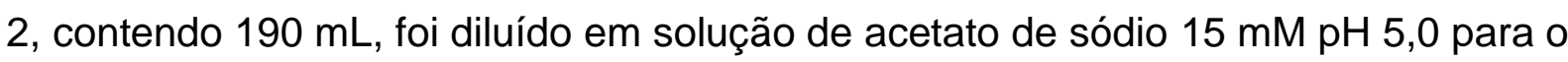
ajuste da condutividade e do $\mathrm{pH}$. A amostra foi aplicada à resina $\mathrm{S}$ Sepharose FF previamente equilibrada com a solução de acetato de sódio $15 \mathrm{mM} \mathrm{pH} \mathrm{5,0.} \mathrm{A} \mathrm{eluição}$ foi realizada com a passagem sequencial das soluções de fosfato de sódio $20 \mathrm{mM}$ $\mathrm{pH} \mathrm{7,0} \mathrm{(eluato} \mathrm{1)} \mathrm{e} \mathrm{da} \mathrm{solução} \mathrm{fosfato} \mathrm{de} \mathrm{sódio} 20 \mathrm{mM}, \mathrm{NaCl}$ 1,5 M pH 7,0 (eluato 2). Neste passo cromatográfico inicial, não foi verificada melhoria no nível pureza nos eluatos utilizados (Figura 17, poços 5 a 10), porém, foi possível concentrar o material e também permitiu a aplicação dos eluatos na resina de proteína $G$ sem a necessidade de tratamento prévio, visto que os materiais obtidos nos eluatos possuem condições próximas às iniciais do processo seguinte. 
Figura 17 - SDS-PAGE (12\%) Corado por prata. Cromatografia em resina de troca catiônica, primeira etapa cromatográfica.

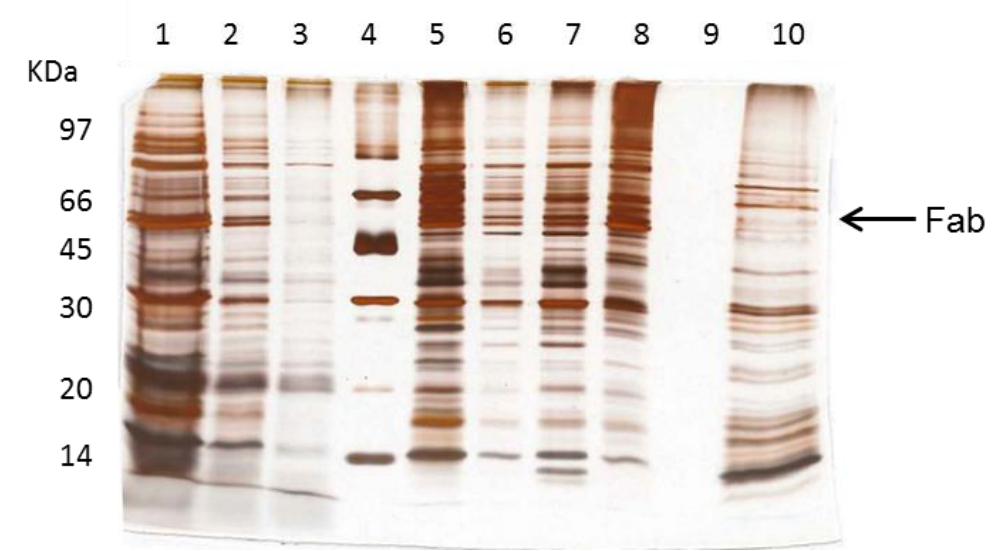

Poços: 1 - sobrenadante clone 2 pré-tratamento; 2 - sobrenadante clone 2 pós-tratamento; 3 - fração não ligada; 4 - marcador de peso molecular; 5 - eluato 1 fração $1 ; 6$ - eluato 1 fração 2; 7 - eluato 1 fração $3 ; 8$ - eluato 2 fração 1; 9 - vazio; 10 - eluato 2 fração 2 .

Prosseguindo com o processo cromatográfico, foram realizadas duas purificações em resina de proteína $G$, sendo um processo para a mistura das frações do eluato 1 e um para a mistura das frações do eluato 2, obtidos na etapa de captura.

As frações 1 a 3 do eluato 1 obtido pela passagem da solução de fosfato de sódio $20 \mathrm{mM} \mathrm{pH} \mathrm{7,0} \mathrm{(eluição} \mathrm{1),} \mathrm{na} \mathrm{coluna} S$ Sepharose, foram misturadas e aplicadas à resina de proteína $\mathrm{G}$ e realizada a cromatografia conforme descrito no item 3.9.3.1.3 (equilíbrio e reequilíbrio com solução de fosfato de sódio $20 \mathrm{mM}$ pH 7,0 e eluição com solução de glicina 100 mM pH 2,7). Na análise do gel de SDSPAGE não foram visualizados fragmentos Fab na eluição e na regeneração (Figura 18 , poços 6 e 8 , respectivamente). 
Figura 18 - SDS-PAGE (12\%) Cromatografia de afinidade - segunda etapa cromatográfica -1 .

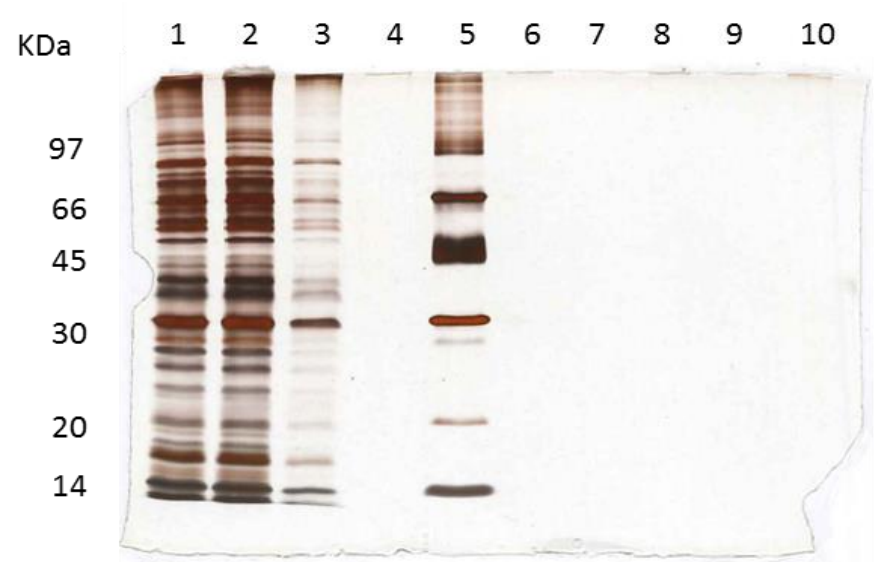

Poços: 1 - eluato 1 frações 1 a 3 obtidos na cromatografia inicial (S Sepharose) pré coluna de proteína G; 2 - fração não ligada; 3 - lavagem/reequilíbrio da resina; 4 - vazio; 5 - marcador de peso molecular; 6 - eluato; 7 - vazio; 8 - regeneração; 9 - vazio; 10 - enxágue.

A mistura das frações 1 e 2 do eluato 2 obtidas com a passagem da solução de fosfato de sódio $20 \mathrm{mM}, \mathrm{NaCl}$ 1,5 M pH 7,0 (eluição 2), na coluna S Sepharose foi processada em coluna de proteína $G$ (item 3.9.3.1.3). Diferente ao observado na cromatografia das frações obtidas pelo eluato 1 da coluna $S$ Sepharose, o fragmento Fab foi visualizado por SDS-PAGE, nos poços correspondentes à eluição, em duas frações distintas. Na primeira fração foram visualizados fracamente o material de interesse com a presença de impurezas (Figura 19, poço 7) e na segunda fração que correspondente ao segundo pico da eluição, foram obtidos os fragmentos Fab com o grau de pureza desejado (Figura 19, poço 8).

Figura 19 - SDS-PAGE (12\%) Cromatografia de afinidade - segunda etapa cromatográfica -2 .

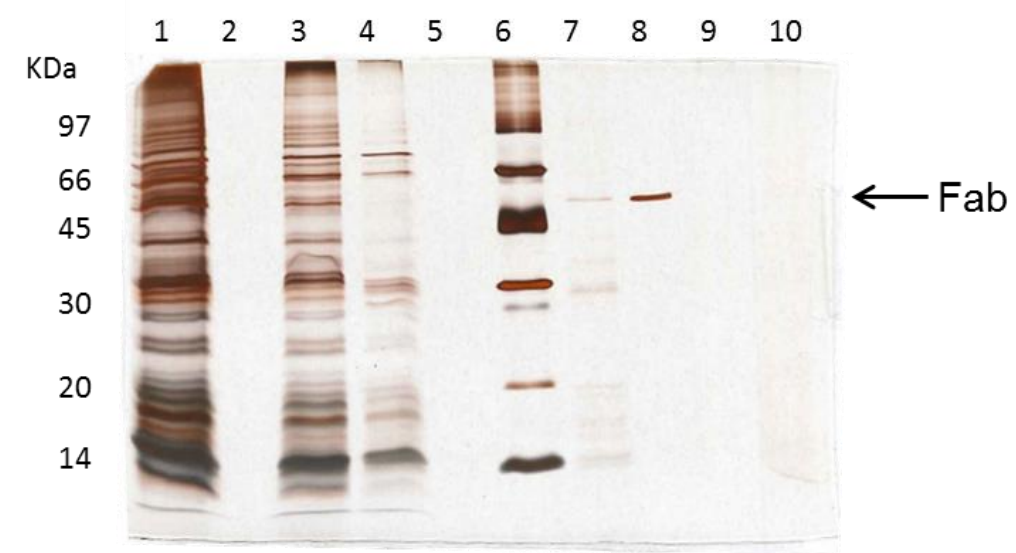

Poços: 1 - eluato 2 frações 1 e 2 obtidos na cromatografia inicial (S Sepharose) pré coluna de proteína G; 2 - vazio; 3 - fração não ligada; 4 - lavagem/reequilíbrio da resina; 5 - vazio; 6 marcador de peso molecular; 7 - eluato fração 1; 8 - eluato fração 2; 9 - regeneração; 10 - enxágue. 
Com os resultados obtidos nessa estratégia (cromatografia em S Sepharose e cromatografia em proteína $G$ ), foi realizada a expressão dos fragmentos Fab dos 4 clones e a utilização desta metodologia para avaliar os padrões cromatográficos.

$\mathrm{Na}$ primeira etapa cromatográfica em resina de troca catiônica, observa-se a existência de picos cromatográficos tanto com a passagem da solução de fosfato de sódio $20 \mathrm{mM} \mathrm{pH} \mathrm{7,0} \mathrm{-} \mathrm{eluição} \mathrm{1,} \mathrm{quanto} \mathrm{pela} \mathrm{passagem} \mathrm{da} \mathrm{mesma} \mathrm{solução}$ contendo $\mathrm{NaCl}$ 1,5 M - eluição 2, em todos os sobrenadantes avaliados (Figura 20). Apesar da existência de picos cromatográficos nos dois eluatos obtidos na cromatografia de troca cationica, os fragmentos Fab dos clones 1 e 10 foram removidos com a solução de eluição 1, enquanto que os dos clones 2 e 9 pela solução de eluição 2. Estas alterações observadas na eluição dos fragmentos Fab podem ter sido motivadas por diferenças na força de interação com a resina catiônica e/ou por possíveis variações entre os pontos isoelétricos dos produtos de cada clone.

Seguindo para a segunda etapa cromatográfica, as frações contendo os fragmentos Fab foram purificadas em resina de proteína $G$ e os cromatogramas estão apresentados na Figura 21. Os eluatos estão ampliados para permitir a verificação dos picos cromatográficos e a fração contendo os fragmentos Fab, verificada em gel de poliacrilamida a $12 \%$, encontra-se hachurada.

Com a quantificação dos fragmentos Fab dos 4 clones por ELISA, o balanço de massa foi realizado em função dos volumes e a taxa de recuperação calculada (Tabela 8). Os sobrenadantes dos clones 1, 2 e 10 apresentaram a mesma concentração de fragmentos Fab. $O$ clone 9 apresentou a menor concentração de produto no sobrenadante da cultura. A utilização da resina $S$ Sepharose apresentou diminuída taxa de recuperação do fragmento $\mathrm{Fab}$ para todos os clones, especialmente para os clones 1 e 2 obtendo-se $2 \%$ e $5 \%$, respectivamente. A melhor taxa de recuperação total foi alcançada pelo fragmento Fab do clone $10(25 \%)$, os produtos dos clones 2 e 9 apresentaram uma taxa de $2 \%$ e a menor taxa de recuperação total foi obtida pelo clone $1(0,2 \%)$ ( Tabela 8 ). 
Figura 20 - Cromatogramas das purificações dos sobrenadantes dos 4 clones em coluna S Sepharose FF.
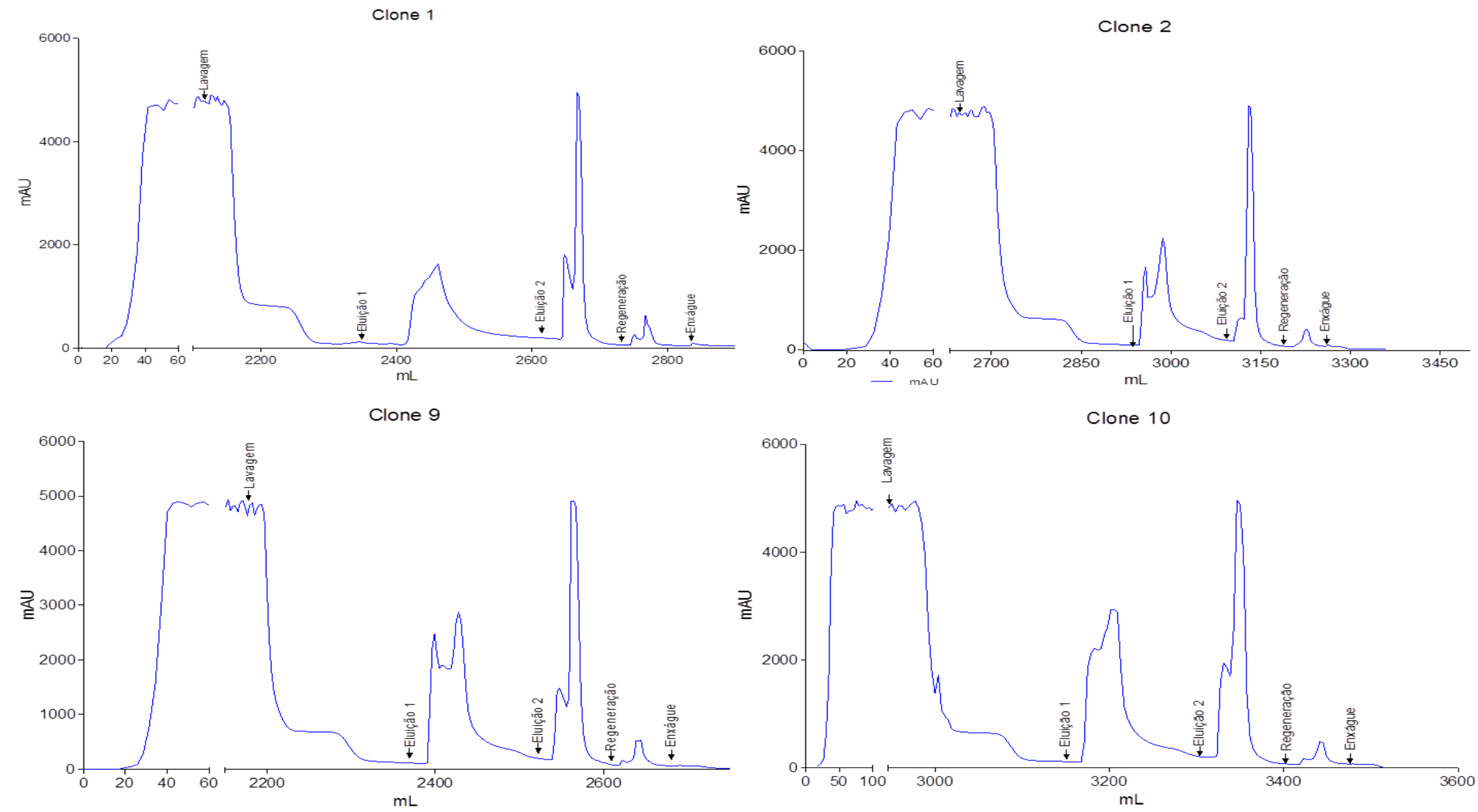

Sobrenadante diluído 4 vezes com acetato de sódio $15 \mathrm{mM} \mathrm{pH} \mathrm{5,0} \mathrm{e} \mathrm{correção} \mathrm{do} \mathrm{pH} \mathrm{para} \mathrm{5,0} \mathrm{e} \mathrm{aplicado} \mathrm{à} \mathrm{coluna} \mathrm{S} \mathrm{Sepharose} \mathrm{FF.} \mathrm{Equilíbrio,} \mathrm{lavagem} \mathrm{e}$ enxágue: acetato de sódio $15 \mathrm{mM} \mathrm{pH} \mathrm{5,0;} \mathrm{Eluição} \mathrm{1:} \mathrm{fosfato} \mathrm{de} \mathrm{sódio} 20 \mathrm{mM} \mathrm{pH} \mathrm{7,0;} \mathrm{Eluição} \mathrm{2:} \mathrm{fosfato} \mathrm{de} \mathrm{sódio} 20 \mathrm{mM}, \mathrm{NaCl} 1,5 \mathrm{M} \mathrm{pH}$ 7,0; Regeneração: $\mathrm{NaOH} 0,1 \mathrm{M}$. 
Figura 21 - Cromatogramas das purificações em resina de proteína G das frações contendo os fragmentos Fab provenientes da cromatografia em coluna S Sepharose.
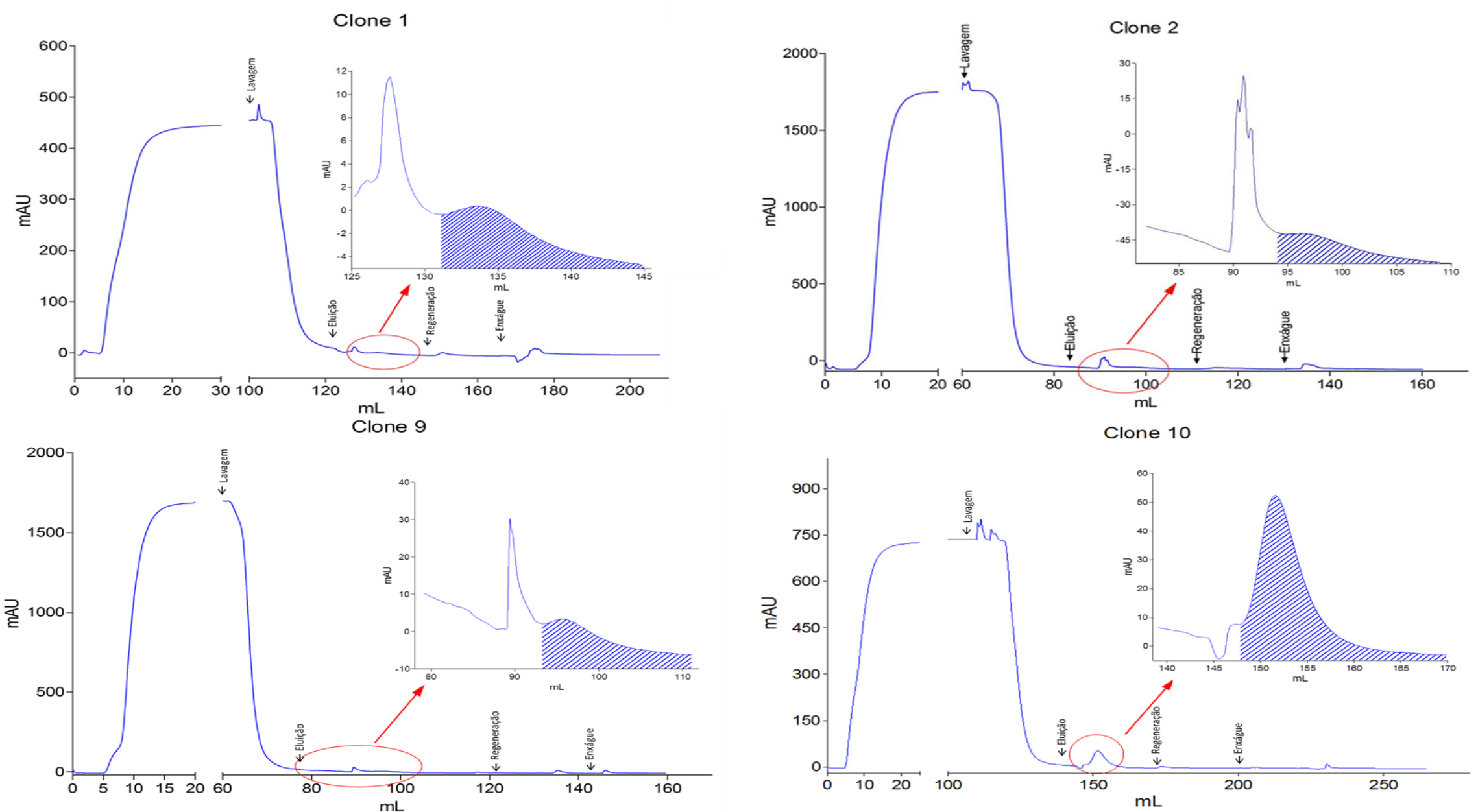

As frações contendo os fragmentos Fab, provenientes da coluna S Sepharose foram aplicadas a coluna Proteína G FF. Equilíbrio, lavagem e enxágue: fosfato de sódio $20 \mathrm{mM} \mathrm{pH} \mathrm{7,0;} \mathrm{Eluição:} \mathrm{glicina} 100 \mathrm{mM} \mathrm{pH} \mathrm{2,7;} \mathrm{Regeneração:} \mathrm{ácido} \mathrm{acético} 1 \mathrm{M}$. Em hachurado está representada a fração da eluição que contém os fragmentos purificados. 
Tabela 8 - Balanço de massa dos fragmentos Fab dos 4 clones.

\begin{tabular}{|c|c|c|c|c|c|c|}
\hline & \multirow{2}{*}{ Identificação } & \multirow{2}{*}{$\begin{array}{c}\text { Concentração } \\
\mu \mathrm{g} / \mathrm{mL}\end{array}$} & \multirow{2}{*}{$\begin{array}{c}\text { Volume } \\
\mathrm{mL}\end{array}$} & \multirow{2}{*}{$\begin{array}{c}\text { Total } \\
\mu \mathrm{g}\end{array}$} & \multicolumn{2}{|c|}{$\begin{array}{c}\text { Recuperação } \\
(\%)\end{array}$} \\
\hline & & & & & Etapa & Geral \\
\hline \multirow{4}{*}{$\begin{array}{l}\frac{\overline{0}}{0} \\
\frac{\Upsilon}{0} \\
\frac{0}{0}\end{array}$} & Sobrenadante Cultura & 1,17 & 580 & 678,6 & 100 & 100 \\
\hline & Tratamento pré-coluna & 0,29 & 2225 & 645,3 & 95 & 95 \\
\hline & S Sepharose pré-coluna Prot. G & 0,13 & 105 & 13,3 & 2 & 2 \\
\hline & Proteína G & 0,15 & 12 & 1,7 & 13 & 0,2 \\
\hline \multirow{4}{*}{$\begin{array}{l}\text { N } \\
\mathbb{1} \\
\stackrel{5}{0} \\
0\end{array}$} & Sobrenadante Cultura & 1,18 & 580 & 684,4 & 100 & 100 \\
\hline & Tratamento pré-coluna & 0,25 & 2350 & 587,5 & 86 & 86 \\
\hline & S Sepharose pré-coluna Prot. G & 0,38 & 71 & 27,0 & 5 & 4 \\
\hline & Proteína G & 1,14 & 13 & 14,8 & 55 & 2 \\
\hline \multirow{4}{*}{$\begin{array}{l}0 \\
\Phi \\
\stackrel{0}{0} \\
0\end{array}$} & Sobrenadante Cultura & 0,42 & 580 & 243,6 & 100 & 100 \\
\hline & Tratamento pré-coluna & 0,10 & 2160 & 216,0 & 89 & 89 \\
\hline & S Sepharose pré-coluna Prot. G & 0,53 & 59 & 31,5 & 15 & 13 \\
\hline & Proteína G & 0,48 & 13 & 6,0 & 19 & 2 \\
\hline \multirow{4}{*}{$\begin{array}{l}\frac{0}{0} \\
\stackrel{0}{0} \\
\frac{0}{0}\end{array}$} & Sobrenadante Cultura & 1,22 & 590 & 719,8 & 100 & 100 \\
\hline & Tratamento pré-coluna & 0,25 & 2386 & 606,0 & 84 & 84 \\
\hline & S Sepharose pré-coluna Prot. G & 1,69 & 137 & 231,5 & 38 & 32 \\
\hline & Proteína G & 12,97 & 14 & 181,6 & 78 & 25 \\
\hline
\end{tabular}

Após a verificação das características de purificação para cada clone, os mesmos foram expressos e purificados para a obtenção de massa para a realização dos ensaios de caracterização. As frações correspondentes aos fragmentos Fab de cada clone foram misturadas e o nível de pureza avaliado por SDS-PAGE a $12 \%$, onde, foram aplicados $0,6 \mu \mathrm{g}$ de proteína total de cada amostra no gel (Figura 22). Os fragmentos Fab dos 4 clones exibiram elevado grau de pureza, não sendo verificadas diferenças entre os clones, apresentando-se como um componente de massa molecular único com cerca de $50 \mathrm{kDa}$.

Com a obtenção dos fragmentos Fab anti-digoxina dos 4 clones com a quantidade de massa e o grau de pureza desejados, deu-se início aos ensaios de caracterização. 
Figura 22 - SDS PAGE (12\%). Pureza dos fragmentos Fab anti-digoxina.

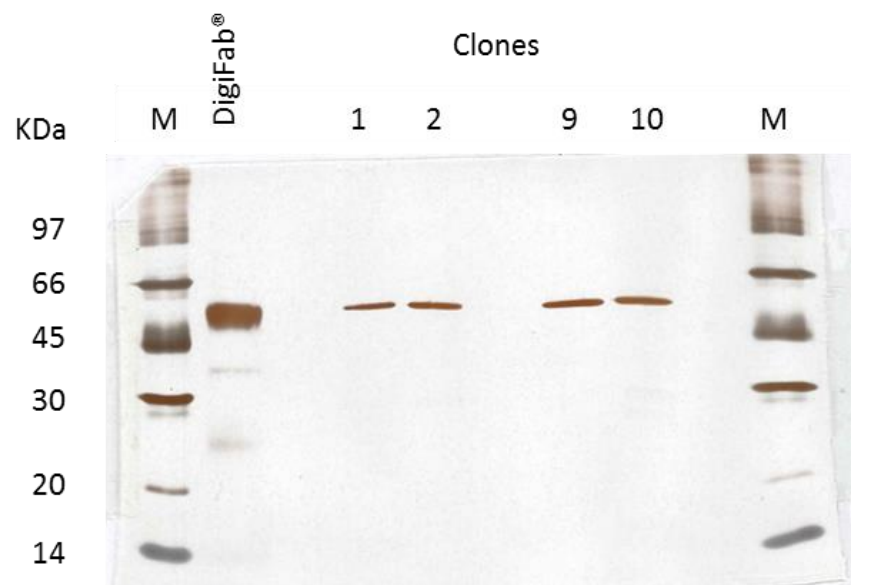

M: marcador de peso molecular

\subsection{Caracterização dos fragmentos Fab anti-digoxina}

\subsubsection{Determinação do ponto isoelétrico dos fragmentos Fab anti-digoxina}

O pl dos fragmentos Fab anti-digoxina dos 4 clones e também do DigiFab ${ }^{\circledR}$ foi verificado pelo ensaio de focalização isoelétrica (IEF) no equipamento Phast System $^{\mathrm{TM}}$ (Figura 23). Pela análise do gel verificou-se um pl alcalino para o DigiFab $^{\circledR}$ com 2 isoformas evidentes, uma de pl 8,65 e outra de pl 9,30. Os fragmentos Fab dos clones 2 e 10 apresentaram perfis isoelétricos mais alcalinos, enquanto que os obtidos pelos clones 1 e 9 foram mais ácidos.

Os fragmentos Fab dos clones 2, 9 e 10 compreendem a faixa de pl entre 6,85 a 8,1 , e o clone 1 a faixa de 5,85 a 7,35. Nota-se também diferenças nas quantidades de isoformas, com a existência de 5 para os fragmentos Fab do clone 1 , 4 para os clones 9 e 10 e a presença de 3 isoformas para o clone 2 . 
Figura 23 - Focalização isoelétrica em gel de poliacrilamida pH 3 a 10. Corado por prata.

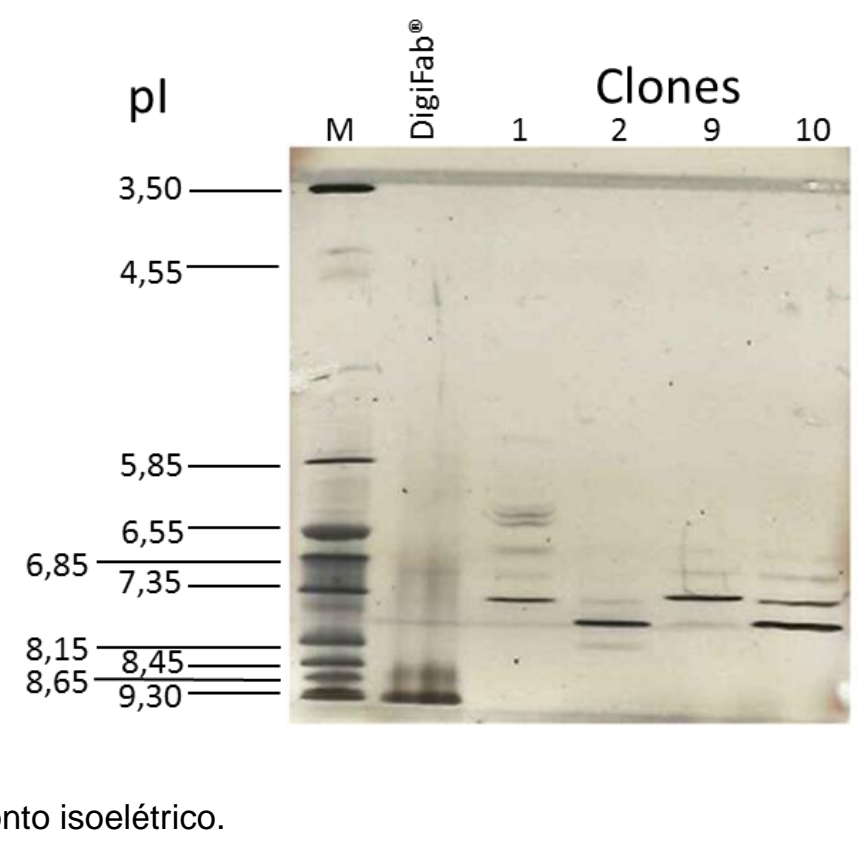

\subsubsection{Caracterização da afinidade e especificidade do fragmento Fab anti- digoxina}

A concentração dos fragmentos Fab dos 4 clones utilizada nos ensaios de caracterização foi determinada pelo ensaio de ressonância plasmônica de superfície (SPR) realizado no equipamento Biacore T200 (item 3.10.3).

Para avaliar a ligação entre os fragmentos Fab anti-digoxina purificados dos 4 clones e o DigiFab ${ }^{\circledR}$ com o conjugado Dig-BSA foi realizado o ensaio de Western blotting. Para tanto, a Dig-BSA foi aplicada em géis de SDS-PAGE a 12\% nas concentrações de 0,250; 0,125 e 0,063 mg/mL, além de BSA na concentração de $0,250 \mathrm{mg} / \mathrm{mL}$ como controle negativo. Após a corrida eletroforética, os géis foram transferidos para membranas de PVDF. O resultado, apresentado na Figura 24, mostra, conforme esperado, que os fragmentos Fab anti-digoxina purificados dos 4 clones e o DigiFab ${ }^{\circledR}$ reconhecem especificamente a porção digoxina do conjugado, uma vez que não houve ligação com a BSA presente no composto Dig-BSA. 
Figura 24 - Avaliação da ligação entre os fragmentos Fab anti-digoxina à Dig-BSA e BSA.

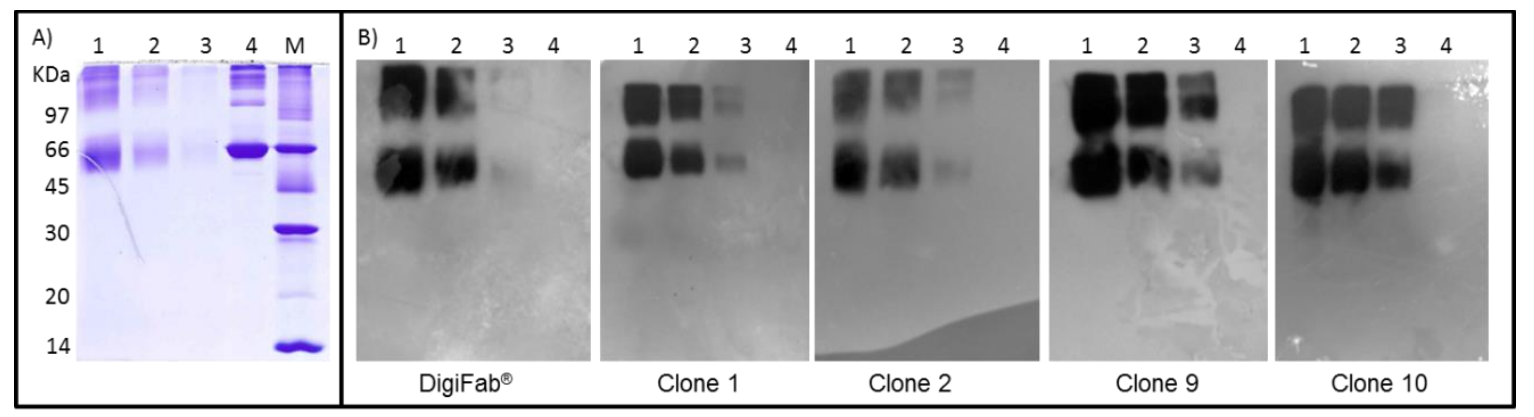

A) Eletroforese em gel de poliacrilamida 12\%, corado por Coomassie. B) Western blotting. As membranas foram incubadas com os fragmentos Fab anti-digoxina dos clones e $\operatorname{DigiFab}^{\circledR}(0,25$ $\mu \mathrm{g} / \mathrm{mL}$ ), seguida pela incubação da membrana com o anticorpo anti-lgG de camundongo específico para fragmento $F\left(a b^{\prime}\right)_{2}$ conjugado com peroxidase para os fragmentos Fab dos 4 clones e com 0 anticorpo anti-IgG de cabra conjugado com peroxidase para o DigiFab ${ }^{\circledR}$. A detecção foi realizada com ECL. Poços M - marcador de baixo peso molecular; 1 - Dig-BSA 0,250 mg/mL; 2- Dig-BSA 0,125 $\mathrm{mg} / \mathrm{mL}$; 3- Dig-BSA 0,063 mg/mL; 4- BSA 0,250 mg/mL.

O perfil de ligação dos fragmentos Fab anti-digoxina à Dig-BSA e BSA foi analisado por ELISA método 2 (Figura 25). Verificou-se a ligação específica entre os fragmentos $\mathrm{Fab}$ dos clones à Dig-BSA, não havendo ligação com a BSA, confirmando o resultado do Western blotting. O fragmento Fab obtido pelo clone 9 apresentou as maiores medidas de absorbância a $450 \mathrm{~nm}$, enquanto que o do clone 2 , as menores. Os produtos dos clones 1 e 10 tiveram perfis de ligação ao conjugado Dig-BSA semelhantes.

Para avaliar a especificidade de ligação entre os fragmentos Fab anti-digoxina purificados dos 4 clones e 0 DigiFab ${ }^{\circledR}$ com a digoxina e os análogos digitoxina, digoxigenina e ouabaína, foi realizado o ensaio de ELISA de inibição (método 3). O ensaio foi realizado nas mesmas condições para os fragmentos Fab avaliados para permitir a comparação da especificidade de ligação à digoxina e aos análogos avaliados, com modificação apenas no anticorpo conjugado com peroxidase utilizado para $\circ$ DigiFab $^{\circledR}$, em virtude de sua origem ser ovina enquanto que os fragmentos Fab dos 4 clones são de origem murina. 
Figura 25 - ELISA método 2 para avaliar o perfil de ligação entre os fragmentos Fab anti-digoxina à Dig-BSA e BSA.

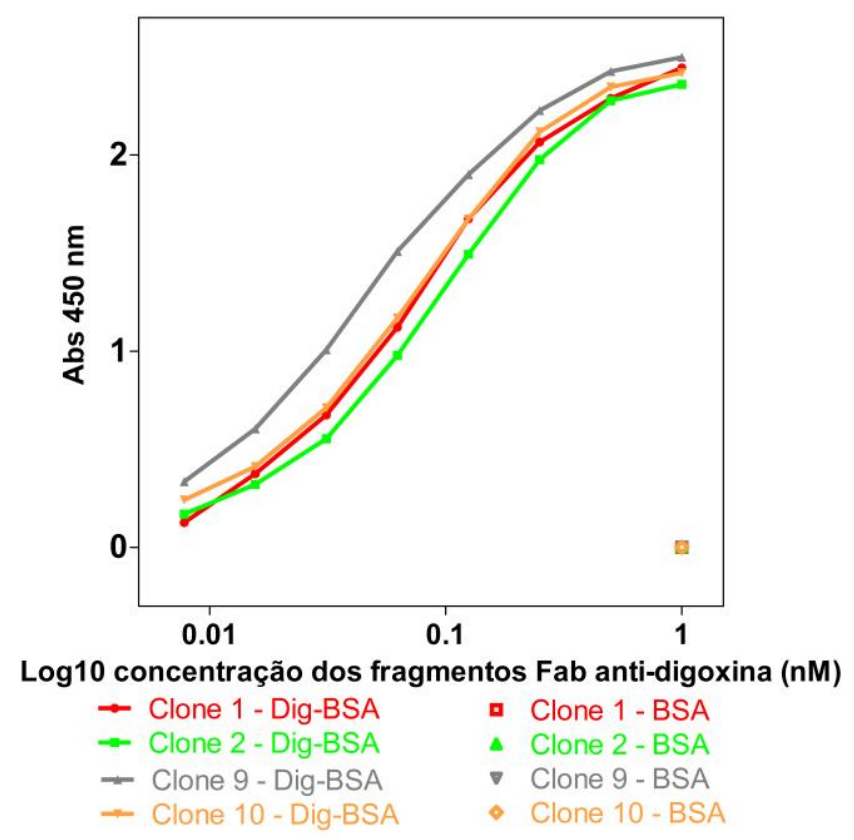

Sensibilização da placa com Dig-BSA ou BSA a $4 \mu \mathrm{g} / \mathrm{mL}$. Os fragmentos Fab foram aplicados na concentração inicial de $1 \mathrm{nM}$ e diluídos serialmente na razão 1:2. Como anticorpo secundário utilizouse $o$ anticorpo anti-lgG de camundongo específico para fragmento $\mathrm{F}\left(\mathrm{ab} \mathrm{b}^{\prime}\right)_{2}$ conjugado com peroxidase.

Com a utilização da digoxina como inibidor entre a ligação dos fragmentos Fab e o conjugado Dig-BSA sensibilizado à placa, foi verificada a formação de complexos dos fragmentos Fab e DigiFab ${ }^{\circledR}$ com cada inibidor, demonstrando a especificidade de ligação à digoxina livre. Na Figura 26 é apresentada a porcentagem de inibição da ligação dos Fabs anti-digoxina e o produto comercial ao conjugado Dig-BSA. A digoxina foi capaz de inibir a ligação entre o DigiFab ${ }^{\circledR}$ e à Dig-BSA com as menores concentrações. Entre os 4 clones, as menores concentrações de digoxina que possibilitaram a inibição foram obtidas pelo fragmento Fab do clone 2. 
Figura 26 - ELISA de inibição da ligação entre os fragmentos Fab anti-digoxina e a Dig-BSA pela digoxina.

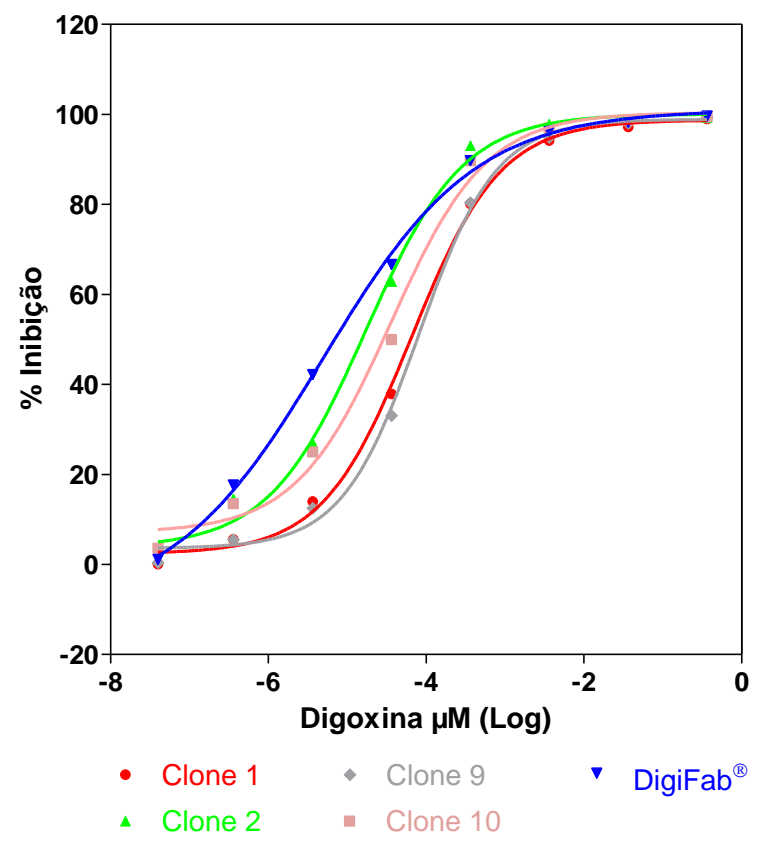

Sensibilização da placa com Dig-BSA a $4 \mu \mathrm{g} / \mathrm{mL}$. Os fragmentos Fab e o DigiFab ${ }^{\circledR}$ foram diluídos para $1 \mathrm{nM}$ em duplicata e misturados a digoxina diluída de modo seriado na razão 10, com concentração inicial de $0,36 \mu \mathrm{M}$. Como anticorpo secundário utilizou-se 0 anticorpo anti-lgG de camundongo específico para fragmento $F(a b \text { ') })_{2}$ conjugado com peroxidase para os fragmentos Fab anti-digoxina dos 4 clones e para o DigiFab ${ }^{\circledR}$ foi utilizado o anti-lgG de cabra conjugado com peroxidase.

A concentração necessária de digoxina para inibir em $50 \%$ a ligação entre os fragmentos Fab anti-digoxina e a Dig-BSA $\left(\mathrm{IC}_{50}\right)$ foi calculada, com o uso do programa GraphPad Prism. O DigiFab ${ }^{\circledR}$ apresentou o menor valor de $\mathrm{IC}_{50} 4,9 \times 10^{-6}$, enquanto que os fragmentos Fab do clone 9 apresentaram o maior valor $\left(8,1 \times 10^{-5}\right)$ (Figura 27). No ensaio ANOVA não foram verificadas diferenças estatísticas entre os fragmentos Fab dos clones 2 e 10 ao produto comercial, os fragmentos Fab dos clones 1 e 9 apresentaram diferenças significativas ao DigiFab ${ }^{\circledR}$.

Para a verificação da ligação entre os fragmentos Fab anti-digoxina aos análogos da digoxina, utilizou-se como inibidor a digoxigenina, que difere estruturalmente da digoxina pela ausência da porção glicona. Como observado para a digoxina a digoxigenina também foi capaz de inibir a ligação dos fragmentos Fab à Dig-BSA (Figura 28). Verificou-se também que a inibição da ligação entre o DigiFab ${ }^{\circledR}$ e a Dig-BSA foi obtida com as menores concentrações de digoxigenina. Entre os fragmentos Fab dos clones, as menores concentrações de digoxigenina que 
possibilitaram a inibição foram obtidas pelos fragmentos Fab do clone 2, repetindo o comportamento observado para a digoxina.

Figura $27-\mathrm{IC}_{50}$ obtida pelo uso da digoxina como inibidor.

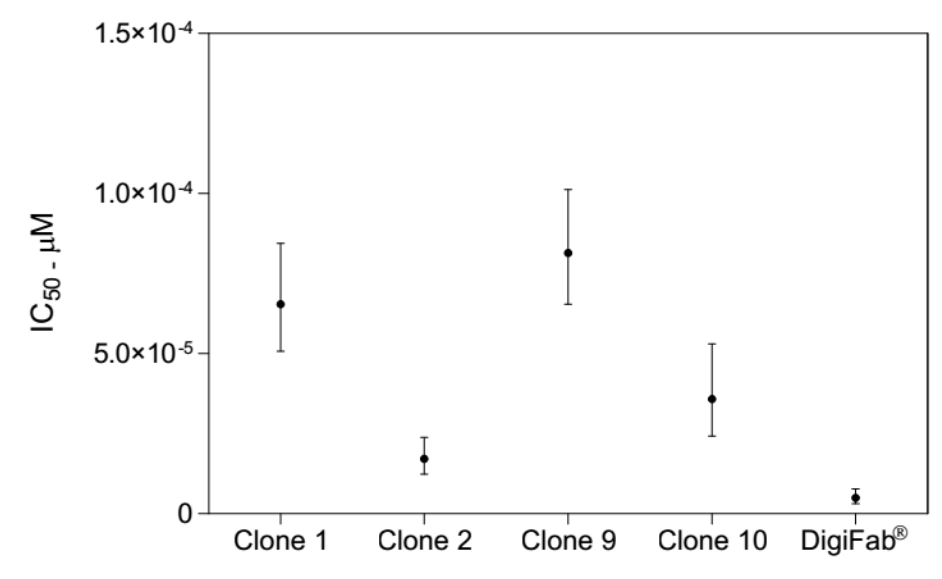

Figura 28 - ELISA de inibição da ligação entre os fragmentos Fab anti-digoxina e a Dig-BSA pela digoxigenina.

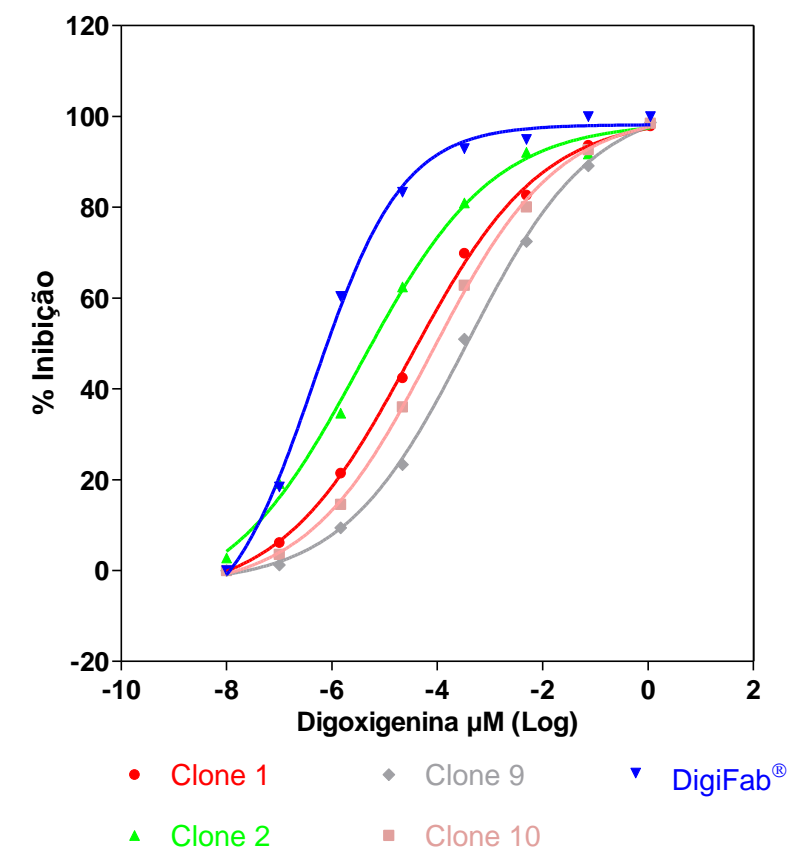

Sensibilização da placa com Dig-BSA a $4 \mu \mathrm{g} / \mathrm{mL}$. Os fragmentos Fab e o DigiFab ${ }^{\circledR}$ foram diluídos para $1 \mathrm{nM}$ em duplicata e misturados a digoxigenina diluída de modo seriado na razão 15 , com concentração inicial de $1,10 \mu \mathrm{M}$. Como anticorpo secundário utilizou-se o anticorpo anti-lgG de camundongo específico para fragmento $\left.\mathrm{F}(\mathrm{ab})_{2}\right)_{2}$ conjugado com peroxidase para os fragmentos $\mathrm{Fab}$ anti-digoxina dos 4 clones e para $\circ$ DigiFab $^{\circledR}$ foi utilizado 0 anti-IgG de cabra conjugado com peroxidase.

Com a obtenção do $\mathrm{IC}_{50}$ da digoxigenina, pode-se verificar que o fragmento Fab comercial apresentou o menor valor de $\mathrm{IC}_{50}\left(4,6 \times 10^{-7}\right)$ e o fragmento Fab do 
clone 9 o maior valor $\left(3,7 \times 10^{-4}\right)$ (Figura 29). Não foram verificadas diferenças significativas entre os fragmentos Fab dos 4 clones e $\circ$ DigiFab ${ }^{\circledR}$, pelo ensaio ANOVA.

Figura $29-\mathrm{IC}_{50}$ obtida pelo uso da digoxigenina como inibidor.

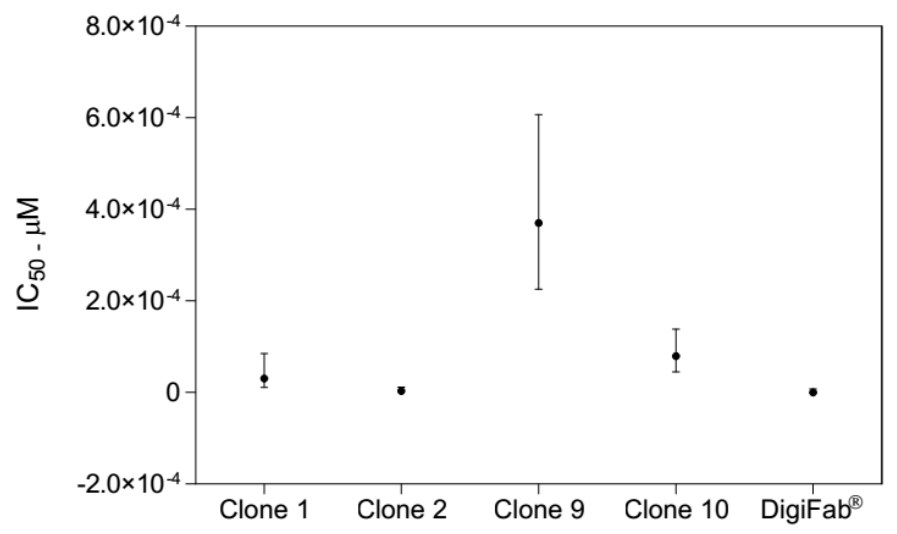

Continuando os ensaios de inibição utilizou-se a digitoxina como inibidor, que se diferencia da digoxina pela ausência de um grupo hidroxila na porção aglicona da molécula. Nas condições ensaiadas, não foi obtido o platô inferior correspondente a $0 \%$ de inibição para o DigiFab ${ }^{\circledR}$ (Figura 30), contudo o perfil apresentado na curva, sugere que menores concentrações de inibidor seriam capazes de interferir na ligação entre o DigiFab ${ }^{\circledR}$ e o conjugado Dig-BSA. Neste ensaio também se verificou que os fragmentos Fab do clone 1 necessitaram de menores concentrações de digitoxina para inibir a ligação ao conjugado Dig-BSA. Os resultados obtidos com os fragmentos Fab dos clones 9 e 10 foram semelhantes, mostrando que maiores concentrações de digitoxina são necessárias para impedir a ligação.

Com a ausência de uma curva de inibição compreendendo a faixa de 0 a $100 \%$ de inibição para o DigiFab $^{\circledR}$, não foi possível realizar o cálculo do $\mathrm{IC}_{50}$ e a análise estatística ANOVA para este material. Dos fragmentos Fab dos clones o menor valor de $\mathrm{IC}_{50}$ foi obtido pelo clone 1, seguido pelos clones 2, 10 e 9 (Figura 31). Pelo ensaio ANOVA verificou-se diferença significativa entre os 4 clones.

Finalizando os ensaios de inibição, a ouabaína foi utilizada como inibidor, esta se diferencia da digoxina por possuir estruturalmente apenas um açúcar frente a três existentes na digoxina e também pela mudança na posição de um grupo hidroxila. Os resultados obtidos pelo DigiFab ${ }^{\circledR}$, devem ser avaliados com cautela visto que, 
não foi obtida a curva compreendendo 0 e 100\% de inibição, porém os resultados obtidos indicam que menores concentrações de ouabaína seriam capazes de inibir a ligação à Dig-BSA. Os perfis de inibição encontrados foram semelhantes para os fragmentos Fab dos clones 1, 2, e 10. O clone 9 precisou de maiores concentrações de ouabaína para inibir a ligação com o material sensibilizado (Figura 32). Em virtude da falta de uma curva completa de inibição não foi possível fazer a análise ANOVA para o DigiFab ${ }^{\circledR}$. Os fragmentos Fab dos clones 1, 2 e 10 não apresentaram diferenças significativas entre si, porém o fragmento Fab do clone 9 apresentou diferença significativa aos fragmentos Fab dos clones 1, 2 e 10.

Figura 30 - ELISA de inibição da ligação entre os fragmentos Fab anti-digoxina e a Dig-BSA pela digitoxina.

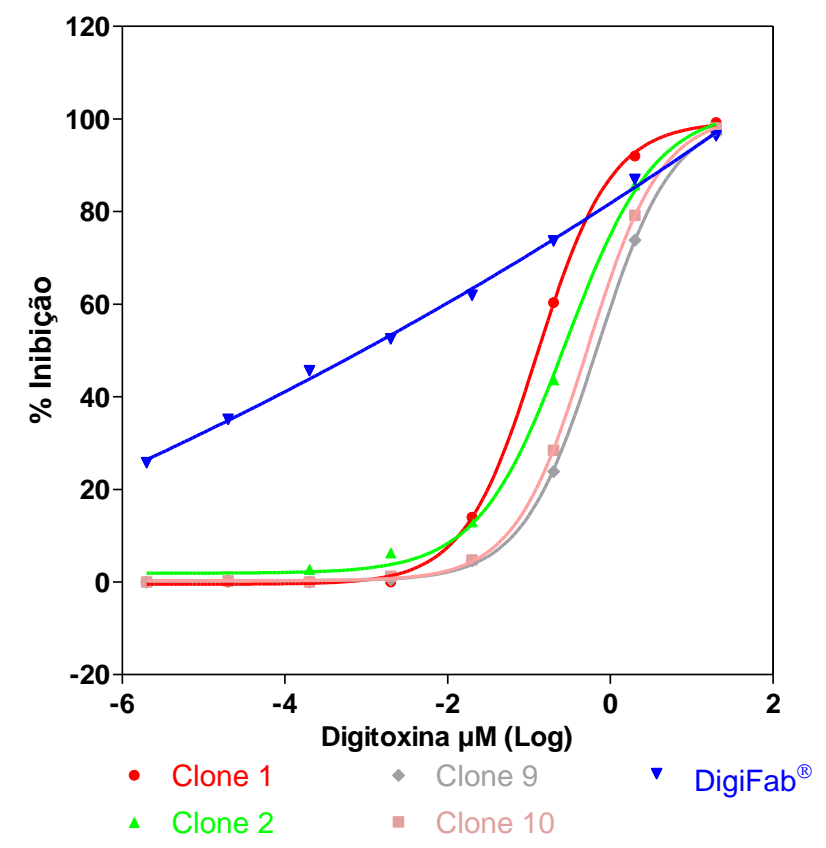

Sensibilização da placa com Dig-BSA a $4 \mu \mathrm{g} / \mathrm{mL}$. Os fragmentos Fab e o DigiFab ${ }^{\circledR}$ foram diluídos para $1 \mathrm{nM}$ em duplicata e misturados a digitoxina diluída de modo seriado na razão 10 , com concentração inicial de $20 \mu \mathrm{M}$. Como anticorpo secundário utilizou-se o anticorpo anti-lgG de camundongo específico para fragmento $\left.F\left(a^{\prime}\right)_{2}\right)_{2}$ conjugado com peroxidase para os fragmentos $F a b$ anti-digoxina dos 4 clones e para o DigiFab ${ }^{\circledR}$ foi utilizado o anti-lgG de cabra conjugado com peroxidase. 
Figura $31-\mathrm{IC}_{50}$ obtida pelo uso da digitoxina como inibidor.

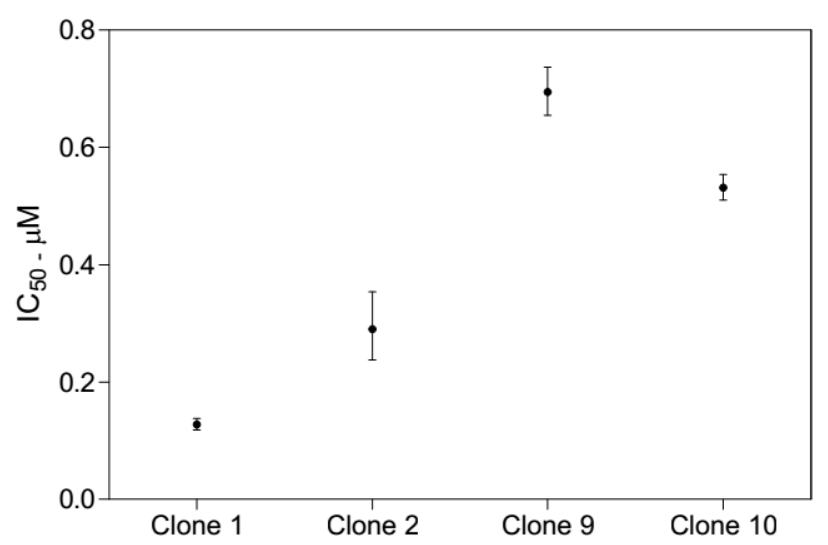

Figura 32 - ELISA de inibição da ligação entre os fragmentos Fab anti-digoxina e a Dig-BSA pela ouabaína.

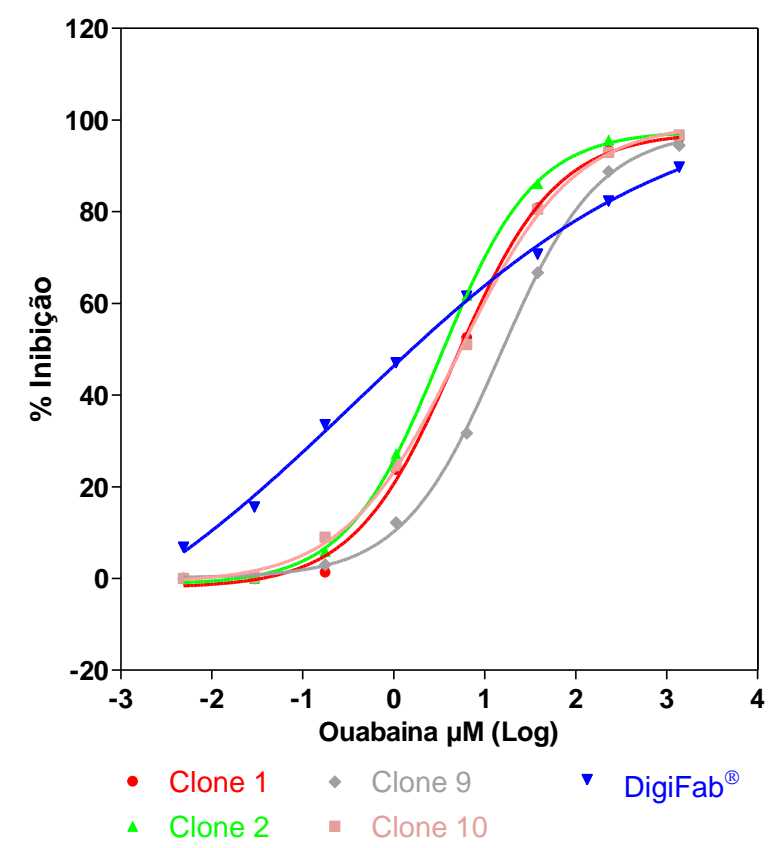

Sensibilização da placa com Dig-BSA a $4 \mu \mathrm{g} / \mathrm{mL}$. Os fragmentos Fab e o DigiFab ${ }^{\circledR}$ foram diluídos para $1 \mathrm{nM}$ em duplicata e misturados a ouabaína diluída de modo seriado na razão 6 , com concentração inicial de $1370 \mu \mathrm{M}$. Como anticorpo secundário utilizou-se o anticorpo anti-lgG de camundongo específico para fragmento $F\left(a b^{\prime}\right)_{2}$ conjugado com peroxidase para os fragmentos $F a b$ anti-digoxina dos 4 clones e para o DigiFab ${ }^{\circledR}$ foi utilizado o anti-lgG de cabra conjugado com peroxidase.

Pelo cálculo da $\mathrm{IC}_{50}$ para a ouabaína verifica-se uma tendência do DigiFab ${ }^{\circledR}$ em necessitar de uma menor quantidade de inibidor para impedir a ligação com à Dig-BSA, a medida que possui o menor valor de $\mathrm{IC}_{50}$, porém com elevado intervalo de confiança. Os valores de $\mathrm{IC}_{50}$ foram semelhantes entre os fragmentos Fab dos 
clones 1, 2, e 10. Os fragmentos Fab do clone 9 apresentou o maior valor de $I_{50}$ (Figura 33).

$\mathrm{Na}$ Tabela 9 estão apresentados os valores de $\mathrm{IC}_{50}$ obtidos nos ensaios de inibição com a digoxina e análogos avaliados. Entre os 4 clones de fragmentos Fab, o clone 9 apresentou os maiores valores de $\mathrm{IC}_{50} \mathrm{em}$ todos os ensaios realizados, $\mathrm{O}$ clone 2 exibiu os menores valores de $\mathrm{IC}_{50}$ para a digoxina, digoxigenina e ouabaina, porém para a digitoxina a menor $\mathrm{IC}_{50}$ foi obtida pelo clone 1 .

Figura $33-\mathrm{IC}_{50}$ obtida pelo uso da ouabaína como inibidor.

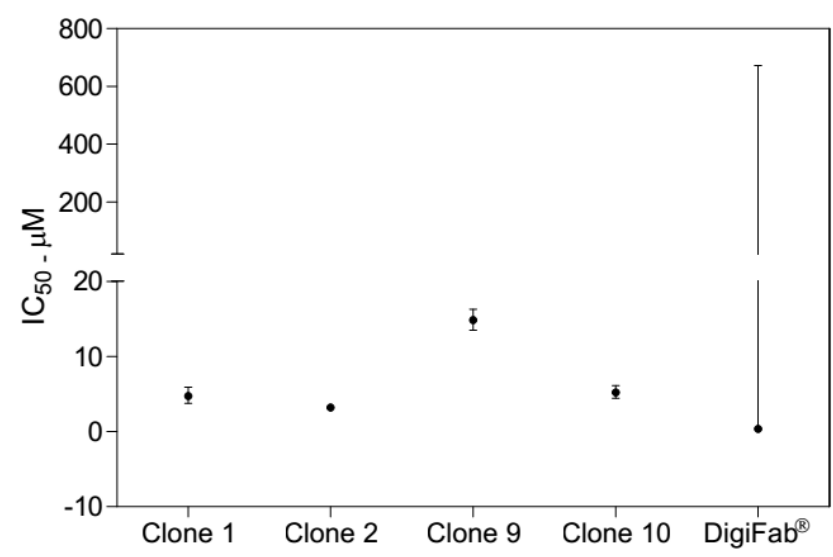

Tabela 9 - Valores de $\mathrm{IC}_{50}$.

$$
\mathrm{IC}_{50} \mu \mathrm{M}
$$

Digoxina Digoxigenina Digitoxina Ouabaína

\begin{tabular}{llllc}
\hline Clone 1 & $6,5 \times 10^{-5}$ & $3,1 \times 10^{-5}$ & 0,13 & 4,7 \\
Clone 2 & $1,7 \times 10^{-5}$ & $3,4 \times 10^{-6}$ & 0,29 & 3,2 \\
Clone 9 & $8,1 \times 10^{-5}$ & $3,7 \times 10^{-4}$ & 0,69 & 14,8 \\
Clone 10 & $3,6 \times 10^{-5}$ & $7,9 \times 10^{-5}$ & 0,53 & 5,2 \\
DigiFab $^{\circledast}$ & $4,9 \times 10^{-6}$ & $4,6 \times 10^{-7}$ & NC & 0,4 \\
\hline
\end{tabular}

NC - Não calculado

\subsubsection{Determinação dos parâmetros cinéticos de ligação}

Os parâmetros cinéticos da ligação entre os fragmentos Fab dos 4 clones e DigiFab $^{\circledR}$ (analitos) com o conjugado Dig-BSA (ligante) foram avaliados por SPR no equipamento Biacore T200. A metodologia utilizada foi a de titulação cinética, onde o conjugado Dig-BSA imobilizado no sensor recebeu a aplicação sequencial de concentrações crescentes dos analitos. 
Para a realização da titulação cinética foram obtidos os sensorgramas e o ajuste da curva conforme o modelo de Langmuir (1:1 - ligação de uma molécula do analito com uma do ligante). Na Figura 34 estão apresentadas as curvas observadas e calculadas para os fragmentos Fab, demonstrando, em todos os ensaios, que o ajuste (curva calculada) está adequado, o que significa que os dados cinéticos obtidos são coerentes.

Figura 34 - Sensorgramas das titulações cinéticas.
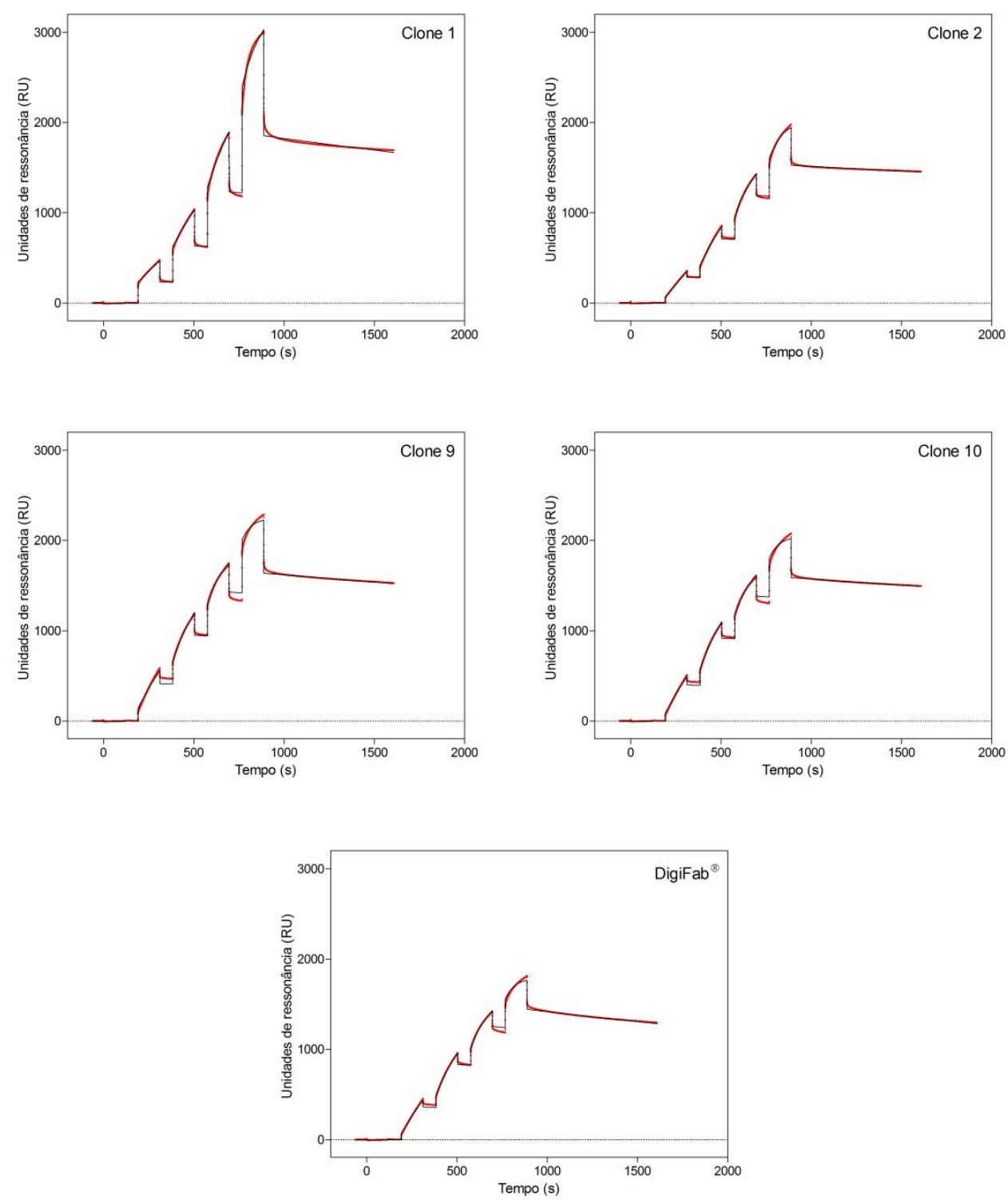

Titulação cinética, a $37^{\circ} \mathrm{C}$, fluxo de $30 \mu \mathrm{L} / \mathrm{min}$, contato de 120 s e dissociação por 720 s. Amostras diluídas a $0 ; 0,625 ; 1,25 ; 2,5$ e $5,0 \mu \mathrm{g} / \mathrm{mL}$ em solução HBS-EP. Regeneração com um pulso de $20 \mu \mathrm{L}$ da solução de SDS 0,5\%, glicina $100 \mathrm{mM} \mathrm{pH}$ 2,0. Linha vermelha RU observada, linha preta RU calculada. 
As velocidades de associação representadas pela constante de associação $\left(k_{a}\right)$, que corresponde ao tempo para a formação do complexo analito-ligante, foram determinadas. Os fragmentos Fab dos clones 9, 10 e o DigiFab ${ }^{\circledR}$, apresentaram as mais altas $k_{a}$, enquanto que o clone 1 mostrou o menor valor de $k_{a}$ (Figura 35, Tabela 10).

Com a determinação das velocidades de dissociação representadas pela constante de dissociação $\left(k_{d}\right)$, que demonstram a estabilidade do complexo formado. Verificou-se que a menor $k_{d}$ foi obtida pelos fragmentos Fab do clone 2, e a maior pelo DigiFab ${ }^{\circledR}$ (Figura 35, Tabela 10).

Figura 35 - Velocidade de associação x velocidade de dissociação

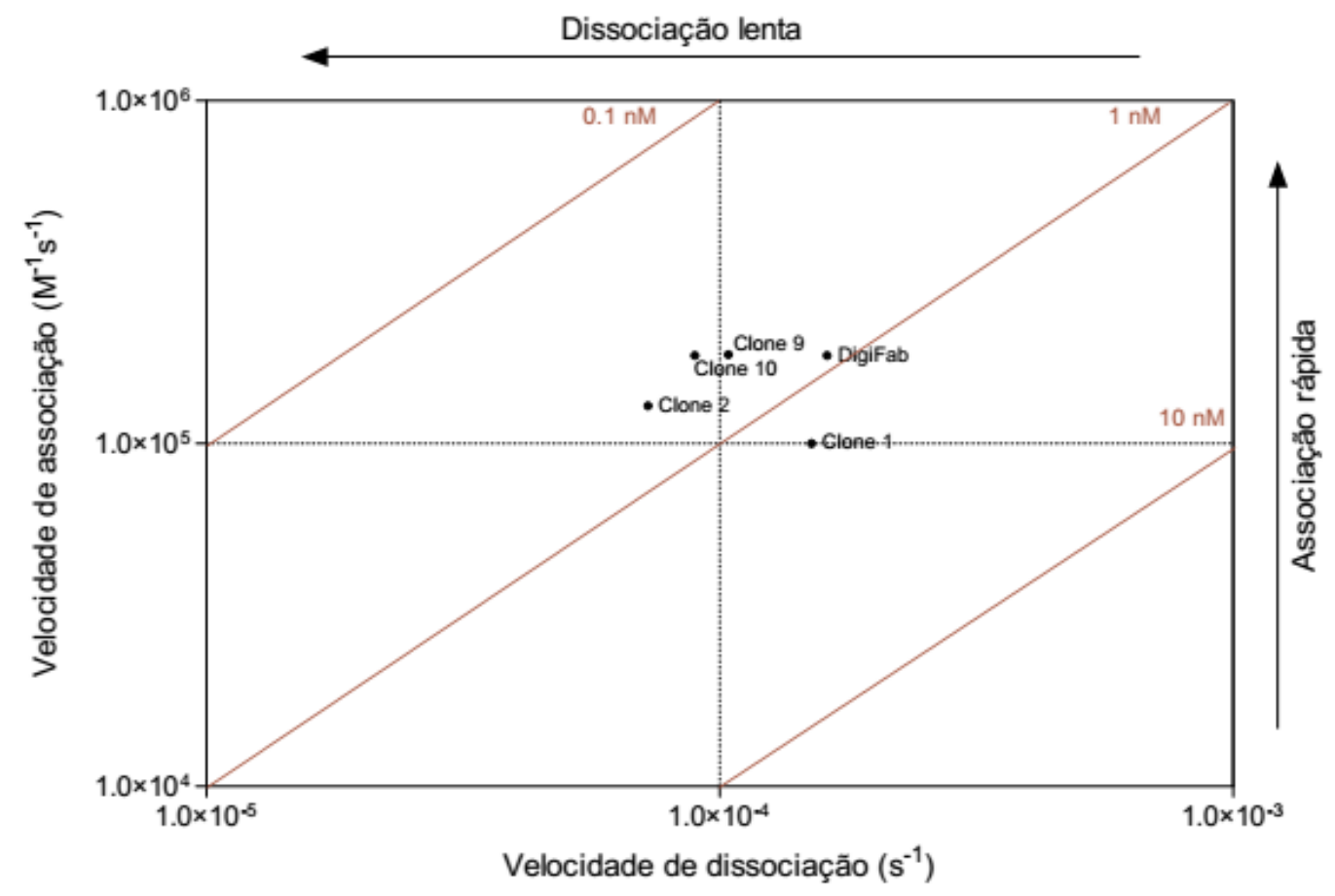

Com a obtenção dos parâmetros cinéticos, foi possível calcular as constantes de afinidade $-k_{D}$ (relação entre as velocidades de associação e dissociação dos materiais analisados).

Os fragmentos Fab dos 4 clones e o DigiFab ${ }^{\circledR}$ apresentaram $k_{D}$ similares, com variação entre $1,5 \times 10^{-9} \mathrm{M}$ (Clone 1) a $4,9 \times 10^{-10} \mathrm{M}$ (clone 10) (Figura 36, Tabela 10). 


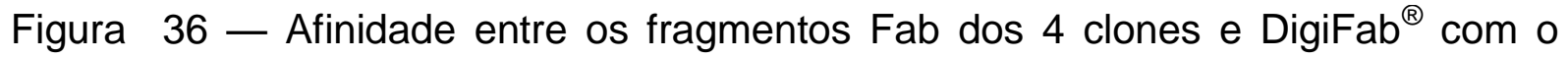
conjugado Dig-BSA.

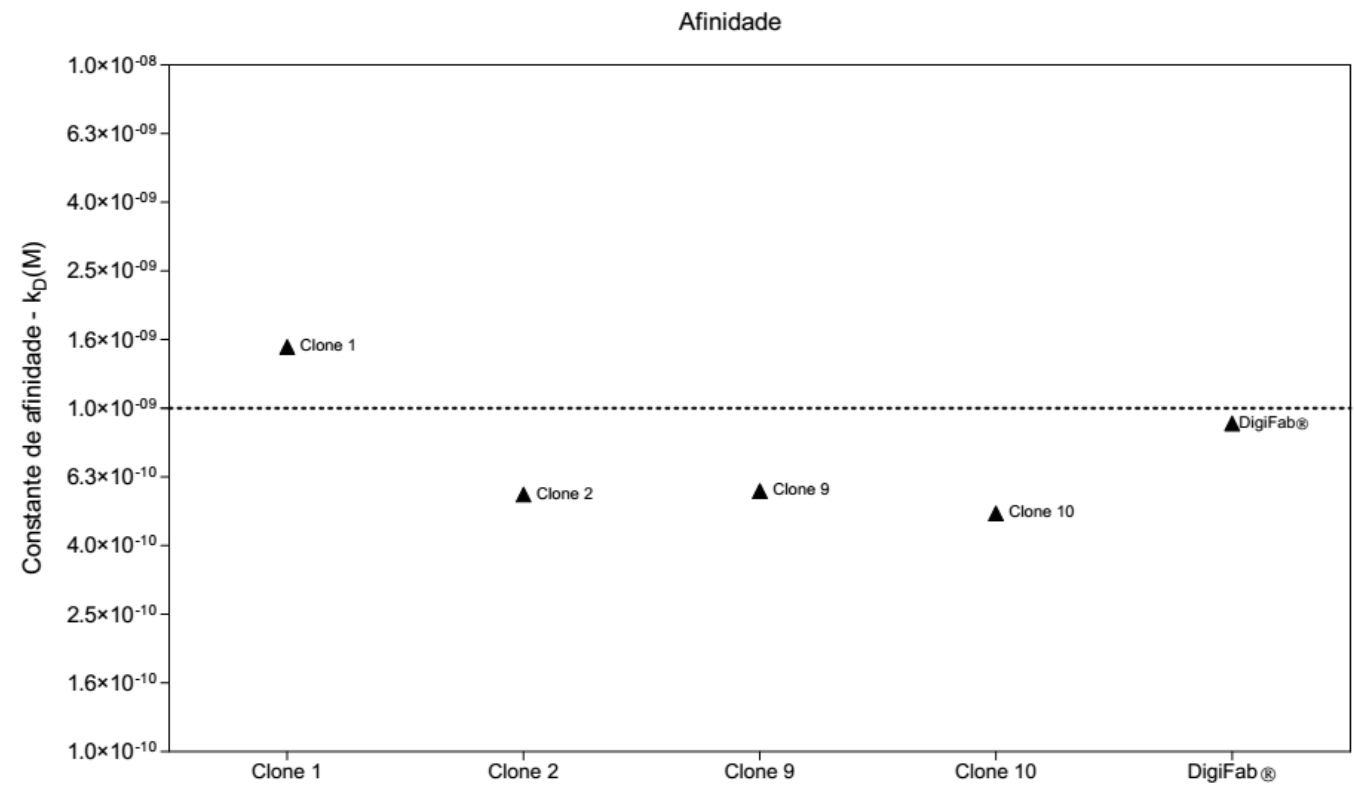

No ensaio estatístico ANOVA não foram observadas diferenças significativas entre as amostras analisadas.

Tabela 10 - Parâmetros cinéticos obtidos por SPR

\begin{tabular}{llll}
\hline & $\mathrm{k}_{\mathrm{a}}(\mathrm{M}-1 \mathrm{~s}-1)$ & $\mathrm{k}_{\mathrm{d}}(\mathrm{s}-1)$ & $\mathrm{K}_{\mathrm{D}}(\mathrm{M})$ \\
\hline Clone 1 & $1,00 \times 10^{5}$ & $1,51 \times 10^{-4}$ & $1,51 \times 10^{-9}$ \\
Clone 2 & $1,29 \times 10^{5}$ & $7,25 \times 10^{-5}$ & $5,61 \times 10^{-10}$ \\
Clone 9 & $1,82 \times 10^{5}$ & $1,04 \times 10^{-4}$ & $5,74 \times 10^{-10}$ \\
Clone 10 & $1,81 \times 10^{5}$ & $8,95 \times 10^{-5}$ & $4,94 \times 10^{-10}$ \\
DigiFab@ & $1,81 \times 10^{5}$ & $1,62 \times 10^{-4}$ & $9,04 \times 10^{-10}$ \\
\hline
\end{tabular}




\section{DISCUSSÃO}

Linhagens bacterianas Gram negativas como a $E$. coli possuem em sua estrutura uma membrana interna e outra externa, dividindo o organismo em 2 compartimentos: o citoplasma e o periplasma. Proteínas recombinantes, após expressão no citoplasma bacteriano, podem ser direcionadas para qualquer um destes compartimentos ou serem liberadas para o sobrenadante da cultura ( $\mathrm{CHOI}$ et al., 2006). A presença dos peptídeos sinais ompA e pelB no vetor fagomídeo pComb3XTT, direcionam respectivamente a cadeia leve e a porção $V_{H}$ e $C_{H} 1$ da cadeia pesada do fragmento Fab anti-digoxina para o espaço periplasmático. No periplasma os peptídeos sinais são clivados por peptidases sinal (CHOI; LEE, 2004).

As vantagens obtidas no transporte das cadeias polipeptídicas para 0 periplasma em relação ao citoplasma são: ser um local com menor atividade proteolítica; simplificar a purificação da proteína recombinante, por conter apenas $4 \%$ do total de proteína celular; facilitar a correta formação de pontes dissulfeto, por ser um ambiente mais oxidativo e possuir proteínas da família da thioredoxina (DsbA, DsbB e DsbC) que catalisam a formação de pontes dissulfeto, de fundamental importância para as formações das 4 pontes intra-cadeia e uma intercadeia necessárias para a integridade estrutural e funcional requeridas pela molécula de Fab (LU; HOLMGREN, 2014; SCHUMANN; FERREIRA, 2004; WHITE, 2007).

A expressão do fragmento Fab solúvel foi verificada no sobrenadante do cultivo, no espaço periplasmático e no lisado bacteriano total, pelo ensaio de Western blotting, onde se detectou a existência de dois componentes, um correspondente ao fragmento Fab anti-digoxina com massa de $50 \mathrm{kDa}$ e outro com $25 \mathrm{kDa}$ (Figura 6). A existência de material com peso molecular de $25 \mathrm{kDa}$ pode indicar uma dissociação dos fragmentos Fab, visto que a cadeia leve $\left(V_{L}, C_{L}\right)$ e a $V_{H}$, $\mathrm{C}_{\mathrm{H}} 1$ da cadeia pesada, possuem $25 \mathrm{kDa}$. Outra hipótese deve-se à expressão das cadeias serem realizadas de forma isolada e não terem sido unidas pela ponte de dissulfeto.

A maior concentração de fragmentos Fab foi verificada no sobrenadante da cultura (Tabela 3), possivelmente pelo fato das proteínas de baixo peso molecular presentes no periplasma bacteriano serem liberadas para o meio extracelular, 
devido ao aumento da permeabilidade da membrana externa em longos períodos de incubação (CHOI; LEE, 2003). A obtenção da proteína de interesse no sobrenadante do cultivo ou no espaço periplasmático possibilita maior facilidade no processamento downstream e a redução no custo do processo quando comparado com a produção da proteína no citoplasma celular (YOON et al., 2010), além de não necessitar de processo de desnaturação e renaturação.

Estão disponíveis poucas metodologias para a purificação de fragmentos Fab, dentre elas a utilização de resinas de afinidade e resinas de troca iônica - catiônica e aniônica. Além de poucas alternativas, ainda não foi desenvolvido um método aplicável de forma genérica a diferentes fragmentos de anticorpos com elevada pureza e rendimento (RODRIGO; GRUVEGÅRD; ALSTINE, 2015), fazendo-se necessária a avaliação de diferentes estratégias para o isolamento deste material.

Para a purificação dos fragmentos Fab anti-digoxina foram testadas as resinas de afinidade Capto $^{\mathrm{TM}} \mathrm{L}$, proteína $\mathrm{G}$ Sepharose $4 \mathrm{FF}$ e as resinas de troca iônica Q Sepharose FF e S Sepharose FF. A utilização da resina Capto ${ }^{\mathrm{TM}} \mathrm{L}$ que possui afinidade pelo tipo kappa da cadeia leve, subtipos humanos 1, 3, 4 e subtipo murino 1, não foi eficaz para a purificação dos fragmentos Fab anti-digoxina na condição avaliada, sugerindo que o fragmento Fab não seja do subtipo kappa 1. A resina proteína $G$, que possui alta taxa de afinidade à porção $F c$ do anticorpo e afinidade fraca pela região constante da cadeia pesada $\left(C_{H} 1\right)$ apresentou capacidade de purificação. No entanto, houve variação na pureza dos fragmentos Fab de cada clone (Figura 9). A diferença na pureza entre os clones obtidos pela purificação em resina de proteína $G$ pode ter sido ocasionada pela suscetibilidade de agregação dos clones quando expostos a diferentes condições de estresse. Esta hipótese é baseada na ausência desta diferença quando os fragmentos Fab foram aplicados na forma reduzida ao gel de eletroforese (Figura 9b). Em geral os anticorpos e os fragmentos de anticorpos tendem a agregar quando estão em alta concentração, ciclos de congelamento e descongelamento, agitação, baixo pH, elevadas temperaturas e por longos períodos de armazenamento $(\mathrm{CHOI}$, et al., 2006; PERCHIACCA, TESSIER, 2012). Fragmentos de anticorpos contendo agregados exibem imunogenicidade e toxicidade aumentadas e alterações nas propriedades terapêuticas e farmacocinéticas (GIL; SCHRUM, 2013), portanto devem ser eliminadas do material final. 
Com a finalidade de se obter maior quantidade de fragmentos Fab e avaliar 0 nível de pureza a ser obtido pela purificação dos fragmentos Fab presentes no periplasma, foi realizada a lise da membrana externa por choque osmótico seguida pela purificação em coluna de proteína G. Foi observado que o nível de pureza obtido pelos produtos provenientes da lise do periplasma foi inferior ao obtido com a purificação do sobrenadante da cultura (Figura 10).

Com a disponibilidade, nesta etapa do trabalho, de uso do fragmento Fab comercial - DigiFab ${ }^{\circledR}$ como referência para os ensaios de caracterização dos fragmentos Fab, a comparação só seria possível com o mesmo nível de pureza para todos os produtos.

Visando a melhoria no grau de pureza dos fragmentos monoclonais avaliou-se a adição de uma etapa cromatográfica em resina S Sepharose, posterior à etapa de captura em resina de proteína $\mathrm{G}$ em dois ensaios com abordagens distintas. Entretanto, os resultados não foram satisfatórios (Figuras 11 e 12).

O uso da resina $Q$ Sepharose FF foi avaliado, com a aplicação do sobrenadante da cultura à coluna cromatográfica. Nesta abordagem, moléculas com $\mathrm{pH}$ ácido como endotoxinas e DNA presentes no sobrenadante se ligariam à resina, enquanto que os fragmentos Fab seriam coletados na fração não ligada (SPITALI, 2009). Além da existência de contaminantes em todas as frações analisadas, não foi observada melhoria neste procedimento. Contudo, a etapa foi importante para verificar que as modificações estruturais ou agregados dos fragmentos Fab ocorreram durante a etapa de ajuste do pH (Figura 15), como também foi observado por Shukla et al. (2005).

Utilizando das observações dos resultados anteriores, foi desenhada a abordagem cromatográfica com o uso em uma etapa inicial da coluna S Sepharose seguida pela utilização da coluna de proteína $G$, condição em que foi obtido o nível de pureza desejado para os fragmentos Fab dos 4 clones (Figura 22). Na etapa inicial desta abordagem cromatográfica foi verificada que, apesar dos perfis cromatográficos serem semelhantes (Figura 20), existiu diferença na interação dos materiais à resina catiônica, sendo que os produtos dos clones 1 e 10 foram removidos da coluna com o aumento do $\mathrm{pH}$, enquanto que para os clones 2 e 9 era necessário, além do aumento de $\mathrm{pH}$, o aumento da força iônica na solução de eluição. Na etapa cromatográfica posterior (proteína $\mathrm{G}$ ) foi observada que a fração 
contendo o fragmento Fab do clone 10 possui um pico definido, com boa resolução e os produtos dos clones 1,2 e 9 , resolução mais baixa. O material do clone 10 também apresentou os melhores rendimentos nas duas etapas cromatográficas. Com base nestas informações pode-se dizer que esta estratégia cromatográfica foi mais adequada para a purificação do fragmento Fab do clone 10 (Figura 21, Tabela 8).

Diferentemente do observado por Jalalirade (2013) na purificação do fragmento Fab D1.3 anti-lisozima (proveniente de cultivo bacteriano e com a utilização apenas da resina de proteína $G$ para o seu isolamento), que verificou um baixo rendimento de purificação (1\%), o produto do clone 10 alcançou rendimento de $44 \%$ (Tabela 4), utilizando a mesma resina. O uso sequencial das resinas $S$ Sepharose e proteína $G$ para a purificação do fragmento Fab D1.3 também foi avaliado por Jalalirade (2013), que neste caso observou uma recuperação de $83 \%$. O rendimento obtido pelo produto do clone 10 , com o uso desta abordagem foi de 25\% (Tabela 7).

A avaliação do perfil isoelétrico dos fragmentos Fab dos 4 clones, mostrou diferenças tanto na quantidade de isoformas existentes quanto no ponto isoelétrico (Figura 23), o que pode justificar os graus diferentes de interação com a resina catiônica. O DigiFab ${ }^{\circledR}$, um anticorpo policlonal, apresentou o pl mais alcalino do que o observado para os fragmentos Fab dos clones, com um certo grau de arraste, resultado comum para anticorpos policlonais.

A especificidade de ligação entre os fragmentos Fab anti-digoxina e o antígeno Dig-BSA foi confirmada pelos ensaios de Western blotting (Figura 24) e ELISA método 2 (Figura 25), não sendo verificadas ligações entre os fragmentos Fab com a BSA, demonstrando a especificidade de ligação dos materiais à porção digoxina do conjugado Dig-BSA.

Com o ensaio de ELISA de inibição foi possível verificar a especificidade entre os fragmentos Fab anti-digoxina dos 4 clones e do $\operatorname{DigiFab}^{\circledR}$ à digoxina, digoxigenina, digitoxina e a ouabaína (Figuras 26, 28, 30 e 32). De modo semelhante ao observado no trabalho realizado por Pullen et al. (2008) que verificou a baixa afinidade do Digibind ${ }^{\circledR}$ e DigiFab ${ }^{\circledR}$ à ouabaína em um ensaio competitivo, os fragmentos Fab dos 4 clones e o DigiFab ${ }^{\circledR}$, também apresentaram baixa afinidade a este análogo, no ensaio de ELISA de inibição. 
Os valores de $\mathrm{IC}_{50}$ obtidos sugerem que, nas condições experimentais, as alterações estruturais dos análogos avaliados, quando presentes na porção não açúcar, tiveram maior interferência na formação dos complexos inibidor-Fab, do que quando existentes na porção açúcar. A digitoxina difere da digoxina apenas pela ausência de um grupo hidroxila na porção aglicona e a ouabaína, na quantidade de açúcar e na mudança da posição de um grupo hidroxila na porção aglicona (KATZ et al., 2010). Para estes análogos foram obtidos os maiores valores de $I_{50}$, enquanto aqueles obtidos pela digoxigenina, que não possui a porção glicona (KATZ et al., 2010) e a digoxina apresentaram os menores valores (Figuras 27, 29, 31 e 33; Tabela 9). $O$ DigiFab ${ }^{\circledR}$, apesar de não ter resultado em valor de $I_{50}$ para digitoxina e apresentar um elevado intervalo de confiança para a ouabaína, nas condições avaliadas, obteve os menores valores de $\mathrm{IC}_{50}$. Cabe ressaltar que, sendo este um produto de origem policlonal, as variações existentes entre os glicosídeos testados exerceriam uma menor influencia na ligação destes ao DigiFab ${ }^{\circledR}$. Todavia, os fragmentos $\mathrm{Fab}$ dos 4 clones, que são monoclonais, tiveram seus valores de $\mathrm{IC}_{50}$ próximos aos obtidos pelo produto policlonal (Tabela 9).

Com o uso do ensaio de titulação cinética por SPR foi possível determinar os parâmetros cinéticos de interação entre os fragmentos Fab dos 4 clones e do DigiFab® com o conjugado Dig-BSA (Figura 34). As características desejadas para os fragmentos Fab são: possuir alta velocidade de associação $\left(k_{a}\right)$, revertendo rapidamente a toxicidade causada pela digoxina; baixa velocidade de dissociação $\left(k_{d}\right)$, possibilitando a eliminação do complexo fragmento Fab-digoxina pela via renal e elevada taxa de afinidade $\left(K_{D}\right)$, o que permitiria o uso de menores quantidades de fragmentos Fab.

Apesar das características almejadas para os parâmetros cinéticos é necessário que a sua avaliação seja efetuada com critério e em conjunto, visto que materiais com a mesma $K_{D}$ podem possuir diferenças nas velocidades de associação e dissociação, como o observado pelos fragmentos dos clones 2 e 9 que possuem afinidades semelhantes, porém com velocidades de associação e dissociação diferentes (Figura 35, Tabela 10). A estabilidade entre o complexo antígeno-anticorpo, que é avaliada pela velocidade de dissociação no ensaio de SPR, tem fundamental importância na escolha de um clone produtor de anticorpos (CANZIANI; KLAKAMP; MYSZKA, 2004; HAHNEFELD; DREWIANKA; HERBERG, 
2004). A afinidade descrita do $\operatorname{DigiFab}^{\circledR}$ à digoxina compreende a faixa de $10^{-9}$ a $10^{-10} \mathrm{M}$ (PROTHERICS, 2001). Nas condições avaliadas observou-se que tanto o DigiFab $^{\circledR}$ quanto os fragmentos Fab dos clones 2, 9 e 10 apresentaram este mesmo nível de afinidade (Figura 36, Tabela 10).

Em suma, nas condições experimentais, o produto do clone 1 foi inferior aos demais tanto no rendimento de purificação quanto na afinidade verificada por SPR. Os produtos dos clones 2 e 9 apresentaram rendimentos de purificação e constantes de afinidade semelhantes, porém o clone 9 obteve uma baixa concentração de fragmentos Fab no sobrenadante da cultura, aproximadamente $1 / 3$ inferior ao obtido pelos outros clones. $O$ clone 10 atingiu os melhores rendimentos de purificação e de afinidade ao conjugado Dig-BSA.

A avaliação de diferentes estratégias cromatográficas para a purificação dos fragmentos Fab anti-digoxina, aliada a possibilidade de obtenção de um produto monoclonal homogêneo, produzido sem o uso de animais e com características semelhantes ao produto disponível, tornou atraente a realização do presente trabalho e as suas conclusões. 


\section{CONCLUSÕES E PERSPECTIVAS}

Os experimentos de purificação e caracterização realizados com os fragmentos Fab dos 4 clones selecionados permitem a escolha do clone mais adequado para otimizar o processo upstream, visando escalonamento do produto.

A estratégia de purificação utilizada traz vantagens como a aplicação direta do sobrenadante do cultivo bacteriano sem a necessidade de diafiltração e a aplicação direta do eluato da troca iônica na resina de afinidade, que proporciona concentração do produto no eluato. O conjunto de procedimentos downstream realizado proporciona fácil escalonamento.

A existência de especificidade entre os fragmentos Fab produzidos e a digoxigenina (metabólito ativo da digoxina) permite a utilização também no mercado da pesquisa e diagnóstico, visto que o uso da digoxigenina como marcador para detecção de ácidos nucleicos e proteínas vem aumentando fortemente nos últimos anos. Este aumento deve-se à necessidade de evitar o uso de sistemas de detecção por radioatividade, tanto em pesquisa quanto em laboratórios clínicos. A utilização deste método com digoxigenina possui diversas vantagens, destacando o curto tempo de desenvolvimento do ensaio, alta resolução histológica e alta sensibilidade de detecção. A sonda de digoxigenina marcada tem menor custo do que as sondas marcadas com radioisótopos, que necessitam de instalações especiais, além do acúmulo de lixo radioativo e o risco causado pela radiação. Este método de detecção de ácidos nucleicos utiliza anticorpos com alta afinidade pela digoxigenina, conjugados ou não, para a identificação por quimioluminescência ou colorimetria (HART, BASU, 2009; McCREERY, 1997), podendo ser uma segunda aplicação do produto obtido no presente projeto.

As vantagens obtidas pelo produto gerado por engenharia genética em relação ao fragmento Fab anti-digoxina comercial são: ser um produto monoclonal, portanto, possível de ser produzido com homogeneidade, e não utilizar animais para a produção, contribuindo para evitar a contaminação por agentes infectantes de origem animal.

Os objetivos propostos neste trabalho foram alcançados, porém, para tornar viável a produção em maior escala dos fragmentos Fab obtidos, é necessária a realização de ensaios de otimização do nível de expressão do fragmento Fab anti- 
digoxina na cultura bacteriana, como: a avaliação de diferentes vetores e linhagens bacterianas; otimização das condições de expressão, pelo ajuste nas concentrações de IPTG, temperatura e tempo de indução; utilização de biorreatores, permitindo o controle do pH e o aumento da aeração.

O conjunto de resultados obtidos indica a possibilidade de desenvolvimento de um fragmento Fab monoclonal, obtido por fermentação bacteriana, como antídoto para a toxicidade da digoxina, seja no controle da medicação utilizada na cardiologia como em outros acidentes causados por ingestão, deliberada ou não, de plantas contendo digitálicos. 


\section{REFERÊNCIAS*}

ABBAS, A. et al. Imunologia celular e molecular. Rio de Janeiro: Elsevier, 2011. $592 \mathrm{p}$.

AHMED, A. Digoxin and reduction in mortality and hospitalization in geriatric heart failure: importance of low doses and low serum concentrations. Journal of Gerontology: Medical Sciences, v. 62ª , p. 323-329, 2007.

AMBROSY, A. P. et al. The use of digoxin in patients with worsening chronic heart failure: reconsidering an old drug to reduce hospital admissions. Journal of the American College of Cardiology, v. 63, p. 1823-1832, 2014.

ANDRÉS, V. L. G. Revisión sistemática sobre la efectividad e indicaciones de los anticuerpos antidigoxina en la intoxicación digitálica. Revista Española de Cardiología, v. 53, p. 49-58, 2000.

ANDREW, S. M.; TITUS, J. A. Purification of immunoglobulin G. Current protocols in cell biology, p. 16.3.1-16.3.12, 2000.

ANTMAN, E. M. et al. Treatment of 150 cases of life-threatening digitalis intoxication with digoxin-specific Fab antibody fragments. Final report of a multicenter study. Circulation, v. 81, p. 1744-1752, 1990.

ANTMAN, E. M.; SMITH, T. W. Digitalis toxicity. Annual Review of Medicine, v. 36, p. 357-367, 1985.

BAGROV, A. Y.; SHAPIRO, J. I.; FEDOROVA, O. V. Endogenous cardiotonic steroids: physiology, pharmacology and novel therapeutic targets. Pharmacology Reviews, v. 61, n. 9, p. 9-38, 2009.

BARBAS, C. F. et al. Phage display: a laboratory manual. New York: Cold Spring Harbor Laboratory Press, 2001.

BARROS, I. C. M. Monitorização terapêutica das concentrações plasmáticas da digoxina em pacientes com insuficiência cardíaca. Dissertação (Mestrado) Universidade Federal de Goiás, 2008.

BAZAN, J.; CALKOSINSKI, I.; GAMIAN, A. Phage display - A powerful technique for immunotherapy. Human Vaccines \& Immunotherapeutics, v. 8, n. 12, p. 18171828, 2012.

\footnotetext{
*De acordo com:

ASSOCIAÇÃO BRASILEIRA DE NORMAS TÉCNICAS. NBR 6023: informação e documentação: referências: elaboração. Rio de Janeiro, 2002.
} 
BOCCHI, E. A. et al. Sociedade Brasileira de Cardiologia. III Diretriz brasileira de insuficiência cardíaca crônica. Arquivo Brasileiro de Cardiologia, v. 93, p. 1-71, 2009. Supl. 1.

BOURGE, R. C. et al. Digoxin reduces 30-day all-cause hospital admission in older patients with chronic systolic heart failure. The American Journal of Medicine, v. 126, p. 701-708, 2013.

BRASIL. Ministério da Saúde. Agência Nacional de Vigilância Sanitária. Resolução - RDC n.o 8, de 28 de fevereiro de 2014. Brasil, 2014. Disponível em: <http://portal.anvisa.gov.br/wps/wcm/connect/ba66ce00433dbaa5a974ab9a5300951 3/RDC_7_2014+(suspens\%C3\%A30_arq_temp).pdf?MOD=AJPERES>. Acesso em: 18 dez. 2015.

. Ministério da Saúde. Agência Nacional de Vigilância Sanitária. Resolução RDC $\mathrm{n}^{\circ}$ 28, de 09 de maio de 2008. Brasil, 2008. Disponível em: <http://bvsms.saude.gov.br/bvs/saudelegis/anvisa/2008/res0028_09_05_2008.html>. Acesso em: 18 dez. 2015.

- Ministério da Saúde. Secretaria de Ciência, Tecnologia e Insumos Estratégicos Departamento de Assistência Farmacêutica e Insumos Estratégicos. Relação Nacional de Medicamentos Essenciais - RENAME. Brasil, 2015. Disponível em: <http://bvsms.saude.gov.br/bvs/publicacoes/relacao_nacional_medicamentos_essen ciais_rename_2014.pdf>. Acesso em: 18 dez. 2015.

BTG. DigiFab ${ }^{\circledR}$ Technical Leaflet, London, 2012

BUTLER, V. P. JR; CHEN, J. P. Digoxin-specific antibodies. Proceedings of the National Academy of Sciences of the United States of America, v. 57, p. 71-78, 1967.

CANZIANI, G. A.; KLAKAMP, S.; MYSZKA, D. G. Kinect screening of antibodies from crude hybridoma sample using Biacore. Analytical Biochemistry, v. 325, p. 301307, 2004.

CHAN, B. S.; BUCKLEY, N. A. Digoxin-specific antibody fragments in the treatment of digoxin toxicity. Clinical Toxicology, v. 52, n. 8, p. 824-836, 2014.

CHOI, J. H.; KEUM, K. C.; LEE, S. Y. Production of recombinant proteins by high cell density culture of Escherichia coli. Chemical Engineering Science, v. 61, p. 876885, 2006.

CHOI, J. H.; LEE, S. Y. Secretory and extracellular production of recombinant proteins using Escherichia coli. Applied Microbiology and Biotechnology, v. 64, p. 625-635, 2004.

EICHHORN, E. J.; GHEORGHIADE, M. Digoxin. Progress in Cardiovascular Diseases, v. 44, n. 4, p. 251-266, 2002. 
ERIKSSON, K.-O. Hydrophobic interaction chromatography. In: JANSON, J.-C.; RYDEN, L. (Ed.). Protein purification: principles, high resolution methods, and applications. 2nd ed. New York: John Wiley \& Sons, 1998. p. 283-309.

FLANAGAN, R. J.; JONES A. L. Fab antibody fragments. Drug Safety, v. 27, n. 14, p. 1115-1133, 2004.

GALVÃO, T. F. et al. Antídotos e medicamentos utilizados para tratar intoxicações no Brasil: necessidades, disponibilidade e oportunidades. Caderno de Saúde Pública, v. 29, S167-S177, 2013. Sup.

GHEORGHIADE, M. et al. Contemporary use of digoxin in the management of cardiovascular disorders. Circulation, v. 113, p. 2556-2564, 2006.

GHEORGHIADE, M.; PITT B. Digitalis Investigation Group (DIG) trial: a stimulus for further research. American Heart Journal, v. 134, p. 3-12, 1997.

GHOSE, S. et al. Integrated polishing steps for monoclonal antibody purification. In: GOTTSCHALK, U. (Ed.) Process scale purification of antibodies. New Jersey: John Wiley \& Sons, 2009. p. 145-167.

GIL, D.; SCRUM, A. Strategies to stabilize compact folding and minimize aggregation of antibody-based fragments. Advances in Bioscience and Biotechnology, v. 4, p. 73-84, 2013.

GOLDBERGER, Z. D.; ALEXANDER, G. C. Digitalis use in contemporary clinical practice: refitting the foxglove. JAMA Internal Medicine, v. 174, n. 1, p. 151-154, 2014.

GUIMARÃES, J. I. et al. Revisão das II Diretrizes da Sociedade Brasileira de Cardiologia para Diagnóstico e Tratamento da Insuficiência Cardíaca. Arquivos Brasileiros de Cardiologia, v. 79, n. 4, p. 1-30, 2002.

HAHNEFELD, C.; DREWIANKA, S.; HERBERG, F. W.; DECKER, J (Ed); REISCHL, $E(E d)$, Determination of kinetic data using surface resonance biosensors. Molecular Diagnosis of infectious Diseases, v. 942 ed, p. 299-320, 2004.

HART, S. M.; BASU, C. Optimization of a Digoxigenin-based Immunoassay System for Gene Detection in Arabidopsis thaliana. Journal of biomolecular techniques, v. 20, p. 96-100, 2009.

HERMANS, P; ADMAS, H; DETMERS, F. Purification of antibodies and antibody fragments using CaptureSelect ${ }^{\mathrm{TM}}$ affinity resins. In: OSSIPOW, V.; FISCHER, N. (Ed.). Monoclonal antibodies methods and protocols. 2nd ed. New York: Humana Press, 2014. p. 297-314.

JALALIRAD, R. Efficient chromatographic processes for elevated purification of antibody fragment (Fab D1.3) from crude Escherichia coli culture. Biotechnology, v. 12, n. 2, p. 74-80, 2013. 
JOHNSON, A. R.; CROUCH, B.; ZANE HOROWITZ, B. Discrepancies in reported US pricing information for digoxin-Fab. Clinical Toxicology, v. 53, n. 1, p. 71, 2015.

KARLSSON, E.; RYDEN, L.; BREWER, J. Ion-Exchange Chromatography. In: JANSON, J.-C.; RYDEN, L. (Ed.). Protein purification: principles, high resolution methods, and applications. 2nd ed. New York: John Wiley \& Sons, 1998. p. 145-205.

KATZ, A. et al. Selectivity of digitalis glycosides for isoforms of human $\mathrm{Na}$, KATPase. Journal of biological chemistry, v. 285, n. 25, p. 19582-19592, 2010.

KOHLER, G.; MILSTEIN, G. Continuos culture of fused cells secreting antibody of predefined specificity. Nature, v. 7, n. 256, p. 495-497, 1975.

LU, J.; HOLMGREN, A. The thioredoxin superfamily in oxidative protein folding. Antioxidants \& Redox Signaling, v. 21, n. 3, p. 457-470, 2014.

MARQUES, B. F.; ROUSH, D. J.; GÖKLEN, K. E. Virus filtration of highconcentration monoclonal antibody solutions. Biotechnology Progress, v. 25, n. 2, p. 483-491, 2009.

McCREERY, T. Digoxigenin labeling. Molecular Biotechnology, v. 7, p. 121-124, 1997.

MORO, A. M.; RODRIGUES, M. T. A. Anticorpos monoclonais para a clínica. Biotecnologia Ciência \& Desenvolvimento, v. 4, n. 22, p. 32-35, 2001.

MURATA, V. M. et al. Anti-Digoxin Fab variants generated by Phage Display. Molecular Biotechnology, v. 54, p. 269-277, 2013

MURATA, V. M. Produção e caracterização da porção Fab do anticorpo antidigoxina utilizando a tecnologia de phage display. Dissertação (Mestrado) Universidade de São Paulo, 2012.

PERCHIACCA, J. M.; TESSIER, P. M. Engineering aggregation-resistant antibodies. Annual Review of Chemical and Biomolecular Engineering, v. 3, p. 263-286, 2012.

PROTHERICS. DigiFab ${ }^{\mathrm{TM}}$ Digoxin Immune Fab (Ovine) Clinical Product Monograph. Brentwood, 2001.

PULLEN, M. A. et al. Comparison of non-digitalis binding properties of digoxinspecific Fabs using direct binding methods. Journal of Immunological Methods, v. 336, n. 1, p. 235-241, 2008.

REUTERS. Glenveigh medical receives FDA fast track designation for development of preeclampsia drug. 2012.2 Disponível <http://www.reuters.com/article/idUS193020+12-Nov-2012+BW20121112>. Acesso em: 15 set. 2014. 
ROUET, R. et al. Expression of high-affinity human antibody fragments in bacteria. Nature Protocols, v. 7, n. 2, p. 364-373, 2012.

ROY, I.; GUPTA, M. N. Selectivity in affinity chromatography. In: HATTI-KAUL, R.; MATTIASSON, B. (Ed.). Isolation and purification of proteins. New York: Marcel Dekker, 2003. p. 57-94.

SCHUMANN, W.; FERREIRA, L. C. S. Production of recombinant proteins in Escherichia coli. Genetics and Molecular Biology, v. 27, n. 3, p. 442-453, 2004.

SHUKLA, A. A. et al. Strategies to addres aggregation during protein A chromatography. BioProcess Inetrnational, v. 3, n. 5, p. 36-45, 2005.

SIGMA-ALDRICH. Sigma Flag® E. coli expression system manual. EUA. 2005.

SILVA, G. J. JR. Cromatografia de proteínas guia teórico prático. Rio de Janeiro: Editora Interciência, 2004. 111 p.

SMITH, G. P. Filamentous fusion phage: novel expression vectors that display cloned antigens on the virion surface. Science, v. 228, n. 4705, p. 1315-1317, 1985.

SMITH, T. W.; BUTLER, V. P. JR; HABER, E. Characterization of antibodies of high affinity and specificity for the digitalis glycoside digoxin. Biochemistry, v. 9, p. 331337, 1970.

SPITALI, M.; GOTTSCHALK, U. (Ed.) Downstream processing of monoclonal antibody fragments. Process scale purification of antibodies, p. 349-372, 2009.

THORSTENSON, Y. R. et al. Leaderless polypeptides efficiently extracted from whole cells by osmotic shock. Journal of Bacteriology, v. 179, n. 17, p. 5333-5339, 1997.

WHEELWRIGHT, S. M. Protein purification design and scale up of downstream processing. New York: John Wiley \& Sons, 1991. 228 p.

WHITE, D. The physiology and biochemistry of prokaryotes. New York: Oxford University Press, 2007. 583 p.

WINTER, G. et al. Making antibodies by phage display technology. Annual Review of immunology, v. 12, p. 433-455, 1994.

YOON, S. H. et al. Secretory production of recombinant proteins in Escherichia coli. Recent Patents on Biotechnology, v. 4, p. 23-29, 2009.

ZAZERSKAYA, I. E. et al. Magnesium sulfate potentiates effect of Digifab on marinobufagenin-induced $\mathrm{Na} / \mathrm{K}-\mathrm{ATP}$ ase inhibition. American Journal of Hypertension, v. 26, n. 11, p. 1269-1272, 2013. 